NBER WORKING PAPER SERIES

\title{
GUARANTEED MARKETS AND CORPORATE SCIENTIFIC RESEARCH
}

\author{
Sharon Belenzon \\ Larisa C. Cioaca \\ Working Paper 28644 \\ http://www.nber.org/papers/w28644 \\ NATIONAL BUREAU OF ECONOMIC RESEARCH \\ 1050 Massachusetts Avenue \\ Cambridge, MA 02138 \\ April 2021, Revised January 2023
}

We thank Ashish Arora, Pierre Azoulay, Nick Bloom, Wesley Cohen, Mirko Draca, Florian Ederer, Elia Ferracuti, Dan Gross, Sharique Hasan, Sabrina Howell, David Hsu, Kenneth Huang, Peter Hull, Wonjoon Kim, Hong Luo, Fiona Murray, Andrea Patacconi, David Robinson, Yoko Shibuya, Andrew Shipilov, Steve Tadelis, John Van Reenen, and seminar participants at Berkeley, Columbia, Duke, ESMT, Georgia Tech, NBER, and Purdue for their helpful comments. We thank Lia Sheer, Dror Shvadron, Honggi Lee, Joyce Ma, Jungkyu Suh, and Hansen Zhang for their assistance with the data construction. The views expressed herein are those of the authors and do not necessarily reflect the views of the National Bureau of Economic Research.

NBER working papers are circulated for discussion and comment purposes. They have not been peer-reviewed or been subject to the review by the NBER Board of Directors that accompanies official NBER publications.

(C) 2021 by Sharon Belenzon and Larisa C. Cioaca. All rights reserved. Short sections of text, not to exceed two paragraphs, may be quoted without explicit permission provided that full credit, including (C) notice, is given to the source. 
Guaranteed Markets and Corporate Scientific Research

Sharon Belenzon and Larisa C. Cioaca

NBER Working Paper No. 28644

April 2021, Revised January 2023

JEL No. O3,O31,O32,O33,O38

\section{ABSTRACT}

To incentivize firms to develop innovative technologies, the U.S. government awards R\&D contracts that often carry an implicit promise of "guaranteed demand." That is, firms that demonstrate superior technological capabilities are often rewarded with noncompetitive downstream procurement contracts for the resulting products and services. This is a key difference between R\&D contracts and grants. Using newly assembled data on $\$ 5.9$ trillion in government procurement contracts from all federal agencies matched to U.S. publicly traded firms, we document a crowding-in effect of $R \& D$ contracts on upstream corporate $R \& D$ : firms co-invest with the government at the R\&D stage to increase their chances of landing lucrative downstream procurement contracts. We show that the crowding-in effect has weakened over time as the government has increasingly decoupled $\mathrm{R} \& \mathrm{D}$ contracts from downstream procurement. We discuss possible implications of this decoupling.

Sharon Belenzon

Fuqua School of Business

Duke University

100 Fuqua Drive

Durham, NC 27708

and NBER

sharon.belenzon@duke.edu

Larisa C. Cioaca

Fuqua School of Business

Duke University

100 Fuqua Drive

Durham 27708

larisa.cioaca@duke.edu 


\section{Introduction}

The government affects corporate innovation by subsidizing $R \& D$, directly through tax credits and grants, and indirectly through spillovers from government-funded R\&D and support for education. A less studied channel is the ability of the government to increase the private value of products and services resulting from upstream and downstream R\&D through government procurement (henceforth, "downstream procurement"). When private market incentives are weak, firms can still invest in $R \& D$ if this investment increases their chances of landing lucrative downstream procurement contracts with the government. In this paper, we examine the effect of government R\&D contracts on upstream and downstream corporate R\&D and show that the effect operates through the mechanism of guaranteed demand: rewarding firms that demonstrate technological superiority in R\&D races with noncompetitive downstream procurement.

Understanding how government procurement drives corporate innovation is important due to procurement's massive size, wide scope, and unique characteristics. Government procurement is large and growing. Between 1980 and 2015 (the last year of our sample), the U.S. government has more than doubled its annual procurement, from $\$ 207$ billion to $\$ 420$ billion. ${ }^{1}$ The 2015 amount includes $\$ 37.5$ billion in $\mathrm{R} \& \mathrm{D}$ contracts, as compared to $\$ 3.6$ billion in federal grants awarded to businesses that year. Moreover, government procurement touches many industries and encompasses much more than military acquisition, especially in recent decades. Between 1980 and 2015, the U.S. government has awarded contracts to firms in 351 industries, while the share of nonmilitary procurement dollars in all government procurement has risen from $40 \%$ in 1982 to $68 \%$ in 2015 .

Yet, despite its size and scope, government procurement has been understudied in the voluminous innovation literature. Existing work has advanced our understanding of how grants affect scientific research and technology development by individual researchers and small firms (e.g., Howell, 2017; Myers \& Lanahan, 2022; Wallsten, 2000). However, by focusing on R\&D subsidies, existing work has largely neglected the effect of demand-side policies on corporate R\&D. ${ }^{2} R \& D$ contracts and grants touch different types of firms, and in distinct ways, because they are fundamentally different in their objectives, requirements, and incentives for innovation. While grants are used to stimulate $R \& D$ activity that is in the public interest, $R \& D$ contracts are used only when the principal purpose is acquisition of products or services. Grants are a form of financial assistance. They typically have no precise timetables, only require best effort, and use advance payments. $R \& D$ contracts, on the other hand, are not "free money." They have schedules of milestones, require delivery of promised deliverables, and may use advance payments, but also progress and performance-based payments. ${ }^{3}$

The main difference between R\&D contracts and grants, however, lies in how they incentivize

\footnotetext{
${ }^{1}$ All dollar amounts in this paper are reported in constant 2012 dollars.

${ }^{2}$ A handful of prior studies focus on procurement contracts (e.g., Lichtenberg, 1988; Slavtchev \& Wiederhold, 2016). Yet, none of them systematically match federal contracts to American firms at scale, distinguish between upstream and downstream R\&D, and explore systematically the guaranteed demand mechanism behind the effect.

${ }^{3}$ Grants and R\&D contracts can also be compared in terms of intellectual property rights. While both grants and R\&D contracts fall under the patent rights provisions of the Bayh-Dole Act of 1980 and its extensions, R\&D contracts also fall under the data rights provisions prescribed in the Federal Acquisition Regulation (for civilian agencies) and the Defense Federal Acquisition Regulation (for the Department of Defense).
} 
innovation. While both subsidize R\&D (a supply-side effect), R\&D contracts also carry the implicit promise of future public demand (a demand-side effect). Unlike grants, R\&D contracts create knowledge that must be implemented in downstream procurement (Federal Acquisition Regulation Section 35.003 specifies that R\&D contracts "shall be used only when the principal purpose is the acquisition of supplies or services for the direct benefit or use of the Federal Government"). The need for implementation means that the government faces the challenge of designing incentives that will not only encourage innovation, but also overcome inefficiencies in knowledge implementation in downstream procurement. Such inefficiencies may arise when there is a high degree of complementarity between R\&D and production; the government faces contractual problems due to the transfer of tacit knowledge and asymmetric information (e.g., Bhattacharya, 2021; Che, Iossa, \& Rey, 2021); or firms face contractual problems due to incomplete contracts between R\&D specialists and downstream producers (e.g., Hart \& Moore, 1988, 1999). One way to overcome implementation inefficiencies is to award the downstream procurement contract automatically to the firm that successfully performs the R\&D (e.g., through a "single source" award), a mechanism we term guaranteed demand. Because downstream contracts are large and lucrative (on average, contractors in our sample receive $\$ 93$ million in downstream contracts per year, compared to $\$ 18$ million in R\&D contracts), firms should be willing to co-invest with the government to win the R\&D race and improve their chances of landing the downstream contract. This mechanism leads to a crowding-in effect of R\&D contracts on corporate innovation.

The acquisition of the Human Landing System (HLS) that will take people back to the Moon provides an example of how the government procures new technologies. In April 2020, the National Aeronautics and Space Administration (NASA) awarded a combined $\$ 1$ billion in R\&D contracts to SpaceX, Blue Origin, and Dynetics to begin development of the HLS during a 10-month base period. In April 2021, under budgetary pressures, NASA awarded a single $\$ 2.9$ billion R\&D contract to SpaceX to continue development of the HLS. Blue Origin and Dynetics protested this award with the Government Accountability Office, but lost. In July 2021, Blue Origin offered to cover up to $\$ 2$ billion in contract costs for a chance to remain in the HLS competition. ${ }^{4}$ Why did this forprofit company offer to co-invest in government R\&D? Because the co-investment would improve its chances of winning the R\&D competition, which all-but-guarantees Blue Origin billions of dollars in future downstream public demand for its lander technology. ${ }^{5}$

We estimate the effect of $R \& D$ contracts on corporate $R \& D$ expenditures, upstream $R \& D$ measured by scientific publications and employment of renowned and award-winning scientists, and downstream R\&D measured by patents. We extend the panel of 4,520 firms and 60,885 firm-year

\footnotetext{
${ }^{4}$ Blue Origin founder Jeff Bezos criticized NASA's decision to rely on a single company: "Instead of investing in two competing lunar landers as originally intended, the Agency chose to confer a multi-year, multi-billion-dollar head start to SpaceX. That decision broke the mold of NASA's successful commercial space programs by putting an end to meaningful competition for years to come." (Bezos, 2021)

${ }^{5}$ Mowery (2012) makes a similar argument that the procurement contract to supply semiconductor components for strategic missile guidance systems was the "prize" that incentivized Texas Instruments to develop the integrated circuit. While NASA did not respond to Blue Origin's offer, in March 2022 the agency announced plans for a second HLS solicitation - open to all U.S. companies except SpaceX - to meet the agency's future transportation needs.
} 
observations from Arora, Belenzon, and Sheer (2021) by adding data on $\$ 5.9$ trillion in procurement contracts and $\$ 19.2$ billion in grants awarded by dozens of federal agencies.

A key challenge in our analyses is dealing with the endogeneity of contracts (David, Hall, \& Toole, 2000). Common shocks can affect both government procurement and corporate R\&D. ${ }^{6}$ To mitigate this concern, we use variation in industry-level procurement, agency-level windfall funding resulting from the congressional appropriations process, and product-level procurement to predict firm-level R\&D contracts. We also exploit a quasi-natural experiment - the end of the Cold War, which triggered substantial reallocation in government contracts due to changes in national priorities, rather than technology or demand shocks - in an event study design.

With our newly assembled data and methodology we present three sets of results. First, we show that federal procurement is no longer dominated by the acquisition of military products and services. The share of procurement dollars awarded by the Department of Defense (DoD) in all federal procurement dollars has declined from a high of $86 \%$ in 1982 to $62 \%$ in 2015 . At the same time, the share of procurement dollars awarded for military products and services in all DoD procurement dollars has declined from $64 \%$ in 1980 to $45 \%$ in $2015 .{ }^{7}$ Taken together, these trends mean that nonmilitary procurement represented $49 \%$ of all procurement dollars awarded in 1982, but a much larger share of $72 \%$ in 2015 , as shown in Figure 1. Correspondingly, we find that federal procurement touches a broad set of R\&D-performing firms, not just military contractors.

Second, we show that R\&D contracts crowd-in upstream corporate R\&D. A $\$ 10$ million increase in $R \& D$ contracts increases company-funded $R \& D$ expenditures by $\$ 4.7$ million. More specifically, the $\$ 10$ million increase in R\&D contracts leads to a $3 \%$ increase in the number of publications authored by corporate scientists and to a $10 \%$ increase in the number of renowned scientists employed by the firm. However, we find no effect on downstream R\&D, as measured by patents.

We explore the guaranteed demand mechanism behind these results: that R\&D contracts crowdin company-funded investment in R\&D because they carry the implicit promise of future downstream procurement awarded without competition. This promise is unobserved in the federal procurement data, both ex ante (R\&D contracts do not explicitly include it) and ex post (noncompetitive downstream procurement contracts cannot be linked, at scale, to the specific R\&D contracts that led to them). Therefore, the guaranteed demand mechanism must be inferred indirectly by showing that the crowding-in effect is present when guaranteed demand is more salient, and absent when guaranteed demand is unlikely to be used. We expect a crowding-in effect when implementation costs are high. Consistent with this, we find a crowding-in effect for $\mathrm{R} \& \mathrm{D}$ that is associated with more scientific publications and the hiring of additional renowned scientists, but not with more patents. This type of upstream knowledge should be harder to implement, arguably making guaranteed demand more salient. Also, we expect a crowding-in effect on upstream R\&D when capturing returns

\footnotetext{
${ }^{6}$ If $\mathrm{R} \& \mathrm{D}$ contracts targeted firms that experience positive (negative) technology or demand shocks, the OLS estimates would be upward-biased (downward-biased).

${ }^{7}$ We classify DoD procurement as military or nonmilitary based on the Product and Service Codes Manual (in the case of R\&D contracts) and the Government-Wide Category Management Taxonomy (in the case of downstream procurement contracts).
} 


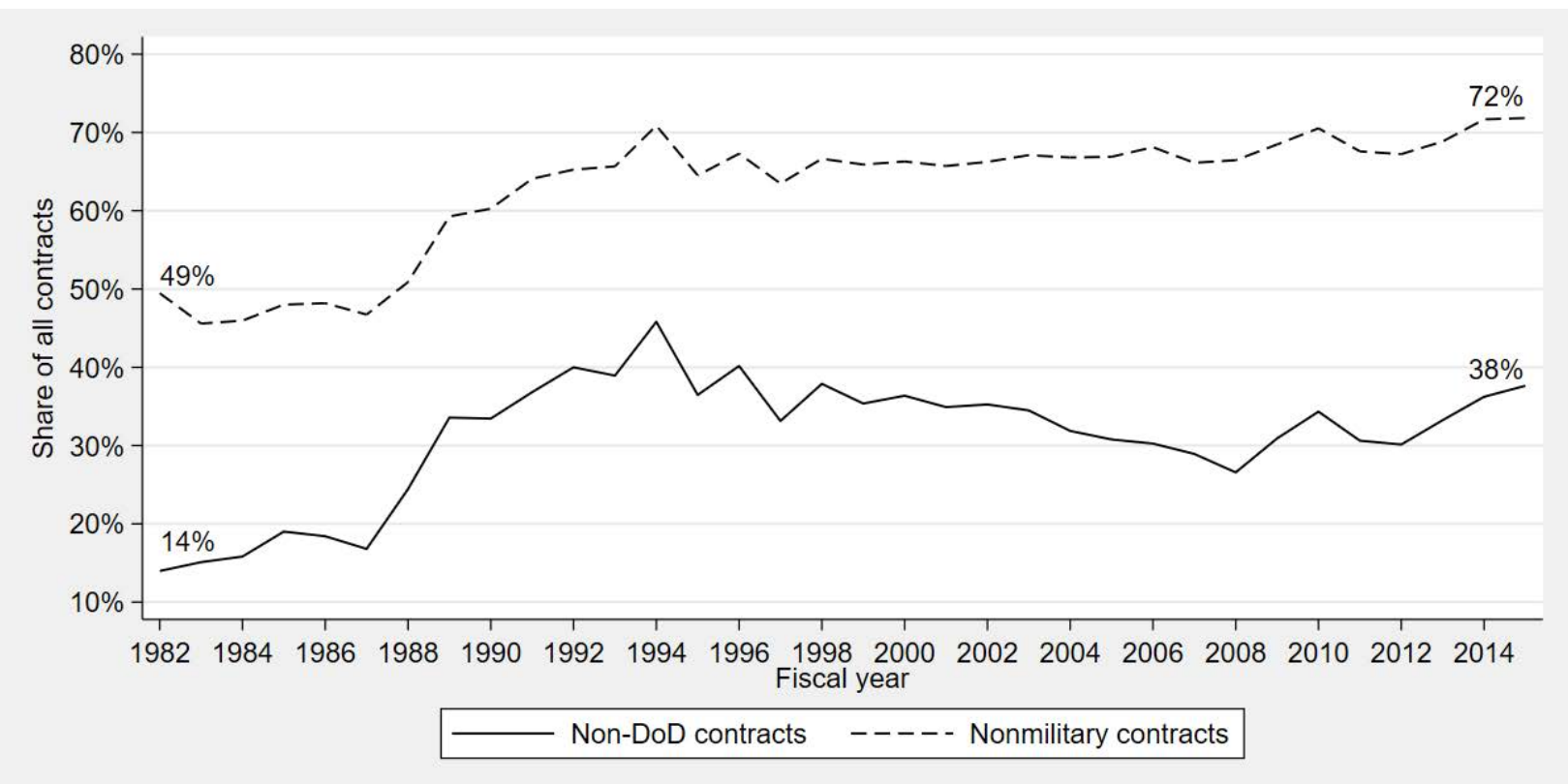

Figure 1: Share of Nonmilitary Procurement in All Contracts Over Time

This figure plots the shares of non-DoD contract dollars (solid line) and nonmilitary contract dollars (dotted line), respectively, in all contract dollars obligated by federal agencies to all recipients (not limited to our sample firms) over time. The classification of DoD contracts into military and nonmilitary is described in Appendix C.

in private markets is difficult. Weak market incentives for implementing upstream knowledge in commercial products can arise when commercial applications for new technologies lie far away into the future (Weiss, 2014), knowledge spills over to rivals (Arora, Belenzon, \& Sheer, 2021; Bloom, Schankerman, \& Van Reenen, 2013), and incomplete contracts and asymmetric information make markets for technology inefficient (Arrow, 1962; Edler \& Georghiou, 2007; Kremer, Levin, \& Snyder, 2020). Consistent with this argument, we find an effect of R\&D contracts on publications that are (i) not cited by the firm's own patents (consistent with limited downstream applications), (ii) cited by rival firms' patents (consistent with market-stealing due to spillovers to rivals), and (iii) not protected by the firm's own patents.

Our third set of results focuses on the weakening effect of $R \& D$ contracts on corporate innovation over time due to the decoupling of $R \& D$ contracts from downstream procurement and the potential implications of this decoupling. Policy reforms implemented in the 1980s and 1990s changed the nature and composition of federal procurement. The Federal Acquisition Streamlining Act of 1994 shifted procurement away from mission-focused technologies that met unique government specifications (which accounted for the majority of procurement dollars in the 1960s and 1970s) and toward commercial items and dual-use technologies that could be used in both military and commercial applications (Weiss, 2014). We document a rise in competitive procurement (a direct measure of guaranteed demand) and a larger allocation of contracts to firms that do not participate in scientific research, over time. These trends suggest that the government has increasingly decoupled R\&D races from downstream procurement, thus weakening the implicit promise of guaranteed demand. 
We also present evidence suggesting that the implementation of $\mathrm{R} \& \mathrm{D}$ contracts in downstream procurement might have become more difficult due to this decoupling. We document (i) a negative relationship between subcontracting and competitive contracts: the share of contracts that are subcontracted to other firms in total contracts is lower in industries with a higher share of competitive contracts. This pattern is inconsistent with efficient decoupling, which predicts more subcontracting between specialised upstream and downstream firms when downstream contracts are awarded competitively. (ii) There is a larger allocation of $R \& D$ contract dollars to research projects that are further from implementation. And, (iii) we find a substantial rise in contractual deobligations, our most direct measure of failed implementation. These trends suggest that decoupling R\&D races from downstream procurement may have adversely affected project success.

With the above findings, we make two main contributions to the literature on the economics of innovation. First, we help explain why corporations are withdrawing from scientific research. In recent decades, the composition of corporate $\mathrm{R} \& \mathrm{D}$ has shifted away from research and toward development. The share of research dollars in business R\&D has dropped from a high of $31 \%$ in 1986 to $20 \%$ in $2015 .{ }^{8}$ Concurrently, adjusting for firm size, the annual number of corporate publications has declined (Arora, Belenzon, \& Sheer, 2021) and the market value attributed to firm scientific capabilities (i.e., the "shadow price" of scientific publications) has fallen (Arora, Belenzon, \& Patacconi, 2018). By decoupling R\&D races from downstream procurement, the government has potentially amplified the withdrawal of corporations from scientific research through the weakening of the crowding-in effect of $R \& D$ contracts on upstream corporate $R \& D$.

Second, we add to the literature on how government policy affects innovation (e.g., Bloom, Van Reenen, \& Williams, 2019; Edler \& Georghiou, 2007; Mowery, 2010; Rogerson, 1989; Slavtchev \& Wiederhold, 2016). Our results show that procurement policy - an area that has not received as much scholarly attention as public funding and tax policies - should also be considered a national innovation policy. Legislative and executive actions - as old as the Buy American Act of 1933 and as recent as President Biden's Executive Order on Ensuring the Future Is Made in All of America by All of America's Workers, signed on January 25, 2021-have used downstream procurement to boost domestic economic activity and support targeted geographies or industries. To the best of our knowledge, this paper is the first to demonstrate the effect of government procurement on upstream and downstream corporate R\&D. This link between government procurement and corporate R\&D investment is one important way in which demand-side policies are different from supply-side policies (e.g., grants and tax subsidies).

\section{Related Literature}

A voluminous literature examines how the government affects corporate R\&D through tax credits (e.g., Bloom, Griffith, \& Van Reenen, 2002), grants (e.g., Azoulay, Graff Zivin, Li, \& Sampat, 2019; Howell, 2017; Packalen \& Bhattacharya, 2020; Wallsten, 2000), and spillovers from federal

\footnotetext{
${ }^{8}$ Data are from Tables 2, 3, and 4 of the National Patterns of R\&D Resources: 2017-2018 series available at https://ncses.nsf .gov/pubs/nsf 20307.
} 
laboratories and universities (e.g., Adams, Chiang, \& Jensen, 2003; Cohen, Nelson, \& Walsh, 2002). Government procurement is also the subject of (mostly) theoretical studies on optimal procurement mechanism design (e.g., Arve \& Martimort, 2016; Bhattacharya, 2021; Che \& Gale, 2003; Che et al., 2021; Decarolis, 2014; Riordan \& Sappington, 1989), competition in contracting (e.g., Kang \& Miller, 2022), and waste/efficiency in contracting (e.g., Bandiera, Prat, \& Valletti, 2009; Liebman \& Mahoney, 2017). Only a handful of studies empirically examine procurement contracts (e.g., Lichtenberg, 1988; Moretti, Steinwender, \& Van Reenen, 2021; Slavtchev \& Wiederhold, 2016). These papers do not estimate the separate effect of $R \& D$ contracts on upstream and downstream corporate R\&D or systematically test the guaranteed demand mechanism.

Most prior studies focus on funding from the Small Business Innovation Research (SBIR) program or the National Institutes of Health (NIH). ${ }^{9}$ For example, research covering small firms shows that SBIR awards crowd out company-funded R\&D expenditures (Wallsten, 2000). Yet, early stage SBIR awards also increase forward citation-weighted patents, especially for financially constrained small firms (Howell, 2017). In a recent paper, Howell, Rathje, Van Reenen, and Wong (2021) evaluate policy reforms aimed at changing how the U.S. Air Force SBIR program procures new technologies from small firms. They compare the conventional approach to R\&D contracting, where firms respond to solicitations for specific research topics, with an open approach that allows firms to submit proposals on any topic. Using comprehensive data on proposals submitted by firms during 2017-2019 and a regression discontinuity design, they find that winning an open-topic R\&D contract increases the likelihood of raising venture capital funding and improves the chances of winning a subsequent non-SBIR contract from the DoD. This finding supports the premise that winning $R \& D$ races is a pathway to subsequent downstream procurement.

Azoulay et al. (2019) show that National Institutes of Health (NIH) grants have a positive effect on corporate $\mathrm{R} \& \mathrm{D}$. An additional $\$ 10$ million in NIH grant funding for a research area generates 2.3 additional biopharmaceutical firm patents in that area, or roughly one patent for every 2-3 NIH grants. This result underscores that patents are an effective tool for appropriating returns from corporate R\&D in the biopharmaceutical industry. Yet, the NIH's tendency to fund new ideas has declined over time. Between the 1990s and the 2000s, grant support shifted from "edge science" toward more traditional science (Packalen \& Bhattacharya, 2020).

A few studies examine procurement contracts and are more closely related to our paper. Lichtenberg (1988) investigates the effect of procurement contracts on firm R\&D expenditures using a panel of 169 U.S. contractors during 1979-1984. He estimates that a $\$ 1$ increase in competitive procurement (including both $R \& D$ and non-R\&D contracts) increases company-funded R\&D expenditures by $\$ 0.54$, and suggests the reason why is that winning contractors are almost guaranteed to receive much larger follow-on noncompetitive contracts.

Slavtchev and Wiederhold (2016) study how the technological intensity of downstream procure-

\footnotetext{
${ }^{9}$ The SBIR program includes three phases, but only Phase I and II are funded through SBIR grants or contracts, depending on the participating agency (see https://beta.www.sbir.gov/participating-agencies). Phase III focuses on commercialization and, in some agencies, may include non-SBIR funded R\&D or downstream procurement contracts.
} 
ment (not including $R \& D$ contracts) affects private $R \& D$ expenditures using a panel of U.S. states during 1999-2009. They estimate that each procurement dollar that the government shifts from low-tech industries to high-tech industries induces an additional $\$ 0.21$ in private $R \& D$ expenditures. This crowding-in effect does not result from an increase in overall public demand, but rather from an increase in high-tech public demand. This suggests that the government can incentivize private R\&D investment by changing the composition of its procurement.

Moretti et al. (2021) study the effect of government-funded R\&D on private R\&D investment using industry-level data from OECD countries and firm-level data from France during 1980-2015. They also find a crowding-in effect, whereby increases in government-funded R\&D subsidies (including both grants and $\mathrm{R} \& \mathrm{D}$ contracts) for an industry or firm drive additional private $\mathrm{R} \& \mathrm{D}$ investment in that industry or firm. In their analyses of 12,539 French firms, they use industry-level defense $R \& D$ subsidies to instrument for public R\&D funding received by a focal firm. At the mean values of public and private $R \& D$ in France, they estimate that a $€ 1$ increase in government-funded R\&D generates $€ 0.85$ of additional corporate $R \& D$.

Our work diverges from previous studies in several important ways. First, we examine the effect of R\&D contracts separately on upstream corporate R\&D (scientific research or "R") and downstream corporate R\&D (technology development or "D") and systematically explore the guaranteed demand mechanism behind the effect. Second, we make progress on data and identification. We match contracts from dozens of agencies to thousands of R\&D-performing American firms and their subsidiaries over several decades. We use aggregate industry-level contracts to predict firm-level contracts, similar to Moretti et al. (2021). But we also present causal evidence that exploits changes in procurement driven by geopolitical, rather than technological or demand, forces. Third, to our knowledge, we are first to analyze how the nature and composition of government procurement has changed over the past several decades. Documenting these changes is important for understanding the implications of procurement policy reforms implemented throughout the 1980s and 1990s.

\section{Background on Government Procurement}

The U.S. government is the world's largest customer, procuring products and services worth $9.3 \%$ of the country's GDP in 2015. ${ }^{10}$ The typical procurement process includes an agency identifying the products and services it needs, determining the best method for purchasing them, and carrying out the acquisition in accordance with the Federal Acquisition Regulation (FAR). ${ }^{11}$ A more detailed discussion of the federal procurement process is included in Online Appendix A.

To understand the relevance of government procurement to corporate innovation, we must first understand which agencies buy, what they buy, from whom they buy, and how they use R\&D contracts to buy new technologies. The distribution of contracts by awarding agency is highly skewed. The DoD accounts for $69 \%$ of all contract dollars awarded during 1980-2015, while the Department of Energy (DoE), NASA, General Services Administration (GSA), and Health and

\footnotetext{
${ }^{10}$ Data are from Table 9.1 of OECD's Government at a Glance 2017 report.

11“Agency" means either a department or an independent agency, commission, or other U.S. government entity.
} 
Human Services (HHS) together account for another 16\% (see Table B1). Even within the DoD, there is significant heterogeneity in the size and composition of contracts by subagency. For example, the Air Force, Navy, and Army each awarded more than $\$ 2$ trillion in contracts between 1980 and 2015. Of those dollars, 79-90\% were awarded for downstream procurement. Conversely, the Defense Advanced Research Projects Agency (DARPA) awarded less than $\$ 14$ billion in contracts, of which $91 \%$ were for $R \& D$ services. As a result, the military subagencies were in the position to guarantee demand, while DARPA was not. ${ }^{12}$

Despite the powerful position of the DoD, government procurement is no longer dominated by military products and services. The share of procurement dollars awarded by the DoD in all federal procurement dollars has declined from a high of $86 \%$ in 1982 to $62 \%$ in 2015 . Moreover, the DoD itself is increasingly procuring commercially available and dual-use products and services. The share of military procurement dollars in all DoD procurement dollars has declined from $64 \%$ in 1980 to $45 \%$ in 2015 . Combined, these trends have shifted federal procurement decidedly in favor of nonmilitary products and services, as already shown in Figure 1.

Government procurement touches a broad set of industries and firms. Between 1980 and 2015, federal agencies awarded contracts to firms in 351 industries (identified by three-digit SIC code), including 21 industries that received more than $\$ 100$ billion each, 54 that received $\$ 10-99$ billion, and 58 that received $\$ 1-9$ billion. Over the same period, 10 industries received more than $\$ 1$ billion in $R \& D$ contracts each. ${ }^{13}$ These R\&D-intensive industries received a combined $\$ 541$ billion in R\&D contracts and $\$ 2.8$ trillion in downstream procurement contracts during 1980-2015.

In this paper, we focus on the effect of $R \& D$ contracts because awarding $R \& D$ contracts is how federal agencies manifest public demand for new technologies. Indeed, the Federal Acquisition Regulation (FAR) explicitly states that R\&D contracts are used to acquire products and services when the work, methods, and probabilities of success cannot be specified in advance. ${ }^{14}$ As shown in Figure $2, \mathrm{R} \& \mathrm{D}$ contracts represent a significant public investment in innovation. While R\&D contracts (solid line) are comparable in value to the $\mathrm{R} \& \mathrm{D}$ performed by the federal sector (intramurally and in federally-funded research and development centers, dashed line), they are an order of magnitude larger than the federal grants awarded to businesses (dotted line). ${ }^{15}$

\footnotetext{
${ }^{12}$ DARPA is the DoD's central R\&D organization, established in 1958 "to make pivotal investments in breakthrough technologies for national security." Unlike other DoD subagencies, DARPA focuses on R\&D projects that expand the frontiers of science and technology beyond immediate military requirements. It is independent of other military subagencies and reports directly to senior DoD management.

${ }^{13}$ While the top 10 was dominated by Aircraft and Parts (SIC 372), it also included Space Research and Technology (SIC 966), Guided Missiles and Space Vehicles and Parts (SIC 376), Research, Development, and Testing Services (SIC Code 873), Engineering, Architectural, and Surveying (SIC 871), Miscellaneous Business Services (SIC 738), Search, Detection, Navigation, Guidance, Aeronautical, and Nautical Systems, Instruments, and Equipment (SIC 381), Miscellaneous Services (SIC 899), Computer Programming, Data Processing, and other Computer Related Services (SIC 737), and Management and Public Relations Services (SIC 874).

${ }^{14}$ FAR Section 35.003 notes that R\&D contracts "shall be used only when the principal purpose is the acquisition of supplies or services for the direct benefit or use of the Federal Government." FAR Section 35.002 adds that, "unlike contracts for supplies and services, most R\&D contracts are directed toward objectives for which the work or methods cannot be precisely described in advance. It is difficult to judge the probabilities of success or required effort for technical approaches, some of which offer little or no early assurance of full success."

${ }^{15}$ The visible spike in federal grants awarded to businesses in 2010 is the result of a significant increase in DOE
} 


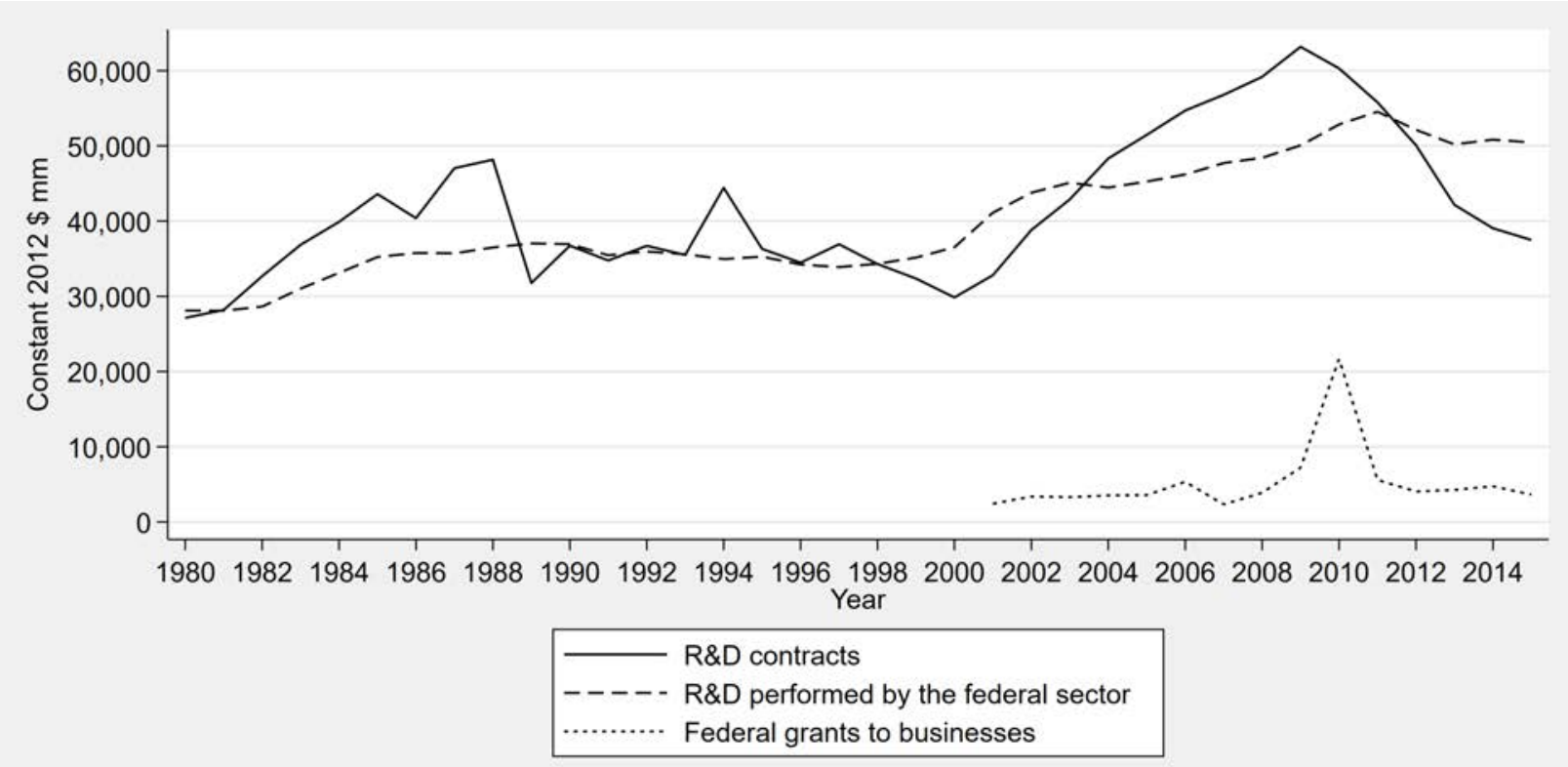

Figure 2: R\&D Contracts, R\&D Performed by the Federal Sector, and Federal Grants to Businesses

This figure compares R\&D contracts (solid line), R\&D performed by the federal sector (dashed line), and federal grants awarded to businesses (dotted line) over time. Federal sector data are from Table 2 of the National Patterns of R\&D Resources: 2017-2018 series available at https://ncses.nsf.gov/pubs/nsf20307. Federal grants to businesses are presented from 2001, the first year of comprehensive federal grant coverage in USAspending.gov.

\section{Data}

We combine data from four primary sources: (i) corporate R\&D data, including matched patents and academic publications (Arora, Belenzon, \& Sheer, 2021); (ii) renowned scientist biographical data from the American Men \& Women of Science (AMWS) directory; (iii) government procurement data reported to the Federal Procurement Data System (FPDS); and (iv) government grant data reported to the Treasury DATA Act Broker. Our data construction work is summarized below and detailed in Online Appendix B.

\subsection{R\&D Expenditures, Publications, and Patents}

We extend the panel from Arora, Belenzon, and Sheer (2021) by matching firms to federal procurement contracts awarded during fiscal years 1980-2015 and federal grants awarded during fiscal years 2001-2015. ${ }^{16}$ Because the firm panel from Arora, Belenzon, and Sheer (2021) accounts for changes in company names and ownership structures over time (e.g., due to mergers, acquisitions, or spinoffs), our data allow us to construct accurate contract and grant flows in a long panel.

Our sample includes 4,520 publicly traded firms headquartered in the U.S. that had (i) at least one year of reported R\&D expenditures during 1980-2015, (ii) at least one granted patent during

grants associated with the American Recovery and Reinvestment Act.

${ }^{16}$ We focus on "prime" contracts and grants awarded to firms that work directly with the government. 
1980-2015, and (iii) at least three years of consecutive financial records from their first granted patent. We use data on firm accounting measures (e.g., sales and R\&D expenditures sourced from Standard \& Poor's Compustat North America), publications (sourced from Clarivate's Web of Science), and patents (sourced from the European Patent Office's PATSTAT database). We measure firms' upstream R\&D using publications authored by corporate scientists and employment of renowned scientists, and downstream R\&D using granted patents (similar to Arora et al., 2018; Arora, Belenzon, \& Sheer, 2021). Our variable construction work is detailed in Online Appendix C.

\subsection{Renowned Scientists}

We collect biographical information from AMWS, a directory of renowned North American scientists in the physical, biological, and related sciences. Over the course of 39 editions published between 1906 and 2021, AMWS has profiled more than 300,000 people, including such information as field of specialty, education, professional experience, memberships, research information, and contact information. We match all records that appear in AMWS's digital editions separately to account for deceased scientists that are dropped from recent editions (yet, once identified, AMWS provides a full employment history for the scientist). We match the names of scientists' employers to the names of subsidiaries and their ultimate owners from our firm panel. We identify 20,552 renowned scientists who worked for 1,727 firms in our panel during 1980-2015. We aggregate renowned scientists at the firm-year level by counting the number of scientists employed by an ultimate owner and its subsidiaries each year. Moreover, AMWS collects information on major awards won by scientists, which we incorporate in our analysis of award-winning scientists employed by our sample firms.

The two measures of corporate science - publications and renowned scientists employed - are highly correlated. ${ }^{17}$ However, each measure captures imperfectly the scientific activities of the firm. Table 1 shows that $49 \%$ of the firms that publish do not employ renowned scientists, while $10 \%$ of the firms that employ renowned scientists do not publish. This suggests that using both measures of upstream R\&D in our analyses is warranted.

Table 1: Cross Tabulation of Measures of Corporate Science

(1) (2)

Do not employ scientists

Employ scientists

Total

\begin{tabular}{lccc}
\hline Do not publish & 1,325 & 172 & 1,497 \\
Publish & 1,468 & 1,555 & 3,023 \\
Total & 2,793 & 1,727 & 4,520 \\
\hline
\end{tabular}

Notes: This table provides a cross tabulation of measures of corporate science for the 4,520 firms in our sample. The unit of analysis is a firm.

\footnotetext{
${ }^{17}$ The pairwise correlation between corporate publications and renowned scientists in a firm-year is 0.69 .
} 


\subsection{Federal Procurement Contracts}

We collect all federal procurement contracts and indefinite delivery vehicles (henceforth, "contracts") reported via two government websites, SAM.gov (for 1980-2000 data) and USAspending.gov (for 2001-2015 data). ${ }^{18}$ We match the names of contract recipient firms and their parent companies to the names of subsidiaries and their ultimate owners from our firm panel (see Online Appendix B for details). We identify 8.6 million unique contracts totalling $\$ 5.9$ trillion awarded by 72 federal agencies to 2,590 R\&D-performing, publicly traded U.S. firms (henceforth, "contractors"). These matched contracts represent $47 \%$ of the value of all contracts awarded to all recipients during 1980-2015. ${ }^{19}$ Contractors typically receive multiple contracts per year. We aggregate the value of contracts at the firm-year level by summing up all the contracts and modifications awarded to an ultimate owner and its subsidiaries each fiscal year.

Agencies use a four-digit Product or service code to describe the principal product or service purchased in each transaction. ${ }^{20}$ We use this classification system to separate $R \& D$ contracts from non-RED contracts (i.e., downstream procurement). We also use crosswalks between product and service codes, the North American Industry Classification System (NAICS), and the Standard Industrial Classification (SIC) - available from the Defense Logistics Agency and the Census Bureau-to identify the primary four-digit industry (SIC4) for each transaction. This allows us to calculate the aggregate value of procurement contracts for each industry-year, which is essential for constructing our instrumental variables.

The Federal Acquisition Streamlining Act of 1994 establishes a statutory preference for procuring commercially available products and services to the maximum extent practicable. As a result, agencies acquire products and services as diverse as computers, transportation, and medicine using simplified requirements and streamlined practices intended to resemble those used in commercial markets (e.g., exempting contractors from the requirement to submit certified cost or pricing data). We use the Commercial items acquisition procedures field to divide non-R\&D contracts into commercial contracts and noncommercial contracts. ${ }^{21}$ This allows us to explore how the effect of R\&D

\footnotetext{
${ }^{18} \mathrm{An}$ indefinite delivery vehicle (IDV) is a type of contract in which the government agrees to buy a product or service from a certain vendor for a certain quantity or time frame. The government does not obligate funding when the contract is signed, but rather when a supply or service order is placed. Examples of IDVs include blanket purchase agreements, government-wide acquisition contracts, and indefinite delivery contracts.

${ }^{19}$ The $\$ 7.5$ trillion in unmatched contracts were awarded by the DoD (62\% of unmatched contract value), DoE (9\%), GSA (3\%), NASA (3\%), HHS (3\%) and other agencies (20\%) to a broad range of industries, led by Aircraft and Parts (SIC 372, 7\%), Computer Programming, Data Processing, and Other Computer Related Services (SIC 737, 4\%), and Professional and Commercial Equipment and Supplies (SIC 504, 3\%). These contracts covered a broad range of products and services, led by Operation of Structures and Facilities (8\% of unmatched contract value; $6 \%$ for Operation of Government-Owned Contractor-Operated R\&D Facilities), Support- Professional (7\%), Construction of Structures and Facilities (5\%), Fuels, Lubricants, Oils, and Waxes (5\%), and Information Technology and Telecommunications (4\%). Among the top recipients were nonprofit organizations (e.g., The Regents of the University of California, California Institute of Technology, Battelle Memorial Institute), foreign firms (e.g., S.N.C. Scionti, BAE Systems), and other public entities (e.g., the State of California).

${ }^{20}$ See Appendix Tables C3 and C4 for the 24 letter codes used to classify service categories and the 78 two-digit numerical codes used to classify product groups, respectively.

${ }^{21}$ We do not break down R\&D contracts into commercial and noncommercial because the former would represent less than $1 \%$ of the total value of $R \& D$ contracts awarded to our sample of firms.
} 
contracts has changed over time as the government has increased procurement of technologies with existing commercial applications and decreased procurement of new technologies designed to meet unique agency specifications.

\subsection{Guaranteed Demand}

Guaranteed demand refers to rewarding firms that demonstrate technological superiority in R\&D races with noncompetitive downstream procurement contracts. While federal agencies are generally required to use full and open competition in procurement, the Competition in Contracting Act of 1984 authorizes noncompetitive contracting under a limited number of exceptions. Notable among the exceptions are follow-on contracts for the continued development or production of a major system or highly specialized equipment, or (in the case of the DoD, NASA, and the Coast Guard) for the continued provision of highly specialized services. ${ }^{22}$ This legal framework allows the government to couple $R \& D$ races with downstream procurement by awarding follow-on contracts without competition. We use the Extent competed field to distinguish contracts that were awarded competitively from those awarded noncompetitively. This allows us to classify industries with top quartile shares of noncompetitive downstream procurement contracts in all downstream procurement contracts (relative to other industries' shares in the same fiscal year) as industries with high guaranteed demand. Remaining industries have low guaranteed demand.

\subsection{Federal Grants}

We collect all the financial assistance awards (including grants, cooperative agreements, and direct payments, but not loans or insurance; henceforth, "grants") awarded by all federal agencies during 2001-2015 from USAspending.gov. ${ }^{23}$ We match the names of grantees to our firm panel. We identify 456 firms that receive a total of $\$ 19.2$ billion in grants from 25 federal agencies during 2001-2015. Similar to contractors, grant recipients typically receive multiple grants per year. We aggregate the value of grants at the firm-year level by summing up all the grants and modifications awarded to an ultimate owner and its subsidiaries each fiscal year. This allows us to control for government funding when we test the guaranteed demand mechanism. ${ }^{24}$

\footnotetext{
${ }^{22}$ FAR Section 6.302 limits these exceptions to circumstances when awarding follow-on contracts to any other source would likely result in (i) substantial duplication of cost that is not expected to be recovered through competition or (ii) unacceptable delays in fulfilling the agency's requirements.

${ }^{23}$ We do not include grants for fiscal years 1980-2000 because the data are only available for select agencies (e.g., National Science Foundation and National Institutes of Health).

${ }^{24}$ The distribution of grants by awarding agency is highly skewed. The DoE accounts for $40 \%$ of all grants awarded to sample firms during 2001-2015, followed by the DoD (14\%), Department of Agriculture (9\%), HHS (9\%), and State Department (8\%). By dollar value, $55 \%$ of awards are cooperative agreements, $33 \%$ are block, formula, or project grants, and $12 \%$ are direct payments. Grantees receive an average of $\$ 2$ million in grants per year (with a median of less than $\$ 0.1$ million).
} 


\subsection{Descriptive Statistics}

Table 2 presents descriptive statistics for the main variables used in our econometric analyses. Approximately $71 \%$ of firms perform scientific research (i.e., employ at least one renowned scientist or have at least one scholarly publication). These firms employ an average of 5 renowned scientists and publish an average of 17 publications per year. By construction, all firms have at least one patent during the sample period. Firms produce an average of 22 patents per year.

Procurement touches a broad set of R\&D-performing firms. In our sample, $1 \%$ of firms are pure military contractors, $29 \%$ supply both military and nonmilitary needs, $27 \%$ are pure nonmilitary contractors, and $43 \%$ are noncontractors. Combined, $57 \%$ of firms receive at least one contract during 1980-2015, 23\% receive at least one R\&D contract during 1980-2015, and $10 \%$ receive at least one federal grant during 2001-2015.

Table 2: Descriptive Statistics

\begin{tabular}{|c|c|c|c|c|c|c|}
\hline & (1) & $(2)$ & (3) & \multicolumn{2}{|c|}{ Distribution } & $n^{(6)}$ \\
\hline & Obs. & Mean & Std. dev. & 10 th & 50 th & 90th \\
\hline R\&D expenditures $(\$ \mathrm{~mm})$ & 54,238 & 111 & 557.2 & 0.5 & 10.0 & 147.4 \\
\hline Renowned scientists & 47,329 & 5 & 33.5 & 0.0 & 0.0 & 6.0 \\
\hline Publications & 47,329 & 17 & 94.9 & 0.0 & 1.0 & 19.5 \\
\hline Patents & 60,885 & 22 & 132.2 & 0.0 & 1.0 & 31.5 \\
\hline All contracts $(\$ \mathrm{~mm})$ & 41,631 & 111 & $1,277.9$ & 0.0 & 0.1 & 26.5 \\
\hline R\&D contracts $(\$ \mathrm{~mm})$ & 41,631 & 18 & 274.6 & 0.0 & 0.0 & 0.6 \\
\hline Non-R\&D contracts $(\$ \mathrm{~mm})$ & 41,631 & 93 & $1,038.4$ & 0.0 & 0.1 & 23.6 \\
\hline Commercial contracts $(\$ \mathrm{~mm})$ & 27,197 & 13 & 107.0 & 0.0 & 0.0 & 4.2 \\
\hline Noncommercial contracts $(\$ \mathrm{~mm})$ & 27,197 & 93 & $1,157.0$ & 0.0 & 0.0 & 10.6 \\
\hline All grants $(\$ \mathrm{~mm})$ & 5,495 & 2 & 21.1 & 0.0 & 0.0 & 2.6 \\
\hline Sales $(\$ \mathrm{~mm})$ & 60,557 & 2,603 & $12,747.3$ & 2.9 & 146.3 & $4,334.6$ \\
\hline R\&D stock $(\$ \mathrm{~mm})$ & 60,885 & 428 & $2,495.1$ & 0.6 & 26.0 & 483.3 \\
\hline All contracts / Sales (\%) & 41,063 & 3 & 11.1 & 0.0 & 0.0 & 4.5 \\
\hline R\&D contr. / (R\&D contr. + R\&D exp.) (\%) & 37,309 & 4 & 14.2 & 0.0 & 0.0 & 2.4 \\
\hline
\end{tabular}

Notes: This table presents descriptive statistics for the main variables used in the econometric analyses. The unit of analysis is a firm-year. Renowned scientists and publications are summarized for firms that perform scientific research, while contract statistics are only provided for contractors. Commercial and noncommercial contracts are only summarized for fiscal years 1995-2015. Grant statistics are only provided for fiscal years 2001-2015 and firms that receive at least one grant during this period.

Contractors are awarded an average of $\$ 111$ million in contracts per year. Of those dollars, an average of $\$ 18$ million are for R\&D services, which is almost an order of magnitude larger than the annual grants received by grant recipient firms. On average, contractors receive contracts from 6 federal agencies (with a median of 4 agencies). Consistent with the guaranteed demand mechanism, $84 \%$ of sample firms that win an R\&D contract subsequently receive at least one noncompetitive downstream procurement contract during their remaining years in our sample. Among firms that never win an R\&D contract, only $35 \%$ receive at least one noncompetitive downstream procurement contract during their years in our sample.

On average, federal contracts represent $3 \%$ of total firm sales, while R\&D contracts represent 
$4 \%$ of total government-funded and firm-funded R\&D. However, 77 sample firms get at least $25 \%$ of total sales from the government, while 23 get at least $50 \%$. These 23 firms are larger $(\$ 6,059$ million in annual sales), receive more $R \& D$ contracts ( $\$ 728$ million per year), publish more (49 publications per year), and patent more (28 patents per year) compared to the average sample firm. ${ }^{25}$

There is substantial heterogeneity in contracts by awarding agency (see Appendix Table E10). The average value of an $R \& D$ contract ranges from $\$ 8,362$ for the Federal Maritime Commission to $\$ 15,999,149$ for the U.S. Agency for International Development. An R\&D contract from the DoD, NASA, and DoE is worth $\$ 4.8$ million, $\$ 7.3$ million, and $\$ 3$ million, respectively. Importantly, these agencies award noncompetitive downstream procurement contracts that are larger than the average downstream procurement contract. Moreover, agencies that award a significant share of basic and applied R\&D contracts in all contracts (which suggests high demand for innovative technologies) also award a significant share of downstream procurement contracts without competition, as can be seen in Appendix Figure E3. This pattern is consistent with the view that firms have strong incentives to win $R \& D$ races as a pathway to public demand. ${ }^{26}$

There is also heterogeneity in the characteristics of $R \& D$ contractors working for different agencies (see Appendix Table E11). Firms that win R\&D contracts from the Department of Commerce (DoC) tend to publish more than other R\&D contractors. Firms that win large R\&D contracts from one agency tend to also win large $R \& D$ contracts from other agencies (see Appendix Tables E12 and E13). Regardless of R\&D contract size, defense R\&D contractors tend to work also for NASA (see Appendix Table E14). Firms that are R\&D contractors for a non-defense agency tend to also be defense R\&D contractors. At the high end, $93 \%$ of DoC R\&D contractors are defense R\&D contractors, while at the low end, $52 \%$ of HHS R\&D contractors are also defense R\&D contractors.

Our sample is drawn from a wide distribution of industries (see Appendix Table F15). The two-digit industries (SIC2) most represented are Chemicals (796 firms), Electronic Equipment (680 firms), and Instruments (672 firms). We classify those industries into five main groups: Chemicals, Electronics, Instruments, Business services, and Others (see Appendix Table F16). The largest average annual $R \& D$ contracts are in the Others group ( $\$ 45$ million), while the smallest are in Chemicals (\$1 million, see Appendix Table F17). Among contractors, the number of publications per $\$ 1$ million in contracts ranges from a low of 0.05 in the Others group to a high of 3.95 in Chemicals. Industry groups with the lowest and highest numbers of patents per $\$ 1$ million in contracts are Instruments and Chemicals, respectively. Among R\&D contractors, the average number of publications per $\$ 1$ million in R\&D contracts ranges from a low of 0.29 in the Others group to a high of 63.45 in Drugs. Meanwhile, the average number of patents per $\$ 1$ million in $R \& D$ contracts ranges from a low of 0.51 in Instruments to a high of 37.39 in Chemicals.

The composition of government contracts varies by main industry and over time. In 1994, just

\footnotetext{
${ }^{25}$ The 23 firms operate in the Instruments (7 firms), Business services (4 firms), Chemicals (2 firms), Electronics (2 firms), and other main industries (8 firms).

${ }^{26}$ The use of demand pull for innovation is not unique to the U.S. government. For example, the UK Government's Environmental Innovation Advisory Group introduced the Forward Commitment Procurement concept in the mid2000 s to provide "the incentive, confidence and momentum for suppliers to invest and deliver innovative solutions" to environmental challenges (U.K. Department for Business, Innovation \& Skills, 2011).
} 
before the passage of the Federal Acquisition Streamlining Act, the industries with the highest share of R\&D contracts in all contracts were the Others group (35\%) and Instruments (23\%). In 2015, the industries with the highest share of commercial contracts in all contracts were Chemicals $(76 \%)$ and Electronics (38\%).

Table 3 presents mean comparison tests between the 1,019 R\&D contractors and the other 3,501 firms in our sample. On average, R\&D contractors are much larger ( $\$ 6$ billion vs. less than $\$ 1$ billion in annual sales). They invest more in R\&D ( $\$ 265$ million vs. $\$ 33$ million per year), but have lower R\&D intensity ( $\$ 1.4$ million vs. $\$ 5.9$ million in $R \& D$ expenditures per $\$ 1$ million in sales). In addition, $R \& D$ contractors perform more scientific research ( 0.4 vs. 0.3 annual publications per $\$ 1$ million in R\&D expenditures), and about half as much downstream development (0.6 vs. 1.2 patents per $\$ 1$ million in $R \& D$ expenditures). R\&D contractors receive more grant funding ( $\$ 0.9$ million vs. $\$ 0.1$ million per year). These differences persist when comparing R\&D contractors with other firms within the same industry (see Appendix Table F18).

Table 3: R\&D CONTRACTORS Vs. Other Firms

\begin{tabular}{|c|c|c|c|c|c|c|}
\hline & (1) & $(2)$ & $(3)$ & $(4)$ & $(5)$ & $(6)$ \\
\hline & \multicolumn{2}{|c|}{ Difference in means } & \multicolumn{2}{|c|}{ R\&D contractors } & \multicolumn{2}{|c|}{ Other firms } \\
\hline & $\begin{array}{l}\text { R\&D contractors - } \\
\text { Other firms }\end{array}$ & $\mathrm{t}$ & Mean & Std. dev. & Mean & Std. dev. \\
\hline Sales $(\$ \mathrm{~mm})$ & $4,998.36$ & 45.90 & $5,986.8$ & $21,029.9$ & 988.5 & $4,580.0$ \\
\hline R\&D expenditures $(\$ \mathrm{~mm})$ & 231.64 & 46.57 & 264.9 & 928.4 & 33.3 & 126.5 \\
\hline R\&D intensity & -4.50 & -3.43 & 1.4 & 29.4 & 5.9 & 174.7 \\
\hline Publications per $\$ 1 \mathrm{~mm}$ in R\&D exp. & 0.17 & 3.99 & 0.4 & 5.4 & 0.3 & 4.2 \\
\hline Patents per $\$ 1 \mathrm{~mm}$ in $R \& D$ exp. & -0.66 & -1.65 & 0.6 & 3.5 & 1.2 & 53.6 \\
\hline All grants $(\$ \mathrm{~mm})$ & 0.76 & 6.37 & 0.9 & 10.7 & 0.1 & 8.7 \\
\hline
\end{tabular}

Notes: This table presents mean comparison tests between $\mathrm{R} \& \mathrm{D}$ contractors and other firms. RED intensity is calculated as R\&D expenditures divided by Sales. All grants are summarized for fiscal years 2001-2015. The twosample t-tests use unequal variances.

\section{$5 \quad$ Econometric Specifications}

\subsection{R\&D Expenditures, Publications, Renowned Scientists, and Patents Equa- tions}

Our analyses are conducted at the firm-year level. We estimate the following set of specifications for the relationship between $R \& D$ contracts and corporate $R \& D$ expenditures, publications, renowned scientists, and patents (denoted by $\left.Y_{i, t}\right)$ :

$$
\ln \left(Y_{i, t}\right)=\alpha_{0}+\alpha_{1} \ln \left(R \& D \text { contracts } s_{i, t-3}\right)+\boldsymbol{Z}_{i, t-3}^{\prime} \boldsymbol{\omega}+\boldsymbol{\eta}_{i}+\boldsymbol{\tau}_{t}+\epsilon_{i, t}
$$

$R \& D$ contracts $s_{i, t-3}$ is the dollar value of all $\mathrm{R} \& \mathrm{D}$ contracts awarded to focal firm $i$ (and its subsidiaries) in year $t-3 .{ }^{27}$ The vector $\boldsymbol{Z}$ includes time-varying controls, such as the natural logarithms

\footnotetext{
${ }^{27}$ In Online Appendix $G$ we show that our results are not sensitive to the specific lag structure used.
} 
of sales and R\&D stock. The vectors $\boldsymbol{\eta}$ and $\boldsymbol{\tau}$ are firm fixed effects and year fixed effects, respectively, and $\epsilon$ is an iid error term. All dollar values are adjusted using the GDP Implicit Price Deflator to reflect constant 2012 dollars (U.S. Bureau of Economic Analysis, 2021). When calculating natural logarithms, we add $\$ 1$ to variables measured in millions of dollars (e.g., R\&D expenditures, $R \& D$ contracts, and instrumental variables) and one unit to publications, renowned scientists, and patents variables. Standard errors are clustered at the firm level.

Corporate R\&D activities can be "company-funded" (using the firm's own funds) or "customerfunded" (under contractual arrangements with federal agencies or other customers). We use the fact that company-funded $\mathrm{R} \& \mathrm{D}$ costs are included in $R E \mathcal{E}$ expenditures, while customer-funded $\mathrm{R} \& \mathrm{D}$ costs are expensed under Cost of sales as incurred. Independent company-funded R\&D costs can be recovered as general and administrative overhead costs (i.e., indirect costs) on federal procurement contracts, as long as they are allowable, allocable, and reasonable, in accordance with FAR Part 31. However, the firm still bears the risk of performing the $R \& D$ in hopes of recovering it from future contracts. A crowding-in effect of R\&D contracts implies $\hat{\alpha_{1}}>0$.

\subsection{Identification Strategies}

A major econometric challenge is how to deal with the endogeneity of R\&D contracts. Common shocks can affect both federal procurement and corporate R\&D activity. If the U.S. government targeted firms that experience positive (negative) technology or demand shocks, then the OLS estimate of $\alpha_{1}$ would be upward-biased (downward-biased). We implement two identification strategies to mitigate this concern. First, we construct several instrumental variables that exploit variation in industry-level procurement, agency-level windfall funding resulting from the congressional appropriations process, and product or service code (PSC)-level procurement to predict firm-level R\&D contracts. Second, we exploit the end of the Cold War as a quasi-natural experiment in a panel event study. ${ }^{28}$

\subsubsection{Instrumental Variables}

Our first instrument uses industry-level $R \& D$ contracts to predict firm-level $R \& D$ contracts. We

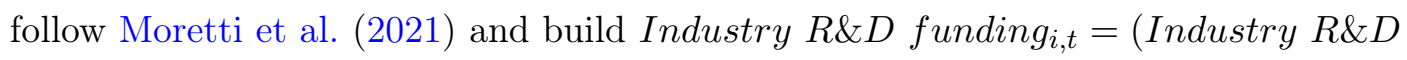

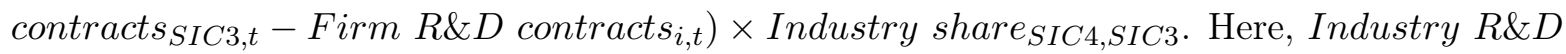
contracts $_{S I C 3, t}$ is the total value of all $\mathrm{R} \& \mathrm{D}$ contracts awarded by federal agencies to firm $i$ 's SIC3 industry in year $t$. Firm $R \& D$ contracts $_{i, t}$ is the value R\&D contracts awarded to firm $i$ in year t. Industry share $\mathrm{SIC}_{4, \mathrm{SIC} 3}$ is calculated by dividing the total value of $\mathrm{R} \& \mathrm{D}$ contracts awarded to firm $i$ 's SIC4 industry during $1980-2015$ by the total value of R\&D contracts awarded to firm $i$ 's higher-level SIC3 industry during 1980-2015. ${ }^{29}$ Additional details about this instrument are

\footnotetext{
${ }^{28}$ In robustness checks, we also use procurement shocks triggered by the end of the Cold War, the Global War on Terrorism, and the Financial Crisis in instrumental variable estimations.

${ }^{29}$ The total value includes all R\&D contracts awarded by all federal agencies to all recipients, not just the R\&D contracts we matched to our sample of firms.
} 
included in Online Appendix D.

Changes in industry-level R\&D contracts may be related to unobserved or mismeasured technology or demand shocks that directly affect firm-level R\&D decisions. To address this possibility, our second instrument leverages variation in the R\&D budget authority of 12 main federal agencies (plus an "Other" category for smaller agencies) sourced from the American Association for the Advancement of Science (AAAS). ${ }^{30}$

Because agency $R \& D$ budgets may reflect technological shocks that are common to the $R \& D$ decisions of firms, our third instrument exploits variation in the difference between the requested budget authority proposed by the executive branch and the actual budget authority appropriated by Congress for each federal agency, building on Dugoua, Gerarden, Myers, and Pless (2022). ${ }^{31}$ Demand for funding (the requested amount) is a function of the common technology shock that can affect both public procurement and corporate R\&D activity. However, the actual budget appropriated by Congress includes a component that is independent of this shock. Hence, we can use an agency's windfall (or shortfall, if negative) in total funding that results from the political negotiation between the executive branch and Congress as a source of exogenous variation in its R\&D budget authority. ${ }^{32}$

The first three instruments are constructed using a similar approach (i.e., subtracting the fo-

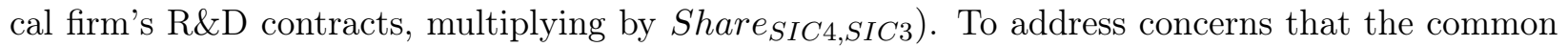
method may introduce a bias in our estimates, we construct our fourth instrument using a different approach. We follow Bartik (1991) and build PSC R\&D funding $i_{i, t}=\sum_{P S C s} R \& D$ contracts $_{P S C, t} \times$ $S_{\text {Share }}, P S C$. Here, $R \& D$ contracts $_{P S C, t}$ is the total value of all R\&D contracts awarded by all federal agencies to purchase the focal PSC in year $t$. This is our shift, and it varies over time but not across firms. Share ${ }_{i, P S C}$ is calculated by dividing the total value of R\&D contracts for the focal PSC awarded to firm $i$ during 1980-2015 by the total value of R\&D contracts awarded to firm $i$ during 1980-2015. This is our exposure share, and it varies across firms but not over time.

\subsubsection{Event Study}

During the Cold War (1948-1989), federal procurement focused on achieving and sustaining technological superiority for the purpose of national security (Weiss, 2014). The large scale and long duration of Cold War threats led to large procurement budgets that were dominated by the DoD (Mowery, 2012). The end of the Cold War removed the perception of an existential threat to the

\footnotetext{
${ }^{30}$ We construct Agency $R \& D$ budget ${ }_{i, t}$ by replacing Industry $R \& D$ contracts $S_{S C 3, t}$ in the first instrument with

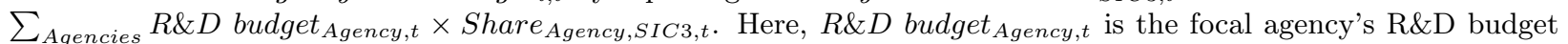
authority in year $t$. Share $A g e n c y, S I C 3, t$ is calculated by dividing the total value of R\&D contracts awarded by the focal agency to firm $i$ 's SIC3 industry in year $t$ by the total value of R\&D contracts awarded by the focal agency in year $t$.

${ }^{31}$ Each annual Budget of the U.S. Government discloses both the amount requested by the agency and the actual amount appropriated by Congress. The difference between actual and requested amounts represents the windfall budget authority. We hand-collect this information for each of the 12 main federal agencies and the "Other" category.

${ }^{32}$ We build Windfall - predicted $R \& D$ budget $_{i, t}$ by replacing $R \& D$ budget $t_{\text {Agency, } t}$ in the second instrument with

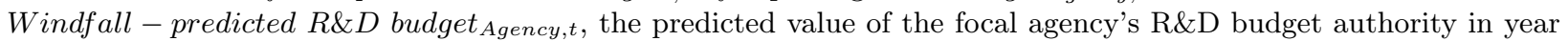
$t$, obtained after regressing the focal agency's R\&D budget authority on its total budget windfall.
} 
United States and drove a massive reallocation of government procurement. ${ }^{33}$ For example, DoD procurement obligations dropped 38\% (from $\$ 225.9$ billion in 1988 to $\$ 140.1$ billion in 1992), while HHS obligations almost tripled (from $\$ 830$ million in 1988 to $\$ 2.3$ billion in 1992).

Overall, public demand declined between 1988 and 1992. On average, industries experienced a $\$ 84$ million reduction in total procurement contracts. Yet, not all industries were equally affected (see Appendix Figure D2 and Appendix Table D8). Among the "winners" receiving increased procurement funding were IT industries (e.g., computer systems design) and health industries (e.g., medicinal chemicals and botanical products). Among the "losers" were the national security industries (e.g., guided missiles and space vehicles). Because the reallocation between industries was caused by geopolitical circumstances, rather than technology shocks, we exploit the end of the Cold War as a quasi-natural experiment in a panel event study. ${ }^{34}$

To isolate the effect of increasing public demand for $R \& D$ when there is no corresponding increase in total demand, our event study focuses on firms in SIC3 industries that received a large increase in R\&D contracts, yet experienced only a moderate change in total demand. A "large" increase in $R \& D$ contracts is a year-over-year change in the value of $R \& D$ contracts awarded to the SIC3 industry that was in the top $20 \%$ of the distribution of changes between 1991 and 1994. A "moderate" change in total demand is a year-over-year change in sales to the SIC3 industry that was in the middle $60 \%$ of the distribution of changes in sales between 1991 and 1994. ${ }^{35}$

The sample for the event study includes 1,941 firms in 26 industries that meet these criteria. ${ }^{36}$ Treatment is the positive $R \& D$ contract shock, and it is staggered (i.e., firms in different industries are shocked at different times in the 1991-1994 time frame). The 151 firms (from 25 industries)

\footnotetext{
${ }^{33}$ The end of the Cold War may have been precipitated by strategic DoD investments (e.g., the Strategic Defense Initiative, or "Star Wars program," introduced by President Reagan in 1983 to neutralize the Soviet nuclear arsenal). To test for this possibility, we exclude R\&D contracts from the DoD and examine the effect of R\&D contracts from civilian agencies, whose procurement funding should not have accelerated the collapse of the Soviet Union. We also test the effect of R\&D contracts on publications using two alternative shocks. The Global War on Terrorism and the Financial Crisis both triggered massive redeployment of federal procurement funds. Yet, these shocks are unlikely to suffer from the same endogeneity problem as the Cold War shock.

${ }^{34}$ We estimate the following specification:

$$
\ln (Y)_{i t}=\sum_{j=2}^{5} \gamma_{j}(\text { Lead } j)_{i t}+\sum_{k=0}^{5} \delta_{k}(\text { Lag } k)_{i t}+\boldsymbol{Z}_{i, t}^{\prime} \boldsymbol{\omega}+\boldsymbol{\eta}_{\boldsymbol{i}}+\boldsymbol{\tau}_{\boldsymbol{t}}+\epsilon_{i, t}
$$

$Y_{i t}$ is R\&D expenditures, Renowned scientists, Publications, and Patents, respectively, for firm $i$ in year $t$. Leads and lags are indicator variables defined as: $(\text { Lead } j)_{i t}=\mathbb{1}\left[t=\right.$ Event $\left._{\text {shock }}-j\right]$ and $(\text { Lag } k)_{i t}=\mathbb{1}\left[t=\right.$ Event $\left._{\text {shock }}+k\right]$. Event $_{\text {shock }} \in\{1991, \ldots, 1994\}$ is the year of the shock. The vector $\boldsymbol{Z}$ includes controls for the natural logarithm of Private demand (calculated as Sales - All contracts) and the percentage change in Private demand. The vectors $\boldsymbol{\eta}$ and $\boldsymbol{\tau}$ are firm fixed effects (to absorb firm-specific, time-invariant heterogeneity) and year fixed effects (to absorb time trends in our staggered treatment design), respectively, and $\epsilon$ is an iid error term.

${ }^{35}$ The median year-over-year change in R\&D contracts awarded to a SIC3 industry during $1991-1994$ was a $24 \%$ decrease. Top $20 \%$ industries had an increase greater than $57.7 \%$. Over the same period, the median year-over-year change in sales to a SIC3 industry was a $2.4 \%$ increase. Bottom $20 \%$ industries had a decrease in sales of $-6.7 \%$ or more, while top $20 \%$ industries had an increase in sales of $15.1 \%$ or more. We used these thresholds (increase in R\&D contracts $\geq 57.7 \%$, change in sales between $-6.7 \%$ and $15.1 \%$ ) to identify SIC3 industries for the event study.

${ }^{36}$ Appendix Figure G4 shows that private demand does not increase for treated firms relative to control firms after the R\&D contract shock, confirming that we have successfully controlled for changes in private demand when constructing our event study sample.
} 
that received $R \& D$ contracts during the pre-period of 1980-1985 represent the treated group, while the remaining 1,790 firms (from 26 industries) represent the control group. Treated firms remain treated for the complete duration of the sample. Estimations use firms that have data for the entire 9 -year period to control for changes in the composition of industries over time. Consistent with the assumption that firms do not anticipate the positive R\&D contract shock, we find that treated and control firms follow parallel pre-trends (as reported in Figure 3).

\subsection{Trends in Contracting and Project Implementation}

We test how the implicit promise of guaranteed demand carried by R\&D contracts has changed over time using two approaches. First, we estimate trends in the value and composition of procurement contracts using the following specification:

$$
\ln \left(\text { Contracts }_{i, t}\right)=\beta_{0}+\beta_{1} \text { Time trend }_{t}+\boldsymbol{Z}_{i, t-1}^{\prime} \boldsymbol{\omega}+\boldsymbol{\eta}_{i}+\epsilon_{i, t}
$$

The indices $i$ and $t$ denote firms and years, respectively. Time trend $d_{t}$ is the focal year $t$ minus 1980 , presented in decennial units. The other elements of this specification are as previously described. We report results using both the dollar values and the shares of RED contracts and Commercial contracts as the dependent variables. Consistent with the view that $R \& D$ races have become less important for government procurement over time, we expect $\widehat{\beta}_{1}<0$ in the $R \mathscr{E} D$ contracts regressions and $\widehat{\beta_{1}}>0$ in the Commercial contracts regressions.

Second, we estimate changes in the relationship between contract value and firm scientific capabilities over time. ${ }^{37}$ Consistent with the view that scientific capabilities have become less important for getting government contracts over time due to the decoupling of $\mathrm{R} \& \mathrm{D}$ contracts and downstream procurement, we expect the coefficient estimate on the interaction term to be negative.

Moreover, we present trend analyses testing the implications of the decoupling for failed project implementation.

\section{$6 \quad$ Estimation Results}

Our results point to a strong crowding-in effect of $R \& D$ contracts on firm-financed upstream $R \& D$ expenditures, consistent with the mechanism of guaranteed demand. We present the detailed analysis below.

\footnotetext{
${ }^{37}$ We estimate the following specification:

$$
\begin{aligned}
& \ln \left(\text { Contracts }_{i, t}\right)=\gamma_{0}+\gamma_{1} \text { Time trend }_{t}+\gamma_{2} \ln \left(\text { Publications stock } k_{i, t-1}\right) \\
& +\gamma_{3} \text { Time trend } \times \ln \left(\text { Publications stock } k_{i, t-1}\right)+\boldsymbol{Z}_{i, t-1}^{\prime} \boldsymbol{\omega}+\boldsymbol{\eta}_{i}+\epsilon_{i, t}
\end{aligned}
$$

Contracts $_{i, t}$ is the flow of noncompeted downstream procurement contract dollars awarded to firm $i$ (and its subsidiaries) in year $t$. Publications stock $k_{i, t-1}$ is calculated using a perpetual inventory method with a $15 \%$ depreciation rate. The other elements of this specification are as previously described. 


\subsection{R\&D Expenditures Equation}

Table 4 presents within-firm estimations results for R\&D expenditures. OLS estimates from Columns 1-2 show that RED expenditures are positively related to RED contracts (p-value $<0.01$ ), regardless of whether we control for firm size. ${ }^{38}$ Our coefficient estimates are similar to those obtained by Moretti et al. (2021) when estimating the relationship of government R\&D subsidies (including both $R \& D$ contracts and grants) with company-funded R\&D using a panel of French firms.

Table 4: Estimation Results for the R\&D Expenditures Equation

\begin{tabular}{|c|c|c|c|c|c|c|c|}
\hline & \multicolumn{7}{|c|}{$\ln (\mathrm{R} \& \mathrm{D}$ expenditures $)$} \\
\hline & $\begin{array}{l}\text { OLS: } \\
\text { Within } \\
\text { firms }\end{array}$ & $\begin{array}{l}\text { OLS: } \\
\text { Within } \\
\text { firms } \\
\text { (Sales } \\
\text { control) }\end{array}$ & $\begin{array}{c}\text { IV: } \\
\text { Industry } \\
\text { R\&D } \\
\text { funding }\end{array}$ & $\begin{array}{c}\text { IV: } \\
\text { Industry } \\
\text { R\&D } \\
\text { funding } \\
\text { (Sales } \\
\text { control) }\end{array}$ & $\begin{array}{c}\text { IV: } \\
\text { Agency } \\
\text { R\&D } \\
\text { budget }\end{array}$ & $\begin{array}{c}\text { IV: } \\
\text { Windfall- } \\
\text { predicted } \\
\text { R\&D } \\
\text { budget }\end{array}$ & $\begin{array}{c}\text { IV: } \\
\text { PSC } \\
\text { R\&D } \\
\text { funding }\end{array}$ \\
\hline $\ln (\mathrm{R} \& \mathrm{D} \text { contracts })_{t-1}$ & $\begin{array}{c}0.012 \\
(0.002)\end{array}$ & $\begin{array}{c}0.007 \\
(0.002)\end{array}$ & $\begin{array}{c}0.069 \\
(0.025)\end{array}$ & $\begin{array}{c}0.060 \\
(0.023)\end{array}$ & $\begin{array}{c}0.055 \\
(0.021)\end{array}$ & $\begin{array}{c}0.055 \\
(0.021)\end{array}$ & $\begin{array}{c}0.072 \\
(0.044)\end{array}$ \\
\hline $\ln (\text { Sales })_{t-2}$ & & $\begin{array}{c}0.369 \\
(0.016)\end{array}$ & & $\begin{array}{c}0.349 \\
(0.016)\end{array}$ & $\begin{array}{c}0.350 \\
(0.016)\end{array}$ & $\begin{array}{c}0.350 \\
(0.016)\end{array}$ & $\begin{array}{c}0.356 \\
(0.018)\end{array}$ \\
\hline Sample years & $1980-2015$ & $1980-2015$ & $1980-2015$ & $1980-2015$ & $1980-2015$ & $1980-2015$ & $1980-2015$ \\
\hline Firm fixed effects & Yes & Yes & Yes & Yes & Yes & Yes & Yes \\
\hline Year fixed effects & Yes & Yes & Yes & Yes & Yes & Yes & Yes \\
\hline Weak identif. (Kleibergen-Paap) & & & 111.31 & 103.12 & 108.07 & 108.30 & 5.62 \\
\hline Firms & 4,284 & 3,828 & 4,228 & 3,767 & 3,770 & 3,772 & 3,828 \\
\hline Observations & 48,853 & 43,407 & 45,669 & 40,413 & 40,452 & 40,465 & 43,394 \\
\hline Adjusted R-squared & 0.893 & 0.919 & -0.030 & 0.122 & 0.125 & 0.126 & 0.083 \\
\hline
\end{tabular}

Notes: This table presents the estimation results for the relationship between R\&D contracts and firm-financed R\&D expenditures. Columns 3-7 present the second stage of 2SLS, where R\&D contracts are instrumented using Industry $R \mathscr{E} D$ funding, Agency RED budget, Windfall-predicted RED budget, and PSC RED funding, as noted. Standard errors (in parentheses) are clustered at the firm level.

Columns 3-7 present the 2SLS estimates. In the first stage regression for Column 3, we predict $R \mathscr{E} D$ contracts awarded to a focal firm using the Industry RED funding instrument (F statistic $=51$, see Column 1 in Appendix Table D9). In the second stage, we regress RED expenditures against the predicted R\&D contracts. As expected, $\hat{\alpha_{1}}>0$ (p-value $<0.01$ ). A larger 2SLS estimate (OLS is downward-biased) suggests that R\&D contracts target areas affected by negative technology or demand shocks. ${ }^{39}$ Evaluated at the sample means, the estimate from Column 4 implies that a $\$ 10$ million increase in $\mathrm{R} \& \mathrm{D}$ contracts crowds in $\$ 4.7$ million in company-funded $\mathrm{R} \& \mathrm{D}$ expenditures. ${ }^{40}$ We obtain similar estimates when instrumenting for $R \mathscr{E} D$ contracts using Agency

\footnotetext{
${ }^{38}$ We lag Sales one additional year to avoid double counting R\&D contract dollars. In unreported specifications, we obtain similar coefficient estimates on $R \mathscr{E} D$ contracts when we use RED stock as a size control.

${ }^{39}$ Government procurement indeed aims to maintain the existing military-industrial base (Peters, 2021). For example, in 1994, the U.S. Congress appropriated $\$ 2.5$ billion for the Defense Reinvestment and Conversion Initiative, a transition assistance program for industries affected by post-Cold War reductions in defense spending (U.S. Government Accountability Office, 1997).

${ }^{40}$ Average values for $R \& D$ expenditures and $R \& D$ contracts are $\$ 100.1$ million and $\$ 12.7$ million, respectively. The
} 
RED budget, Windfall-predicted REDD budget, and PSC RED funding, respectively (Columns 5-7). When excluding one-by-one contracts from each of the seven largest federal agencies, we find that our results are not driven solely by the DoD or another single agency (see Appendix Table G21).

In summary, we find that $R \& D$ contracts crowd-in additional company-funded R\&D investments. Next, we examine the effect of R\&D contracts separately for upstream and downstream R\&D. Consistent with the guaranteed demand mechanism, which is more likely to be used when implementing knowledge in production is harder, we expect the effect of $R \& D$ contracts to be strong for upstream R\&D (measured using publications and renowned scientists), but not for downstream $\mathrm{R} \& \mathrm{D}$ (measured using patents).

\subsection{Publications Equation}

Table 5 presents the estimation results for publications, our output measure of upstream corporate R\&D. In Column 1, Publications are positively related to RED contracts ( $\mathrm{p}$-value $<0.001$ ). In unreported specifications, we obtain similar coefficient estimates on $R \mathscr{E} D$ contracts when we replace RED stock with Sales or drop the size control altogether.

Columns 2-3 present 2SLS results using Industry RED funding and Windfall-predicted RED budget as instruments, respectively. Evaluated at the sample means, the estimate in Column 2 implies that $\$ 24.4$ million in additional R\&D contracts lead to one additional corporate publication. ${ }^{41}$ Once again, the 2SLS estimate is larger than OLS, suggesting that government R\&D contracts target firms that face negative technology or demand shocks. ${ }^{42}$

The next two columns present subsample analyses using firms that publish at least one paper (Column 4) or employ at least one award-winning renowned scientist (Column 5) during 19802015. These firms are more likely to engage in upstream R\&D. Consistent with the guaranteed demand mechanism, we expect the co-investment incentive to be stronger for these firms. Indeed, the coefficient estimate on $R \& D$ contracts is larger for these firm subsamples. Evaluated at the sample means, the estimate implies that it takes only $\$ 15.4$ million in additional $\mathrm{R} \& \mathrm{D}$ contracts to produce one additional publication among firms that employ award-winning scientists. ${ }^{43}$

Our analyses thus far focused on the number of corporate publications, rather than on their quality. In Columns 6-7 we use a quality-adjusted measure of upstream R\&D, obtained by weighting each publication by the number of citations received from other publications. ${ }^{44}$ Appendix Table G20 uses two other measures of publication quality: publications authored by renowned scientists or cited by renowned scientists. The coefficient estimates suggest that firms are not simply increasing

marginal effect of an additional $\$ 10$ million in $R \& D$ contracts is $10 \times 0.060(100.1+0.000001) /(12.7+0.000001)=4.7$ million in additional company-funded R\&D expenditures.

${ }^{41}$ Average values for publications and $R \& D$ contracts are 13 and $\$ 12$ million, respectively. The marginal effect of an additional $\$ 10$ million in $R \& D$ contracts is $10 \times 0.035(13+1) /(12+0.000001)=0.41$ publications, representing a $3 \%$ increase relative to the mean.

${ }^{42}$ In unreported specifications, we obtain a coefficient estimate of 0.029 when we drop the control for $R \mathscr{E} D$ stock.

${ }^{43}$ Average values for publications and R\&D contracts are 51 and $\$ 54$ million, respectively. The marginal effect of an additional $\$ 1$ million in $R \& D$ contracts is $0.068(51+1) /(54+0.000001)=0.065$ publications.

${ }^{44}$ We use normalized citations, calculated as (Forward citations received from other publications up to the year 2016) / (Average forward citations received by all publications published in the same journal and year). 
Table 5: Estimation Results for the Publications Equation

\begin{tabular}{|c|c|c|c|c|c|c|c|}
\hline & $(1)$ & $(2)$ & $\begin{array}{c}(3) \\
\ln (\text { Publica }\end{array}$ & ations) & $(5)$ & \multicolumn{2}{|c|}{$\begin{array}{c}(6) \\
\ln (\text { Citation-weighted } \\
\text { publications })\end{array}$} \\
\hline & $\begin{array}{l}\text { OLS: } \\
\text { Within } \\
\text { firms }\end{array}$ & $\begin{array}{l}\text { IV: } \\
\text { Industry } \\
\text { R\&D } \\
\text { funding }\end{array}$ & $\begin{array}{c}\text { IV: } \\
\text { Windfall- } \\
\text { predicted } \\
\text { R\&D } \\
\text { budget }\end{array}$ & $\begin{array}{c}\text { IV: } \\
\text { Windfall- } \\
\text { predicted } \\
\text { R\&D } \\
\text { budget } \\
\text { (Publishing } \\
\text { firms) }\end{array}$ & $\begin{array}{c}\text { IV: } \\
\text { Windfall- } \\
\text { predicted } \\
\text { R\&D } \\
\text { budget } \\
\text { (Award-winning } \\
\text { scientist } \\
\text { employers) }\end{array}$ & $\begin{array}{c}\text { IV: } \\
\text { Industry } \\
\text { R\&D } \\
\text { funding }\end{array}$ & $\begin{array}{c}\text { IV: } \\
\text { Windfall- } \\
\text { predicted } \\
\text { R\&D } \\
\text { budget }\end{array}$ \\
\hline $\ln (\mathrm{R} \& \mathrm{D} \text { contracts })_{t-3}$ & $\begin{array}{c}0.011 \\
(0.002)\end{array}$ & $\begin{array}{c}0.035 \\
(0.018)\end{array}$ & $\begin{array}{c}0.033 \\
(0.017)\end{array}$ & $\begin{array}{c}0.037 \\
(0.018)\end{array}$ & $\begin{array}{c}0.068 \\
(0.023)\end{array}$ & $\begin{array}{c}0.036 \\
(0.021)\end{array}$ & $\begin{array}{c}0.034 \\
(0.020)\end{array}$ \\
\hline $\ln (\mathrm{R} \& \mathrm{D} \text { stock })_{t-3}$ & $\begin{array}{c}0.131 \\
(0.011)\end{array}$ & $\begin{array}{c}0.114 \\
(0.010)\end{array}$ & $\begin{array}{c}0.115 \\
(0.010)\end{array}$ & $\begin{array}{c}0.147 \\
(0.013)\end{array}$ & $\begin{array}{c}0.256 \\
(0.033)\end{array}$ & $\begin{array}{c}0.105 \\
(0.011)\end{array}$ & $\begin{array}{c}0.105 \\
(0.011)\end{array}$ \\
\hline Sample years & $1980-2015$ & $1980-2015$ & $1980-2015$ & $1980-2015$ & $1980-2015$ & $1980-2015$ & $1980-2015$ \\
\hline Firm fixed effects & Yes & Yes & Yes & Yes & Yes & Yes & Yes \\
\hline Year fixed effects & Yes & Yes & Yes & Yes & Yes & Yes & Yes \\
\hline Weak identif. (Kleibergen-Paap) & & 101.13 & 105.37 & 94.74 & 41.77 & 101.13 & 105.37 \\
\hline Firms & 3,632 & 3,580 & 3,585 & 2,647 & 598 & 3,580 & 3,585 \\
\hline Observations & 43,914 & 41,047 & 41,100 & 32,349 & 9,444 & 41,047 & 41,100 \\
\hline Adjusted R-squared & 0.873 & 0.016 & 0.017 & 0.022 & 0.014 & 0.006 & 0.007 \\
\hline
\end{tabular}

Notes: This table presents the estimation results for the relationship between R\&D contracts and publications. Columns 2-7 present the second stage of 2SLS, where R\&D contracts are instrumented using Industry RED funding, Agency RED budget, and Windfall-predicted RED budget, as noted. Column 4 uses a subsample of firms that publish at least one paper during 1980-2015. Column 5 uses a subsample of firms that employ at least one award-winning renowned scientist during 1980-2015. In Columns 6-7, the publication flow is weighted by citations received from other publications, normalized by average journal-year citations. Standard errors (in parentheses) are clustered at the firm level.

the number of publications while lowering their quality in response to winning $R \& D$ contracts.

We report additional robustness checks in Online Appendix Sections F and G. The effect of R\&D contracts on publications is present across all industries (Table F16), and is robust to excluding contracts from each of the seven largest agencies (Table G22) or using other funding shocks (Table G24), alternative specifications (Table G25), and different time lags (Table G27). Importantly, we find no evidence to suggest that R\&D contracts crowd out unrelated research areas (Table G30).

In summary, we document a crowding-in effect of $R \& D$ contracts on upstream $R \& D$. Since upstream R\&D should be harder to implement in downstream procurement, this finding is consistent with the guaranteed demand mechanism.

\subsection{Renowned Scientists Equation}

Table 6 presents the estimation results for renowned scientists, our second measure of upstream R\&D. Columns 2-4 present 2SLS estimates using Industry RED funding, Agency RED budget, and Windfall-predicted RED budget as instruments for RED contracts, respectively. Evaluated at the sample means, the estimate in Column 2 implies that $\$ 37$ million in additional R\&D contracts lead 
to hiring one additional renowned scientist. ${ }^{45}$

Column 5 uses a subsample of firms that employ at least one renowned scientist during our sample period, 1980-2015. As expected, the coefficient estimate is significant and larger in magnitude compared to the full sample. Moreover, our results are robust to replacing our dependent variable with growth in employment of renowned scientists (Columns 6-7).

Table 6: Estimation Results for the Renowned Scientists Equation

\begin{tabular}{|c|c|c|c|c|c|c|c|}
\hline & \multicolumn{5}{|c|}{$\begin{array}{l}\ln \text { (Renowned } \\
\text { scientists) }\end{array}$} & \multicolumn{2}{|c|}{$\begin{array}{l}(6) \quad(7) \\
\ln (\text { Change in } \\
\text { renowned scientists })\end{array}$} \\
\hline & $\begin{array}{l}\text { OLS: } \\
\text { Within } \\
\text { firms }\end{array}$ & $\begin{array}{l}\text { IV: } \\
\text { Industry } \\
\text { R\&D } \\
\text { funding }\end{array}$ & $\begin{array}{l}\text { IV: } \\
\text { Agency } \\
\text { R\&D } \\
\text { budget }\end{array}$ & $\begin{array}{c}\text { IV: } \\
\text { Windfall- } \\
\text { predicted } \\
\text { R\&D } \\
\text { budget }\end{array}$ & $\begin{array}{c}\text { IV: } \\
\text { Windfall- } \\
\text { predicted } \\
\text { R\&D } \\
\text { budget } \\
\text { (Scientist } \\
\text { employers) }\end{array}$ & $\begin{array}{c}\text { IV: } \\
\text { Industry } \\
\text { R\&D } \\
\text { funding }\end{array}$ & $\begin{array}{c}\text { IV: } \\
\text { Windfall- } \\
\text { predicted } \\
\text { R\&D } \\
\text { budget }\end{array}$ \\
\hline $\ln (\mathrm{R} \& \mathrm{D} \text { contracts })_{t-1}$ & $\begin{array}{c}0.006 \\
(0.001)\end{array}$ & $\begin{array}{c}0.023 \\
(0.009)\end{array}$ & $\begin{array}{c}0.022 \\
(0.008)\end{array}$ & $\begin{array}{c}0.023 \\
(0.008)\end{array}$ & $\begin{array}{c}0.027 \\
(0.011)\end{array}$ & $\begin{array}{c}0.0034 \\
(0.0019)\end{array}$ & $\begin{array}{c}0.0035 \\
(0.0018)\end{array}$ \\
\hline $\ln (\mathrm{R} \& \mathrm{D} \text { stock })_{t-1}$ & $\begin{array}{c}0.045 \\
(0.006)\end{array}$ & $\begin{array}{c}0.040 \\
(0.006)\end{array}$ & $\begin{array}{c}0.040 \\
(0.006)\end{array}$ & $\begin{array}{c}0.040 \\
(0.006)\end{array}$ & $\begin{array}{c}0.077 \\
(0.011)\end{array}$ & $\begin{array}{l}-0.005 \\
(0.001)\end{array}$ & $\begin{array}{l}-0.005 \\
(0.001)\end{array}$ \\
\hline Sample years & $1980-2015$ & $1980-2015$ & $1980-2015$ & $1980-2015$ & $1980-2015$ & $1980-2015$ & $1980-2015$ \\
\hline Firm fixed effects & Yes & Yes & Yes & Yes & Yes & Yes & Yes \\
\hline Year fixed effects & Yes & Yes & Yes & Yes & Yes & Yes & Yes \\
\hline Weak identif. (Kleibergen-Paap) & & 111.92 & 116.76 & 116.80 & 80.91 & 111.92 & 116.80 \\
\hline Firms & 4,370 & 4,315 & 4,318 & 4,320 & 1,675 & 4,315 & 4,320 \\
\hline Observations & 52,898 & 49,638 & 49,681 & 49,696 & 22,864 & 49,638 & 49,696 \\
\hline Adjusted R-squared & 0.922 & -0.006 & -0.004 & -0.005 & 0.003 & -0.006 & -0.006 \\
\hline
\end{tabular}

Notes: This table presents the estimation results for the relationship between R\&D contracts and renowned scientists. Columns 2-7 present the second stage of $2 \mathrm{SLS}$, where R\&D contracts are instrumented using Industry RED funding, Agency RED budget, and Windfall-predicted RED budget, as noted. Column 5 uses a subsample of firms that employ at least one renowned scientist during 1980-2015. Standard errors (in parentheses) are clustered at the firm level.

In summary, the renowned scientists results complement those for publications, easing concerns that publications are a noisy measure of upstream R\&D.

\subsection{Patents Equation}

Table 7 presents the estimation results for patents, our measure of the output from downstream corporate R\&D. In Column 1, Patents appear to have a positive relationship with RED contracts ( $\mathrm{p}$-value $<0.001)$. However, the coefficient estimate is no longer statistically different from zero once we instrument for R\&D contracts using Industry R\&D funding and Windfall-predicted RED budget, respectively (Columns 2-3).

\footnotetext{
${ }^{45}$ Average values for renowned scientists and $\mathrm{R} \& \mathrm{D}$ contracts are .27 and $\$ 11$ million, respectively. The marginal effect of an additional $\$ 10$ million in $R \& D$ contracts is $10 \times 0.023(.27+1) /(11+0.000001)=0.027$ renowned scientists, representing a $10 \%$ increase relative to the mean. In unreported specifications, we obtain a coefficient estimate of 0.021 when we drop the control for $R \mathscr{E} D$ stock.
} 
Finding no effect for patents is consistent with guaranteed demand being less likely to be used in downstream $\mathrm{R} \& \mathrm{D}$. Because implementation concerns for downstream $\mathrm{R} \& \mathrm{D}$ are relatively low, the government should be less likely to guarantee downstream procurement contracts. As a result, firms should not co-invest in downstream knowledge. Instead, firms may fully substitute their own investments in downstream $R \& D$ with funding from $R \& D$ contracts. Our results are consistent with this logic. 46

Table 7: Estimation Results for the Patents Equation

\begin{tabular}{|c|c|c|c|c|c|c|c|}
\hline & \multirow[t]{2}{*}{ (1) } & \multirow{2}{*}{\multicolumn{2}{|c|}{$\begin{array}{c}(2) \\
\ln \text { (Patents) }\end{array}$}} & \multirow{2}{*}{\multicolumn{2}{|c|}{$\begin{array}{c}(4) \quad(5) \\
\ln (\text { Citation-weighted } \\
\text { patents })\end{array}$}} & \multirow{2}{*}{\multicolumn{2}{|c|}{$\begin{array}{c}(6) \quad(7) \\
\ln (\text { Breakthrough } \\
\text { patents })\end{array}$}} \\
\hline & & & & & & & \\
\hline & $\begin{array}{l}\text { OLS: } \\
\text { Within } \\
\text { firms }\end{array}$ & $\begin{array}{c}\text { IV: } \\
\text { Industry } \\
\text { R\&D } \\
\text { funding }\end{array}$ & $\begin{array}{c}\text { IV: } \\
\text { Windfall- } \\
\text { predicted } \\
\text { R\&D } \\
\text { budget }\end{array}$ & $\begin{array}{c}\text { IV: } \\
\text { Industry } \\
\text { R\&D } \\
\text { funding }\end{array}$ & $\begin{array}{c}\text { IV: } \\
\text { Windfall- } \\
\text { predicted } \\
\text { R\&D } \\
\text { budget }\end{array}$ & $\begin{array}{c}\text { IV: } \\
\text { Industry } \\
\text { R\&D } \\
\text { funding }\end{array}$ & $\begin{array}{c}\text { IV: } \\
\text { Windfall- } \\
\text { predicted } \\
\text { R\&D } \\
\text { budget }\end{array}$ \\
\hline $\ln (\mathrm{R} \& \mathrm{D} \text { contracts })_{t-3}$ & $\begin{array}{c}0.010 \\
(0.002)\end{array}$ & $\begin{array}{c}-0.040 \\
(0.023)\end{array}$ & $\begin{array}{c}-0.037 \\
(0.022)\end{array}$ & $\begin{array}{l}-0.049 \\
(0.025)\end{array}$ & $\begin{array}{l}-0.045 \\
(0.024)\end{array}$ & $\begin{array}{c}-0.002 \\
(0.009)\end{array}$ & $\begin{array}{l}-0.002 \\
(0.008)\end{array}$ \\
\hline $\ln (\mathrm{R} \& \mathrm{D} \text { stock })_{t-3}$ & $\begin{array}{c}0.252 \\
(0.015)\end{array}$ & $\begin{array}{c}0.241 \\
(0.015)\end{array}$ & $\begin{array}{c}0.242 \\
(0.015)\end{array}$ & $\begin{array}{c}0.224 \\
(0.015)\end{array}$ & $\begin{array}{c}0.225 \\
(0.015)\end{array}$ & $\begin{array}{c}0.034 \\
(0.005)\end{array}$ & $\begin{array}{c}0.035 \\
(0.005)\end{array}$ \\
\hline Sample years & 1980-2015 & $1980-2015$ & $1980-2015$ & $1980-2015$ & $1980-2015$ & $1980-2015$ & $1980-2015$ \\
\hline Firm fixed effects & Yes & Yes & Yes & Yes & Yes & Yes & Yes \\
\hline Year fixed effects & Yes & Yes & Yes & Yes & Yes & Yes & Yes \\
\hline Weak identif. (Kleibergen-Paap) & & 101.13 & 105.37 & 101.13 & 105.37 & 101.13 & 105.37 \\
\hline Firms & 3,632 & 3,580 & 3,585 & 3,580 & 3,585 & 3,580 & 3,585 \\
\hline Observations & 43,914 & 41,047 & 41,100 & 41,047 & 41,100 & 41,047 & 41,100 \\
\hline Adjusted R-squared & 0.847 & 0.046 & 0.048 & 0.019 & 0.022 & 0.007 & 0.007 \\
\hline
\end{tabular}

Notes: This table presents the estimation results for the relationship between R\&D contracts and patents. Columns 2-7 present the second stage of 2SLS, where R\&D contracts are instrumented using Industry RED funding or Windfallpredicted $R \& D$ budget, as noted. In Columns 4-5, the patent flow is weighted by citations received from other patents, normalized by International Patent Classification (IPC) class-year. In Columns 6-7, breakthrough patents are in the top $1 \%$ of forward citations in a five-year window relative to other patents from the same application cohort. Standard errors (in parentheses) are clustered at the firm level.

In the last four columns, we use quality-adjusted measures of patents. In Columns 4-5 we weight the flow of corporate patents by the number of citations received from other patents. ${ }^{47}$ Conversely, in Columns 6-7 we use the flow of breakthrough patents (i.e., patents in the top $1 \%$ of forward

\footnotetext{
${ }^{46}$ Prior studies that find a positive effect on patents either estimate the effect of grants (e.g., Azoulay et al., 2019; Howell, 2017) or focus on patenting in small firms (e.g., Howell et al., 2021). Conversely, we estimate the effect of R\&D contracts (which are fundamentally different from grants) on patenting in large firms (which are less likely to be resource constrained or to depend on continued funding from the federal government). There are several other reasons why there should be no or little effect of $R \& D$ contracts on patents. First, guaranteed demand may reduce the need to exclude rivals via costly patenting. Second, some R\&D contracts may prohibit patenting to protect sensitive technologies, though Howell et al. (2021) suggest that this is not a significant concern for most contractors. Third, private market incentives may already be stronger for technology development, rendering guaranteed demand less effective in driving downstream R\&D.

${ }^{47}$ We use normalized citations, calculated as (Forward citations it received from other patents up to the year 2016) / (Average forward citations received by all granted patents in the same 4-digit International Patent Classification and year).
} 
citations in a five-year window relative to other patents from the same application cohort). The coefficient estimates imply that firms are not simply becoming more selective in their patenting in response to winning $R \& D$ contracts.

In summary, we do not find evidence that R\&D contracts crowd-in downstream R\&D (as measured by corporate patents). In light of our publications and renowned scientists results, this highlights the importance of distinguishing between upstream scientific research ("R") and downstream technology development ("D") in corporate R\&D.

\subsection{Event Study Analysis: The End of the Cold War}

Figure 3 presents results from the Cold War event study. The point estimates capture the difference between treated and control firms compared to the prevailing difference in the omitted base period (i.e., year -1, indicated with a vertical line). The coefficient estimates on pre-treatment years (i.e., years $-4,-3,-2$, and -1 ) show that we have parallel pre-trends in all specifications, suggesting that firms do not anticipate the procurement shock. The results indicate that, to the extent there is a crowding-in effect of R\&D contracts on corporate innovation, it occurs in upstream R\&D (Panels $\mathrm{B}$ and $\mathrm{C}$, consistent with the results in Tables 5 and 6) and not in downstream R\&D (panel D, consistent with the results in Table 7). These results are robust to dropping the controls for the level and percentage change in private demand (see Appendix Figure G4).

\subsection{Additional Evidence on Guaranteed Demand}

Because the promise of guaranteed demand is unobserved ex ante (in the R\&D contract data) or ex post (by systematically linking noncompetitive downstream procurement contracts to the specific R\&D contracts that led to them), we identify the guaranteed demand mechanism indirectly. Here we present additional evidence consistent with our mechanism by examining how the effect of $\mathrm{R} \& \mathrm{D}$ contracts on upstream and downstream corporate $\mathrm{R} \& \mathrm{D}$ varies with industry-level guaranteed demand and private market incentives to invest in upstream $\mathrm{R} \& \mathrm{D}$.

\subsubsection{Industry Guaranteed Demand}

Table 8 examines how the effect of R\&D contracts varies with the industry prevalence of noncompetitive downstream contracts. High guaranteed demand industries have top quartile shares of noncompetitive downstream procurement contracts in all downstream procurement contracts (relative to all industries in the same year). The remaining industries have Low guaranteed demand. Columns 1-4 present 2SLS results using the Industry RESD funding instrument. The effect of R\&D contracts on publications is strong for firms operating in high guaranteed demand industries (Column 1 , p-value $=0.056){ }^{48}$ Conversely, there is still no effect on patents (Columns 3-4).

\footnotetext{
${ }^{48}$ In unreported specifications, we obtain similar results when we control for quality by weighing each publication by the number of citations received from other publications.
} 
A. R\&D Expenditures

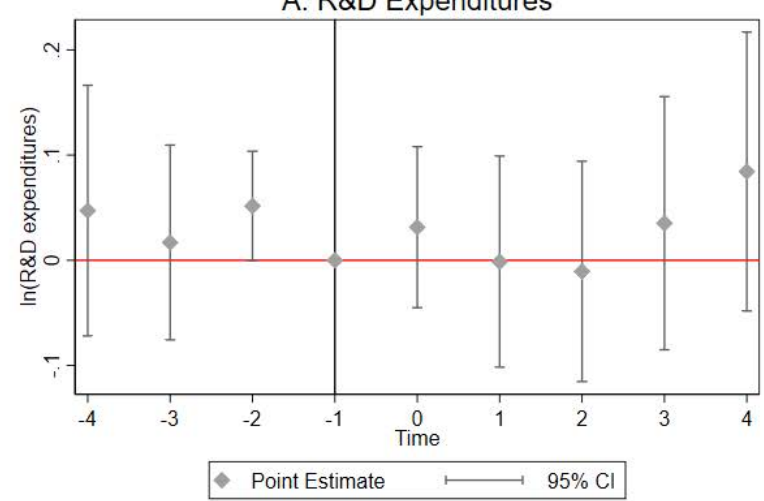

C. Renowned Scientists

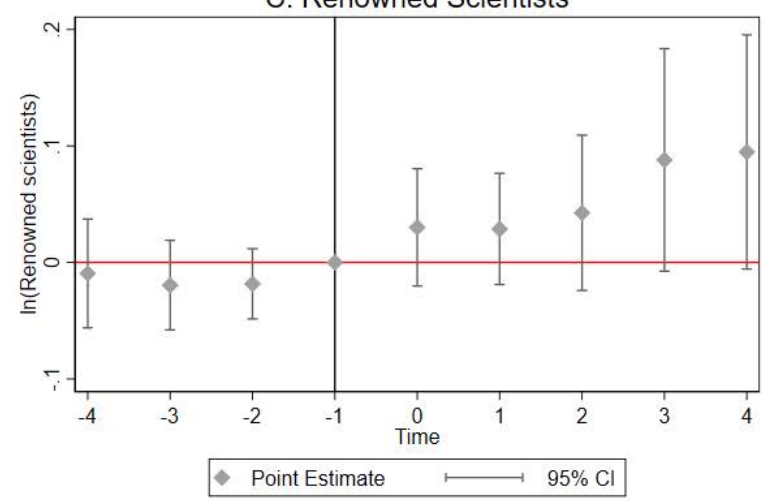

B. Publications

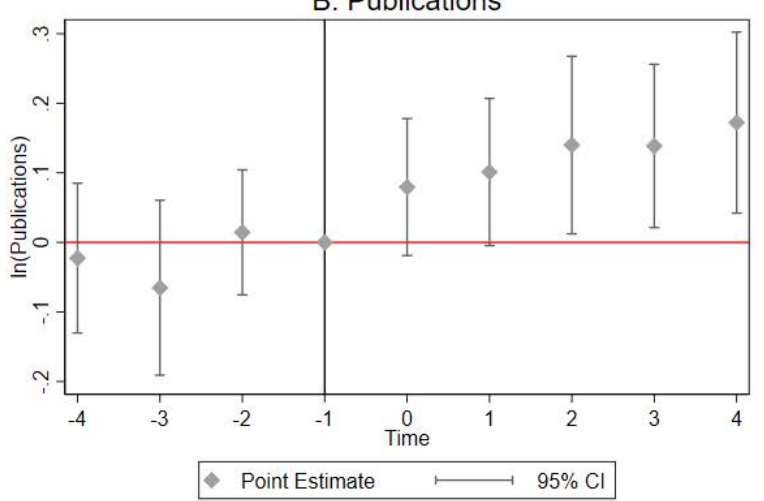

D. Patents

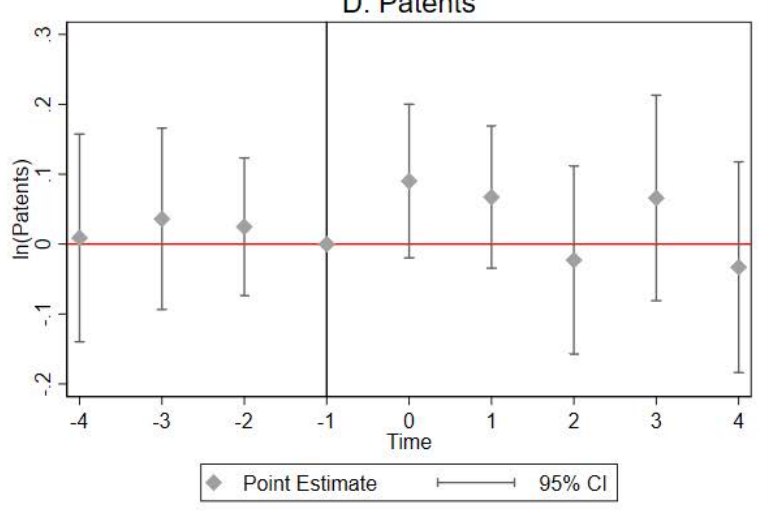

Figure 3: Event Study Around the End of the Cold War

This figure presents an event study around the end of the Cold War. All specifications use firm fixed effects and year fixed effects, as well as controls for the level and percentage change in private demand (i.e., sales net of all procurement contracts). All specifications are estimated using firms that have data for the entire 9-year period to control for changes in the composition of industries over time. Standard errors are clustered at the firm level.

Appendix Table G31 examines how the effect of R\&D contracts varies with an awarding agency's ability to guarantee demand. The share of noncompetitive downstream procurement contracts in all contracts awarded by the Air Force, Navy, and Army during 1980-2015 was 52\%, 58\%, and $50 \%$, respectively. Conversely, DARPA's was just $0.2 \%$. Consistent with the guaranteed demand mechanism, R\&D contracts from the Air Force, Navy, and Army have a strong effect on publications, while R\&D contracts from DARPA have none.

Columns 5-7 of Table 8 show that winning an R\&D contract is positively associated with the value of noncompetitive downstream procurement contracts received in the future ( $\mathrm{p}$-values $<0.001$ ), while winning a grant is not. This result is important because the guaranteed demand mechanism should be distinct from a financing mechanism. Indeed, Column 7 indicates that R\&D contracts are not just financial resources that lower the cost of performing corporate R\&D, they carry the implicit promise of future noncompetitive downstream procurement. 
Table 8: Variation by Industry Guaranteed Demand

\begin{tabular}{|c|c|c|c|c|c|c|c|}
\hline & \multirow{2}{*}{\multicolumn{2}{|c|}{$\begin{array}{l}(1) \\
\ln (\text { Publications })\end{array}$}} & \multirow{2}{*}{\multicolumn{2}{|c|}{$\begin{array}{l}\text { (3) } \\
\ln \text { (Patents) }\end{array}$}} & \multirow{2}{*}{\multicolumn{3}{|c|}{$\begin{array}{l}(5) \\
\ln (\text { Noncompeted downstream } \\
\text { procurement contracts) }\end{array}$}} \\
\hline & & & & & & & \\
\hline & $\begin{array}{c}\text { High } \\
\text { guaranteed } \\
\text { demand } \\
\text { (IV: Ind. } \\
\text { R\&D fund.) }\end{array}$ & $\begin{array}{c}\text { Low } \\
\text { guaranteed } \\
\text { demand } \\
\text { (IV: Ind. } \\
\text { R\&D fund.) }\end{array}$ & $\begin{array}{c}\text { High } \\
\text { guaranteed } \\
\text { demand } \\
\text { (IV: Ind. } \\
\text { R\&D fund.) }\end{array}$ & $\begin{array}{c}\text { Low } \\
\text { guaranteed } \\
\text { demand } \\
\text { (IV: Ind. } \\
\text { R\&D fund.) }\end{array}$ & $\begin{array}{l}\text { Contract } \\
\text { indicator } \\
\text { (OLS: } \\
\text { Within } \\
\text { firms) }\end{array}$ & $\begin{array}{l}\text { Grant } \\
\text { indicator } \\
\text { (OLS: } \\
\text { Within } \\
\text { firms) }\end{array}$ & $\begin{array}{l}\text { Both } \\
\text { indicators } \\
\text { (OLS: } \\
\text { Within } \\
\text { firms) }\end{array}$ \\
\hline $\ln (\mathrm{R} \& \mathrm{D} \text { contracts })_{t-3}$ & $\begin{array}{c}0.103 \\
(0.054)\end{array}$ & $\begin{array}{c}0.030 \\
(0.020)\end{array}$ & $\begin{array}{c}0.041 \\
(0.076)\end{array}$ & $\begin{array}{l}-0.045 \\
(0.024)\end{array}$ & & & \\
\hline $\ln (\mathrm{R} \& \mathrm{D} \text { stock })_{t-3}$ & $\begin{array}{c}0.093 \\
(0.023)\end{array}$ & $\begin{array}{c}0.117 \\
(0.011)\end{array}$ & $\begin{array}{c}0.247 \\
(0.037)\end{array}$ & $\begin{array}{c}0.234 \\
(0.015)\end{array}$ & & & \\
\hline$[\text { Has } \mathrm{R} \& \mathrm{D} \text { contracts }=1]_{t-1}$ & & & & & $\begin{array}{c}1.610 \\
(0.158)\end{array}$ & & $\begin{array}{c}1.607 \\
(0.158)\end{array}$ \\
\hline$[\text { Has grants }=1]_{t-1}$ & & & & & & $\begin{array}{c}0.208 \\
(0.179)\end{array}$ & $\begin{array}{c}0.137 \\
(0.174)\end{array}$ \\
\hline $\ln (\mathrm{R} \& \mathrm{D} \text { stock })_{t-1}$ & & & & & $\begin{array}{c}0.330 \\
(0.051)\end{array}$ & $\begin{array}{c}0.347 \\
(0.052)\end{array}$ & $\begin{array}{c}0.330 \\
(0.051)\end{array}$ \\
\hline Sample years & $1980-2015$ & $1980-2015$ & $1980-2015$ & $1980-2015$ & $1980-2015$ & $1980-2015$ & $1980-2015$ \\
\hline Firm fixed effects & Yes & Yes & Yes & Yes & Yes & Yes & Yes \\
\hline Year fixed effects & Yes & Yes & Yes & Yes & Yes & Yes & Yes \\
\hline Weak identif. (Kleibergen-Paap) & 14.53 & 89.79 & 14.53 & 89.79 & & & \\
\hline Firms & 1,218 & 3,353 & 1,218 & 3,353 & 4,366 & 4,366 & 4,366 \\
\hline Observations & 6,478 & 33,937 & 6,478 & 33,937 & 52,885 & 52,885 & 52,885 \\
\hline Adjusted R-squared & -0.141 & 0.021 & 0.056 & 0.039 & 0.711 & 0.709 & 0.711 \\
\hline
\end{tabular}

Notes: This table presents results from estimating how the effect of R\&D contracts on publications and patents varies by industry guaranteed demand. Standard errors (in parentheses) are clustered at the firm level.

\subsubsection{Private Market Incentives to Invest in Upstream R\&D}

Consistent with the guaranteed demand mechanism, we expect $R \& D$ contracts to have a strong effect on publications that are further away from downstream implementation. Empirically, we expect a strong effect for publications that (i) are not cited by the firm's own patents (the science is missing downstream applications), (ii) are cited by rival firms' patents (the science spills over to product-market competitors), and (iii) are not protected by the firm's own patents (the science is harder to appropriate). ${ }^{49}$

Table 9 presents 2SLS results using Industry RED funding as an instrument for RESD contracts that confirm these predictions. When comparing the effect of R\&D contracts on publications with and without downstream applications inside the inventing firm, we find that the effect is strong when the science does not have internal use (p-value $<0.05$ in Column 2). ${ }^{50}$ When the science has low vs. high spillover to product-market rivals, the effect is strong for publications that are

\footnotetext{
${ }^{49}$ Private market incentives to invest in upstream R\&D depend on the firm's anticipated return on investment. Because we do not observe ex-ante measures of private market incentives at the firm-year level, we rely instead on ex-post measures that should be positively correlated with the unobserved ex-ante measures.

${ }^{50}$ The construction of the internal use, rival use, and scope of patent protection measures is detailed in Online Appendix C.
} 
highly cited by rival firm patents (p-value $<0.01$ in Column 4). ${ }^{51}$ When the science has low vs. high protection from the firm's own patents, the effect is strong when publications are unlikely to be protected by a patent ( $\mathrm{p}$-value $=0.06$ in Column 6 ). In unreported specifications, we obtain broadly similar results when using the Windfall-predicted R\&D budget instrument.

Table 9: VAriation by Private Market Incentives to Invest in Upstream R\&D

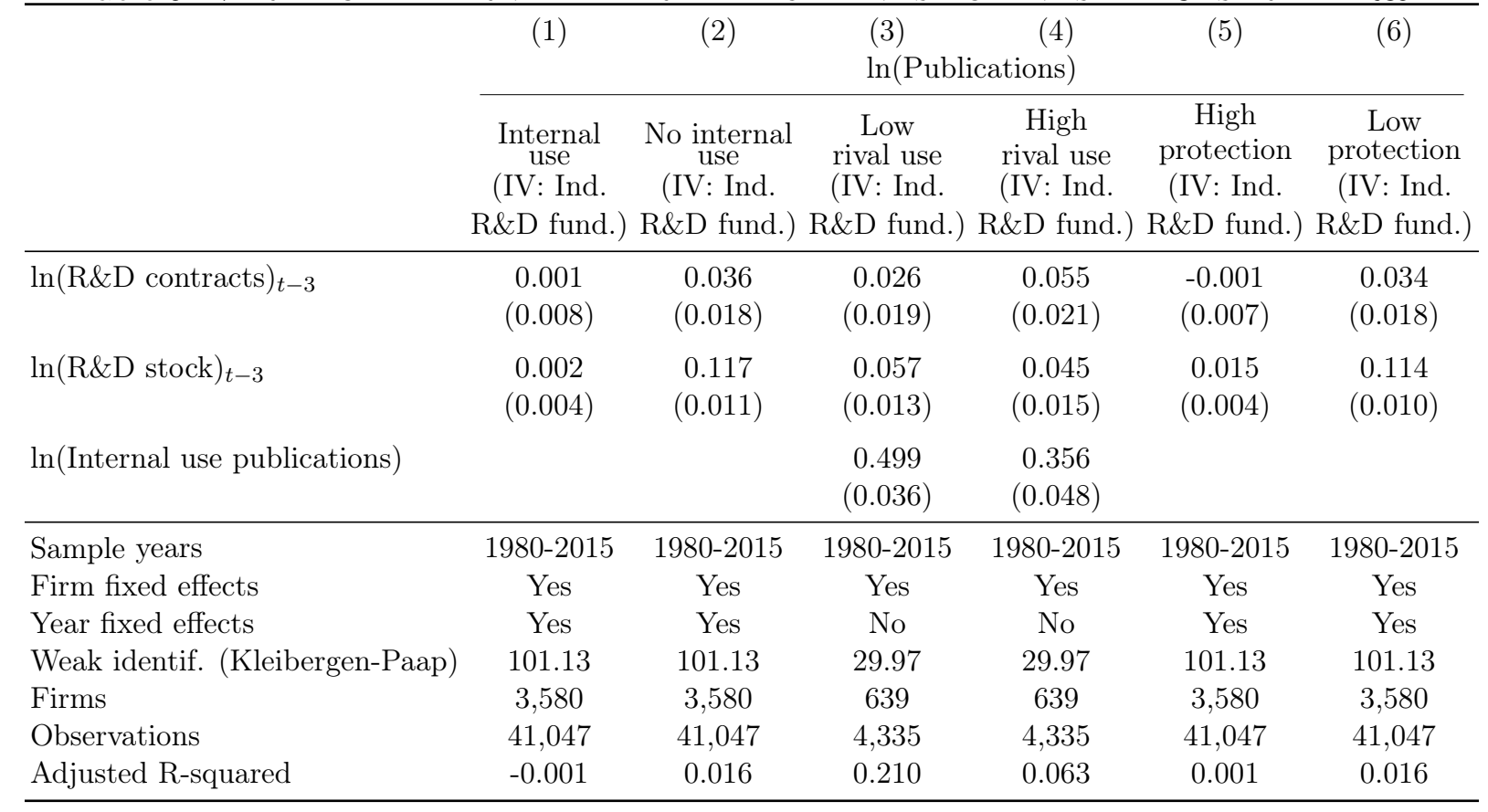

Notes: This table presents second stage results from estimating how the effect of R\&D contracts on publications varies by private market incentives to invest in science. In all specifications, Industry RED funding is used as an instrument for $R E B D$ contracts. Standard errors (in parentheses) are clustered at the firm level.

In summary, R\&D contracts crowd in corporate science that is further away from downstream implementation, consistent with the mechanism of guaranteed demand.

\subsection{Changes Over Time}

Policy reforms implemented in the 1980s and 1990s, such as the Federal Acquisition Streamlining Act of 1994 (see Online Appendix A), have changed the nature and composition of federal procurement. We document these changes and explore possible implications, focusing on the decoupling of R\&D races from downstream procurement and the weakening implicit promise of guaranteed demand.

Figure 4 highlights three key trends: (i) a decreased importance of R\&D races in total procurement; (ii) a rise in competitive procurement; and (iii) a larger allocation of contracts to firms that do not participate in scientific research. Using data on all contracts awarded to all recipients, we find that the U.S. government has decreased its reliance on developing innovative technologies while increasing its reliance on technologies with existing private market applications. The share of R\&D contract dollars in all contracts awarded to all recipients has fallen from $13 \%$ in 1980 to $8 \%$

\footnotetext{
${ }^{51}$ The samples for Columns 3-4 are restricted to firm-years with one or more publications cited by corporate patents.
} 
in 2020 (Panel A), while the share of commercial contract dollars in all contracts has increased to $27 \%$ in 2020 (Panel B). ${ }^{52}$ In unreported analyses, we find similar evidence in contracts awarded to our panel of firms and across industries.

Historically, the government awarded a majority of downstream procurement contracts noncompetitively to firms that demonstrated strong technical capabilities. Over time, pressures to reduce cost and increase efficiency and transparency in procurement have led to legislative mandates to use competition whenever practicable (Manuel, 2011). As a result, the share of noncompetitive downstream procurement contract dollars (our empirical proxy for guaranteed demand) in all contracts awarded to all recipients has decreased from 57\% in 1980 to 34\% in 2020 (Panel C). In unreported analyses, we find similar evidence in contracts awarded to our panel of firms.

Winning large procurement contracts no longer requires strong scientific capabilities. The share of contract dollars awarded to nonproducers of science in all contracts awarded to panel firms has increased from 6\% in 1980 to $43 \%$ in 2015 (Panel D). Arora et al. (2018) document a decline in the stock market value and the mergers and acquisitions value of scientific capabilities. Our evidence suggests that scientific capabilities may have fallen out of favor with the government as well.

Table 10 documents the same trends using within-firm OLS regressions. The estimates indicate that total contract size has increased by $34 \%$ per decade (Column 1 , p-value $<0.05$ ), driven by non-R\&D and commercial contracts (Columns 2-5). Appendix Table G32 shows that these changes are robust to allowing for nonlinear time effects. Moreover, while firm scientific capabilities - as measured by the stock of corporate publications - have a positive relationship with total contracts (Column 6, p-value < 0.01), this relationship has weakened over time (Column 7, p-value $<0.001$ ).

In summary, the government has decoupled $R \& D$ races from downstream procurement, potentially eroding its ability to incentivize upstream corporate R\&D through the mechanism of guaranteed demand.

\subsection{Implications for Implementation}

Designers of R\&D contests must make choices regarding the strength of incentives, the level of competition, and the structure of contests in a way that balances competing objectives (Bhattacharya, 2021). Because the knowledge developed via R\&D contracts must be implemented downstream, the transfer of knowledge between $\mathrm{R} \& \mathrm{D}$ and production activities is a key consideration in how the government structures its procurement. One solution to overcome implementation challenges is to couple R\&D contracts with downstream procurement contracts.

Over time, we observe increased decoupling. Did implementation become more difficult? Or did the the government maintain the same level of implementation success, either because of better institutions (e.g., small firms, the market for technology) or because R\&D contracts are more downstream and thus easier to implement? We explore these questions by analyzing trends in subcontracting, the composition of R\&D contracts, and contractual deobligations.

\footnotetext{
${ }^{52}$ Commercial contracts are awarded using streamlined acquisition procedures that are designed to resemble transactions in commercial markets.
} 

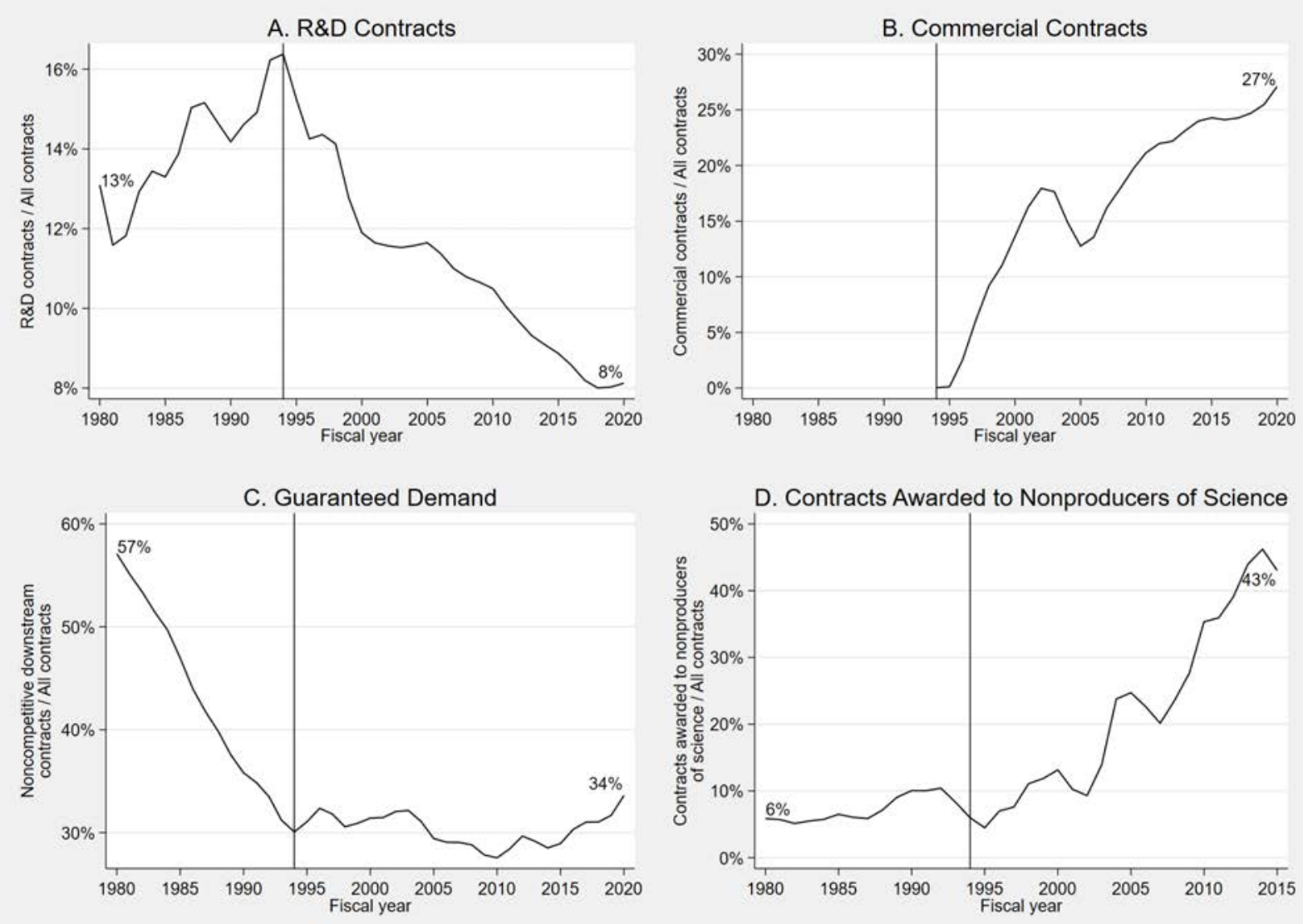

Figure 4: Trends in the Composition of Contracts Over Time

This figure shows changes in the nature and composition of contracts over time. Commercial contracts are awarded using simplified requirements designed to resemble transactions in commercial markets. A firm is a nonproducer of science if its annual number of publications over annual sales is below industry median value. The vertical lines mark the passage of the Federal Acquisition Streamlining Act of 1994.

Figure 5 shows that subcontracting is a major component of federal contracting (Panel A). ${ }^{53}$ Approximately $60 \%$ of all contract dollars awarded in 2021 required a subcontracting plan. Those plans allocated $29 \%$ of prime R\&D contract dollars and $28 \%$ of prime downstream procurement contract dollars to subcontractors. Yet, subcontracting exhibits a negative relationship with competition in procurement (Panel B). When we aggregate downstream procurement contract dollars awarded during 2012-2021 to each four-digit NAICS industry, we find that industries with high rates of competitive procurement have low rates of subcontracting. To the extent that low subcontracting rates indicate challenges in transferring knowledge between R\&D specialists and downstream producers, the rise in competitive procurement may have amplified inefficiencies in project implementation.

\footnotetext{
${ }^{53}$ If a prime contract is expected to exceed $\$ 750,000$ ( $\$ 1.5$ million for construction), then the prime contractor (other than a small business) must typically maintain an acceptable subcontracting plan. This subcontracting plan must be in place prior to contract award, and must include specific dollar and percent goals for subcontracting to small businesses, veteran-owned small businesses, service-disabled veteran-owned small businesses, HUBZone small businesses, small disadvantaged businesses, and women-owned small businesses.
} 
Table 10: Contract Composition and Scientific Capabilities Over Time

\begin{tabular}{|c|c|c|c|c|c|c|c|}
\hline & (1) & $(2)$ & $(3)$ & $(4)$ & $(5)$ & $(6)$ & $(7)$ \\
\hline & \multicolumn{3}{|c|}{ Contract value } & \multicolumn{2}{|c|}{ Contract composition } & \multicolumn{2}{|c|}{ Scientific capabilities } \\
\hline & $\begin{array}{c}\ln (\text { All } \\
\text { contracts) } \\
\text { (OLS: } \\
\text { Within } \\
\text { firms) }\end{array}$ & $\begin{array}{c}\ln (\mathrm{R} \& \mathrm{D} \\
\text { contracts) } \\
\text { (OLS: } \\
\text { Within } \\
\text { firms) }\end{array}$ & $\begin{array}{c}\ln (\text { Comm. } \\
\text { contracts }) \\
\text { (OLS: } \\
\text { Within } \\
\text { firms) }\end{array}$ & $\begin{array}{c}\text { Share R\&D/ } \\
\text { All contracts } \\
\text { (OLS: } \\
\text { Within } \\
\text { firms) }\end{array}$ & $\begin{array}{c}\text { Share comm./ } \\
\text { All contracts } \\
\text { (OLS: } \\
\text { Within } \\
\text { firms) }\end{array}$ & $\begin{array}{c}\ln (\text { All } \\
\text { contracts }) \\
\text { (OLS: } \\
\text { Within } \\
\text { firms) }\end{array}$ & $\begin{array}{c}\ln (\text { All } \\
\text { contracts) } \\
\text { (OLS: } \\
\text { Within } \\
\text { firms) }\end{array}$ \\
\hline Time trend & $\begin{array}{c}0.337 \\
(0.092)\end{array}$ & $\begin{array}{l}-0.115 \\
(0.066)\end{array}$ & $\begin{array}{c}2.635 \\
(0.103)\end{array}$ & $\begin{array}{l}-0.002 \\
(0.018)\end{array}$ & $\begin{array}{c}0.235 \\
(0.022)\end{array}$ & $\begin{array}{c}0.483 \\
(0.111)\end{array}$ & $\begin{array}{c}0.557 \\
(0.133)\end{array}$ \\
\hline $\ln (\text { Publications stock })_{t-1}$ & & & & & & $\begin{array}{c}0.548 \\
(0.119)\end{array}$ & $\begin{array}{c}0.355 \\
(0.142)\end{array}$ \\
\hline Time trend $\times \ln (\text { Publications stock })_{t-1}$ & & & & & & $\begin{array}{l}-0.114 \\
(0.034)\end{array}$ & $\begin{array}{l}-0.083 \\
(0.050)\end{array}$ \\
\hline $\ln (\text { Patents stock })_{t-1}$ & & & & & & & $\begin{array}{c}0.453 \\
(0.143)\end{array}$ \\
\hline Time trend $\times \ln (\text { Patents stock })_{t-1}$ & & & & & & & $\begin{array}{l}-0.064 \\
(0.052)\end{array}$ \\
\hline $\ln (\mathrm{R} \& \mathrm{D} \text { stock })_{t-1}$ & $\begin{array}{c}0.440 \\
(0.058)\end{array}$ & $\begin{array}{c}0.146 \\
(0.037) \\
\end{array}$ & $\begin{array}{c}0.303 \\
(0.060) \\
\end{array}$ & $\begin{array}{c}0.000 \\
(0.007)\end{array}$ & $\begin{array}{l}-0.030 \\
(0.018)\end{array}$ & $\begin{array}{c}0.337 \\
(0.061) \\
\end{array}$ & $\begin{array}{c}0.231 \\
(0.066) \\
\end{array}$ \\
\hline Sample years & $1980-2015$ & $1980-2015$ & 1995-2015 & 1980-2015 & $1995-2015$ & $1980-2015$ & $1980-2015$ \\
\hline Firm fixed effects & Yes & Yes & Yes & Yes & Yes & Yes & Yes \\
\hline Year fixed effects & No & No & No & No & No & No & No \\
\hline Firms & 4,367 & 4,370 & 3,727 & 2,129 & 1,748 & 4,367 & 4,367 \\
\hline Observations & 52,795 & 52,865 & 38,443 & 22,530 & 15,962 & 52,795 & 52,795 \\
\hline Adjusted R-squared & 0.738 & 0.658 & 0.672 & 0.007 & 0.003 & 0.739 & 0.740 \\
\hline
\end{tabular}

Notes: This table presents OLS estimates for changes in procurement contract value, procurement contract composition, and the relationship between government contracts and firm scientific capabilities over time. Time trend is divided by 10. Columns 3 and 5 use data from fiscal years 1995-2015 because the data element that allows us to identify commercial contracts was only introduced following the Federal Acquisition Streamlining Act of 1994. Standard errors (in parentheses) are clustered at the firm level.

Moreover, the composition of $\mathrm{R} \& \mathrm{D}$ contracts has changed over time (Panel $\mathrm{C}$ ). The share of basic/applied research contract dollars in all R\&D contracts has grown from $28 \%$ in 1980 to $51 \%$ in 2020. To the extent that knowledge produced via scientific research is further away from implementation, this reorientation of R\&D contracts toward scientific research and away from development may have made implementing new knowledge into products and services more difficult.

Further evidence comes from contractual deobligations. When awarding a contract, the government records an obligation, which is a promise to spend the money immediately or in the future. A subsequent deobligation is the cancellation or downward adjustment of previously obligated funds. Deobligations can be triggered by contract closeout, termination for default, cause, or convenience, and legal contract cancellation, among other reasons. Over time, the share of deobligated contract dollars has increased, from 3\% in 2001 to 5\% in 2020 (Panel D). In constant 2012 dollars, deobligations were $\$ 8.9$ billion in 2001 and $\$ 31.2$ billion in 2020 . To the extent that deobligations reflect failed project implementation, the rate of project failure may have increased over time.

Table 11 presents within-firm OLS estimates showing that the value of contractual deobligations increases over time (Column 1). More importantly, industries with high decoupled demand (i.e., top 

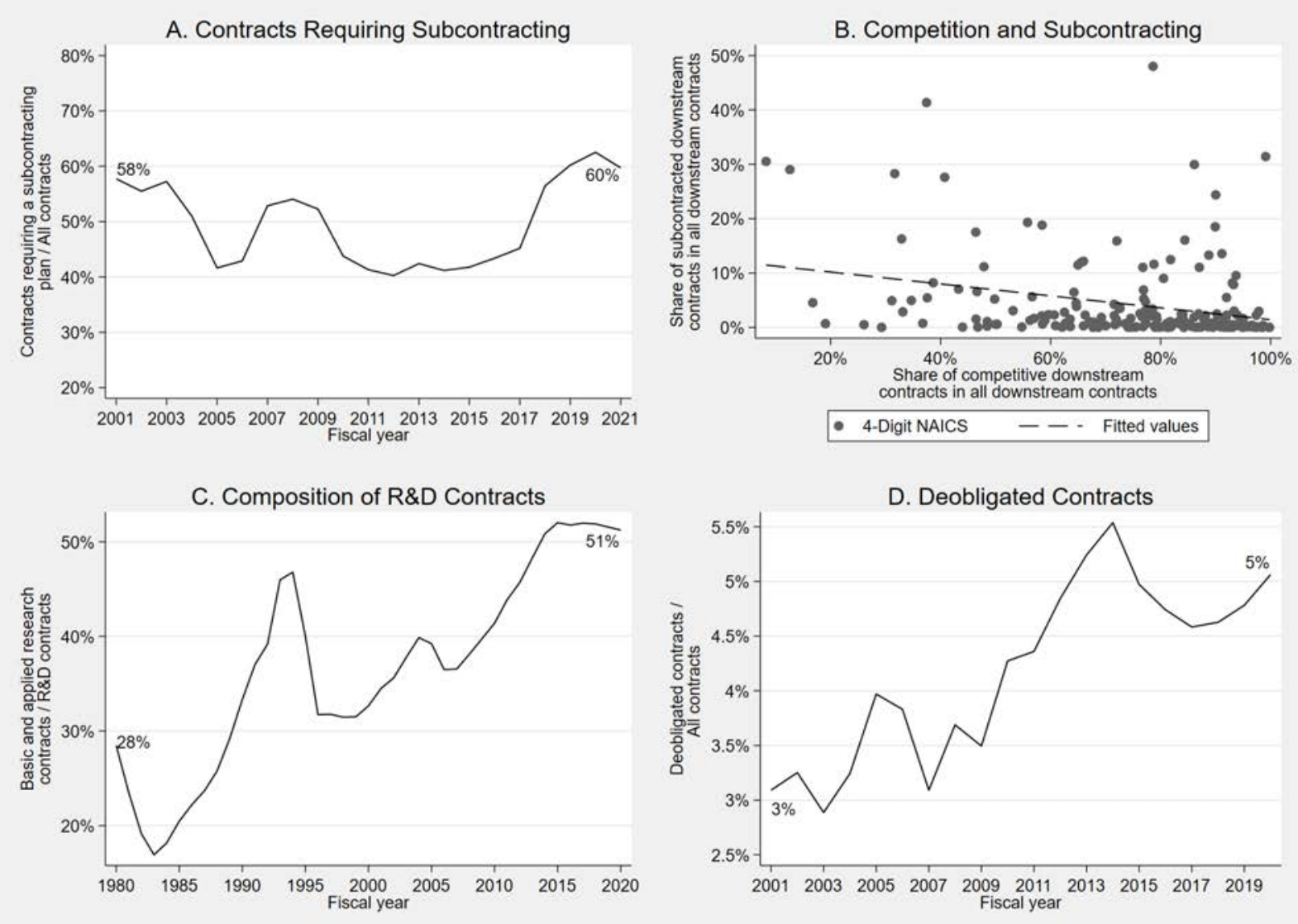

Figure 5: Implementation Challenges

This figure presents trends in the share of contract dollars that require a subcontracting plan (Panel A), the share of R\&D contract dollars awarded for basic and applied research (Panel C), and the share of contractual obligations that are eventually deobligated (Panel D). It also presents the relationship between competition and subcontracting in 4-digit NAICS industries (Panel B).

quartile shares of competitive downstream procurement contracts in all downstream procurement contracts relative to all industries that year) experience larger increases in deobligations over time (Columns 2-3).

In summary, project implementation may have become harder over time, as suggested by (i) the low rate of subcontracting associated with competitive contracts, (ii) the larger allocation of R\&D contract dollars to research projects that are further from implementation, and (iii) the rise in contractual deobligations. Decoupling R\&D races from downstream procurement may have increased transparency and fairness in federal procurement - two explicit objectives of several procurement policy reforms - but may also have adversely affected the implementation of upstream knowledge in downstream procurement. 
Table 11: Deobligations Over Time

\begin{tabular}{|c|c|c|c|}
\hline & (1) & $\begin{array}{c}(2) \\
\ln (\text { Deobligations })\end{array}$ & $(3)$ \\
\hline & $\begin{array}{c}\text { Control for } \\
\text { Obligations } \\
\text { (OLS: } \\
\text { Within firms) }\end{array}$ & $\begin{array}{c}\text { Add } \\
\text { interaction } \\
\text { with indicator } \\
\text { (OLS: } \\
\text { Within firms) }\end{array}$ & $\begin{array}{c}\text { Add } \\
\text { interaction } \\
\text { with share } \\
\text { (OLS: } \\
\text { Within firms) }\end{array}$ \\
\hline Time trend & $\begin{array}{c}0.902 \\
(0.055)\end{array}$ & $\begin{array}{c}0.865 \\
(0.056)\end{array}$ & $\begin{array}{c}0.568 \\
(0.061)\end{array}$ \\
\hline Time trend $\times[$ High decoupled demand $=1]$ & & $\begin{array}{c}0.281 \\
(0.081)\end{array}$ & \\
\hline Time trend $\times$ Share decoupled demand & & & $\begin{array}{c}0.639 \\
(0.076)\end{array}$ \\
\hline High decoupled demand & & $\begin{array}{l}-0.645 \\
(0.169)\end{array}$ & \\
\hline Share decoupled demand & & & $\begin{array}{l}-1.453 \\
(0.173)\end{array}$ \\
\hline $\ln ($ Obligations $)$ & $\begin{array}{c}0.182 \\
(0.007)\end{array}$ & $\begin{array}{c}0.182 \\
(0.007)\end{array}$ & $\begin{array}{c}0.183 \\
(0.007)\end{array}$ \\
\hline $\ln (\text { Sales })_{t-1}$ & $\begin{array}{c}0.229 \\
(0.027)\end{array}$ & $\begin{array}{c}0.231 \\
(0.027)\end{array}$ & $\begin{array}{c}0.224 \\
(0.027)\end{array}$ \\
\hline Sample years & $1980-2015$ & $1980-2015$ & $1980-2015$ \\
\hline Firm fixed effects & Yes & Yes & Yes \\
\hline Year fixed effects & No & No & No \\
\hline Firms & 4,442 & 4,442 & 4,442 \\
\hline Observations & 54,575 & 54,575 & 54,575 \\
\hline Adjusted R-squared & 0.656 & 0.656 & 0.657 \\
\hline
\end{tabular}

Notes: This table presents OLS estimates for changes in contractual deobligations over time. High decoupled demand industries have top-quartile shares of decoupled demand (i.e., competitive downstream procurement contracts in all downstream procurement contracts) relative to all industries that year. Time trend is divided by 10. Standard errors (in parentheses) are clustered at the firm level.

\section{Conclusion}

In this paper we provide evidence suggesting that the anticipation of downstream government procurement encourages corporations to co-invest with the government in upstream R\&D. We document a positive effect of $R \& D$ contracts on publications and employment of renowned scientists ("R"), but not on patents ("D") and show that the effect is strong when downstream procurement is likely to be awarded without competition and when private market incentives are relatively weak. We also show that the effect was stronger before the mid-1990s, when policy reforms such as the Federal Acquisition Streamlining Act of 1994 changed the composition of procurement contracts and significantly decoupled $R \& D$ races from downstream procurement.

We highlight two promising avenues for future work. The first explores the conditions under which it is efficient to couple $R \& D$ races with downstream procurement (i.e., rewarding the firm that develops the upstream technology with the downstream implementation contract). Decoupling $\mathrm{R} \& \mathrm{D}$ from production may lead to inefficiencies in project implementation if there is a high degree 
of complementarity between R\&D and production. In addition, if the government faces contractual problems due to, for instance, the transfer of tacit knowledge and asymmetric information, decoupled projects may be harder to implement (Che et al., 2021). On the other hand, if contractual problems also exist between firms, then R\&D specialists cannot easily partner with downstream producers. In that case, decoupling may increase efficiency if the government subsidizes $R \& D$ and then makes it available for downstream firms. The question then becomes how to trade off the benefits from specialization against the costs from coordination and contracting.

A second promising direction examines the effect of government procurement on small firms. This effect can operate through two main channels. The first is direct, in the form of procurement policies that target small firms through set-asides and subcontracting requirements. ${ }^{54}$ The second is indirect, in the form of investments by large firms that wish to use startup technology to land lucrative downstream procurement contracts. ${ }^{55}$ Studying the implications of government procurement regimes on small firms would deepen our understanding of the effect of public demand on the American innovation ecosystem as a whole.

\section{References}

Adams, J. D., Chiang, E. P., \& Jensen, J. L. (2003). The influence of federal laboratory R\&D on industrial research. Review of Economics and Statistics, 85 (4), 1003-1020.

Arora, A., Belenzon, S., Marx, M., \& Shvadron, D. (2021). (when) does patent protection spur cumulative research within firms? (Tech. Rep. No. 28880). National Bureau of Economic Research. Retrieved from https://www.nber.org/papers/w28880

Arora, A., Belenzon, S., \& Patacconi, A. (2018). The decline of science in corporate R\&D. Strategic Management Journal, 39(1), 3-32.

Arora, A., Belenzon, S., \& Sheer, L. (2021). Knowledge spillovers and corporate investment in scientific research. American Economic Review, 111(3), 871-98.

Arrow, K. (1962). Economic welfare and the allocation of resources for invention. In The rate and direction of inventive activity: Economic and social factors (p. 609-626). National Bureau of Economic Research.

Arve, M., \& Martimort, D. (2016). Dynamic procurement under uncertainty: Optimal design and implications for incomplete contracts. American Economic Review, 106(11), 3238-74.

Azoulay, P., Graff Zivin, J. S., Li, D., \& Sampat, B. N. (2019). Public R\&D investments and private-sector patenting: Evidence from NIH funding rules. The Review of Economic Studies, $86(1), 117-152$.

Bandiera, O., Prat, A., \& Valletti, T. (2009). Active and passive waste in government spending: Evidence from a policy experiment. American Economic Review, 99(4), 1278-1308.

\footnotetext{
${ }^{54}$ The government-wide target for small businesses is at least $23 \%$ of the total value of all prime contracts awarded each year.

${ }^{55}$ For example, in 2011, Lockheed Martin signed a multi-year contract with Canadian startup D-Wave Systems to access the company's quantum annealing technology.
} 
Bartik, T. J. (1991). Who benefits from state and local economic development policies?

Bezos, J. (2021). Open letter to Administrator Nelson. (Available at https://www. blueorigin.com/ news/open-letter-to-administrator-nelson/. Accessed August 10, 2022.)

Bhattacharya, V. (2021). An empirical model of R\&D procurement contests: An analysis of the DOD SBIR program. Econometrica, 89(5), 2189-2224.

Bloom, N., Griffith, R., \& Van Reenen, J. (2002). Do R\&D tax credits work? Evidence from a panel of countries 1979-1997. Journal of Public Economics, 85(1), 1-31.

Bloom, N., Schankerman, M., \& Van Reenen, J. (2013). Identifying technology spillovers and product market rivalry. Econometrica, 81(4), 1347-1393.

Bloom, N., Van Reenen, J., \& Williams, H. (2019). A toolkit of policies to promote innovation. Journal of Economic Perspectives, 33(3), 163-84.

Blundell, R., Griffith, R., \& Van Reenen, J. (1999). Market share, market value and innovation in a panel of British manufacturing firms. The Review of Economic Studies, 66 (3), 529-554.

Che, Y.-K., \& Gale, I. (2003). Optimal design of research contests. American Economic Review, 93(3), 646-671.

Che, Y.-K., Iossa, E., \& Rey, P. (2021). Prizes versus contracts as incentives for innovation. The Review of Economic Studies, 88(5), 2149-2178.

Cohen, W. M., Nelson, R. R., \& Walsh, J. P. (2002). Links and impacts: The influence of public research on industrial R\&D. Management Science, 48(1), 1-23.

Congressional Research Service. (2021). Overview of the federal procurement process and resources (Tech. Rep. No. RS22536). Retrieved from https://fas.org/sgp/crs/misc/RS22536.pdf

Datalab. (2018). Analyst's guide to federal spending data (Version No. 1.2). Retrieved from https:// datalab.usaspending.gov/unstructured-data/resources/analyst-guide.pdf

David, P. A., Hall, B. H., \& Toole, A. A. (2000). Is public R\&D a complement or substitute for private R\&D? a review of the econometric evidence. Research Policy, 29(4-5), 497-529.

Decarolis, F. (2014). Awarding price, contract performance, and bids screening: Evidence from procurement auctions. American Economic Journal: Applied Economics, 6(1), 108-32.

Dugoua, E., Gerarden, T., Myers, K., \& Pless, J. (2022). Creating and steering innovators with supply versus demand policies.

Edler, J., \& Georghiou, L. (2007). Public procurement and innovation-Resurrecting the demand side. Research Policy, 36(7), 949-963.

Federal Acquisition Regulation. (2019). Circumstances permitting other than full and open competition. Subpart 6.302. Retrieved from https://www.acquisition.gov/far/6.302

Hart, O., \& Moore, J. (1988). Incomplete contracts and renegotiation. Econometrica: Journal of the Econometric Society, 755-785.

Hart, O., \& Moore, J. (1999). Foundations of incomplete contracts. The Review of Economic Studies, 66(1), 115-138.

Howell, S. T. (2017). Financing innovation: Evidence from R\&D grants. American Economic Review, 107(4), 1136-64. 
Howell, S. T., Rathje, J., Van Reenen, J., \& Wong, J. (2021). Opening up military innovation: Causal effects of "bottom-up" reforms to U.S. defense research (NBER Working Paper No. 28700). Retrieved from https://www.nber.org/papers/w28700

Kang, K., \& Miller, R. A. (2022). Winning by default: Why is there so little competition in government procurement? The Review of Economic Studies, 89(3), 1495-1556.

Kremer, M., Levin, J., \& Snyder, C. M. (2020). Advance market commitments: Insights from theory and experience. In AEA papers and proceedings (Vol. 110, pp. 269-73). American Economic Association.

Lichtenberg, F. R. (1988). The private R and D investment response to federal design and technical competitions. American Economic Review, 78(3), 550-559.

Liebman, J. B., \& Mahoney, N. (2017). Do expiring budgets lead to wasteful year-end spending? evidence from federal procurement. American Economic Review, 107(11), 3510-49.

Manuel, K. M. (2011). Competition in federal contracting: An overview of the legal requirements (Tech. Rep. No. R40516). Congressional Research Service. Retrieved from https://digital .library .unt.edu/ark:/67531/metadc31464/

Moretti, E., Steinwender, C., \& Van Reenen, J. (2021). The intellectual spoils of war? Defense RED, productivity and international spillovers (NBER Working Paper No. 26483). National Bureau of Economic Research. Retrieved from https://www.nber.org/papers/w26483

Mowery, D. C. (2010). Military R\&D and innovation. In Handbook of the economics of innovation (Vol. 2, pp. 1219-1256). Elsevier.

Mowery, D. C. (2012). Defense-related R\&D as a model for "grand challenges" technology policies. Research Policy, 41(10), 1703-1715.

Myers, K. R., \& Lanahan, L. (2022). Estimating spillovers from publicly funded R\&D: Evidence from the US Department of Energy. American Economic Review, 112(7), 2393-2423.

Nemeh, K. H. (Ed.). (2022). American men 85 women of science: A biographical directory of today's leaders in physical, biological and related sciences (40th ed.). Gale eBooks.

Packalen, M., \& Bhattacharya, J. (2020). NIH funding and the pursuit of edge science. Proceedings of the National Academy of Sciences, 117(22), 12011-12016.

Peters, H. M. (2021). Defense primer: U.S. defense industrial base (Tech. Rep. No. IF10548). Congressional Research Service. Retrieved from https://fas.org/sgp/crs/natsec/IF10548 .pdf

Riordan, M. H., \& Sappington, D. E. (1989). Second sourcing. The RAND Journal of Economics, $41-58$.

Rogerson, W. P. (1989). Profit regulation of defense contractors and prizes for innovation. Journal of Political Economy, 97(6), 1284-1305.

Slavtchev, V., \& Wiederhold, S. (2016). Does the technological content of government demand matter for private R\&D? Evidence from U.S. states. American Economic Journal: Macroeconomics, 8(2), 45-84.

U.K. Department for Business, Innovation \& Skills. (2011). Case study: Forward commit- 
ment procurement (FCP) in practice. (Retrieved from https://www.gov.uk/government/ publications/forward-commitment-procurement-in-practice-case-study. Accessed January 6, 2023.)

U.S. Bureau of Economic Analysis. (2021). Gross Domestic Product: Implicit Price Deflator [GDPDEF]. (Retrieved from FRED, Federal Reserve Bank of St. Louis at https:// fred.stlouisfed.org/series/GDPDEF. Accessed May 9, 2021.)

U.S. Census Bureau. (2019). North American Industry Classification System. Retrieved from https://www . census.gov/eos/www/naics/concordances/concordances.html

U.S. Defense Logistics Agency. (2020). North American Industry Classification System (NAICS) code to Federal Supply Class or Product Service Code. Retrieved from https://www.dla.mil/ SmallBusiness/Resources/

U.S. General Services Administration. (2021). Product and Service Codes (PSC) manual (Tech. Rep. Nos. Fiscal Year 2021 Edition, Version 1.4). Retrieved from https://www.acquisition.gov/ psc-manual

U.S. Government Accountability Office. (1997). Trends in DOD spending, industrial productivity, and competition (Tech. Rep. No. GAO/PEMD-97-3). Retrieved from https://www.gao.gov/ products/GAO/PEMD-97-3

Wallsten, S. J. (2000). The effects of government-industry R\&D programs on private R\&D: The case of the Small Business Innovation Research program. The RAND Journal of Economics, $82-100$.

Weiss, L. (2014). America inc.? Innovation and enterprise in the national security state. Cornell University Press.

Wittie, P. H. (2003). Origins and history of competition requirements in federal government contracting: There's nothing new under the sun. Ninth Annual Federal Procurement Institute. Retrieved from https://www.reedsmith.com/-/media/files/perspectives/ 2003/02/origins-and-history-of-competition-requirements-in/files/origins-and -history-of-competition-requirements-in/fileattachment/wittiepaper.pdf 


\section{ONLINE APPENDIX}

\section{Appendix A Federal Procurement Background}

Procuring products and services for the U.S. government through an advertised, competitive process goes back as far as the Revolutionary War (Wittie, 2003). For example, the Continental Congress passed a resolution on November 20, 1775 to appoint a committee responsible for advertising, receiving proposals, and contracting rations for two new military battalions. In modern times, the Armed Services Procurement Act of 1947 and the Federal Property and Administrative Services Act of 1949 provided comprehensive legislative frameworks for defense and civilian procurement, respectively. Also noteworthy was the Competition in Contracting Act of 1984 that established "full and open competition" as the standard for federal procurement contracts.

\section{A.1 Procurement Process}

The U.S. government is composed of three distinct branches - legislative, executive, and judicialwhose powers and duties are executed through 15 cabinet-level executive departments (Agriculture, Commerce, Defense, Education, Energy, Health and Human Services, Homeland Security, Housing and Urban Development, Interior, Justice, Labor, State, Transportation, Treasury, and Veterans Affairs) and hundreds of independent agencies, government corporations, commissions, and committees. For simplicity, we refer to all these organizations as federal agencies.

The U.S. government's procurement process typically begins with acquisition professionals determining a federal agency's requirements for goods and services and the most appropriate method for purchasing them (Congressional Research Service, 2021). In general, solicitations for contracts above $\$ 25,000$ are posted on the System for Award Management website, SAM.gov. ${ }^{56}$ In response, interested firms prepare and submit offers. ${ }^{57}$ Agency personnel then evaluate the offers using the source selection method and criteria described in the solicitation, in accordance with the Federal Acquisition Regulation (FAR) ${ }^{58}$ The agency awards a contract to a firm only after determining that the company is responsible, meaning it has adequate resources to perform the contract (financial, organizational, technical skill, production facilities, etc.) as well as a satisfactory record of performance, integrity, and business ethics. The next steps include contract performance and administration (e.g., invoice processing and payments, performance monitoring, and contract modifications), followed by contract closeout.

\section{A.2 Policy Changes}

During the Cold War (1948-1989), government procurement focused on achieving and sustaining technological superiority for the purpose of national defense (Weiss, 2014). Federal agencies acquired products and services that met government requirements and specifications and were often unproven in commercial markets (Howell et al., 2021). In the case of defense R\&D, which represented the majority of R\&D contracts, the DoD was often the sole customer (Mowery, 2012). The government's acquisition procedures could be very complex. R\&D races were often used to

\footnotetext{
${ }^{56}$ Other procurement methods include using a government purchase card (i.e., a credit card), placing a task or delivery order against an existing contract, or ordering from a GSA schedule. For R\&D contracting, firms can also submit unsolicited proposals or compete in government-sponsored challenges and prize competitions.

${ }^{57}$ Firms can also participate in government procurement by serving as subcontractors to "prime" contractors.

${ }^{58}$ Almost all federal contracting is governed by the FAR, which consists of Parts 1-53 of Title 48 of the Code of Federal Regulations. The two primary methods of source selection are sealed bidding and negotiated contracting. The latter is typically used for R\&D contracts.
} 
develop new products at the technological leading-edge. Winners were rewarded with noncompetitive downstream procurement contracts. This incentivized firms to perform upstream R\&D and enabled contractors to mitigate the market risk of performing scientific research that didn't yet have commercial applications.

The composition of procurement contracts began shifting toward commercial items and dualuse technologies in the 1980s and accelerated in the 1990s. Numerous policy changes were made in response to the end of the Cold War, increased global trade, constrained defense budgets, and the need to attract nontraditional, innovative suppliers from the much larger commercial markets, especially those in the growing IT sector (Weiss, 2014). Specifically, the U.S. government implemented sweeping patent and intellectual property reforms, acquisition reforms, and organizational reforms. For example, the Bayh-Dole Act of 1980 and its extensions allowed contractors to retain ownership of inventions made with federal funding. The Stevenson-Wydler Technology Innovation Act of 1980 and its extensions gave businesses access to technologies developed in federal laboratories. The Competition in Contracting Act of 1984 mandated that all procurement contracts be awarded based on full and open competition unless regulatory or statutory exclusions applied. The Goldwater-Nichols Department of Defense (DoD) Reorganization Act of 1986 reworked the military command structure and implemented shared procurement across the military branches. The Defense Acquisition Workforce Improvement Act of 1990 established education and training standards for government acquisition professionals. The organizational reforms included the creation of new "hybrid" forms of public-private partnering (Weiss, 2014). One example is the SEMATECH industrial consortium, which was formed in 1987 with funding from the Defense Advanced Research Projects Agency (DARPA) and the involvement of 14 American semiconductor manufacturers.

These policy changes culminated in the Federal Acquisition Streamlining Act of 1994, which enabled simplified acquisition procedures and established a statutory preference for government procurement of commercial items. Procurement dollars were reallocated away from mission-focused technologies that met government specifications and toward dual-use technologies that had both government and commercial potential. Driven by pressures to reduce cost and increase efficiency and transparency, the government began competing with the commercial markets for technologies that already had proven commercial success. 


\section{Appendix B Data Construction}

\section{B.1 Collecting Contracts}

The General Services Administration (GSA) manages the Federal Procurement Data System (FPDS), the central repository of information on U.S. government procurement contracts. The FPDS contains detailed information on all contract transactions above the micro-purchase threshold, which generally ranges from $\$ 2,000$ to $\$ 25,000$, depending on the fiscal year, type of award recipient, and place of performance. ${ }^{59}$ FPDS also maintains the list of valid contracting offices, including their corresponding agencies.

The Federal Funding Accountability and Transparency Act of 2006 (FFATA) required that federal contract, grant, loan, and other financial assistance awards of more than $\$ 25,000$ be displayed on a publicly accessible website. ${ }^{60}$ In response, the U.S. Department of the Treasury developed USAspending.gov as the official public source of federal government contract data (pulled from FPDS) and grant, loan, and other financial assistance data (reported to the Data Act Broker managed by the U.S. Department of the Treasury). The "Custom Award Data" section of the USAspending.gov website allows the public to view and download award transactions for fiscal years starting in 2001. ${ }^{61}$ We used it to download .csv files containing transactions for all prime procurement contracts, awarded by all federal agencies, in all locations, during fiscal years 2001$2021 .{ }^{62}$

We supplemented these data with historical contract transactions from SAM.gov, a website managed by the GSA. The website allows the public to download FPDS award transactions after creating user accounts. We used it to download .csv files containing prime award transactions for procurement contracts awarded by all federal agencies, in all locations, during fiscal years 1980-2000.

To identify the government entity that awarded each procurement contract, acquisition professionals use a four-digit Awarding Agency ID. ${ }^{63}$ The FPDS provides a list of 6,725 contracting offices that were active and valid as of November 2, 2020. These offices are grouped into 227 agencies that are subordinated to 99 first-level "departments." We link each Awarding Agency ID to the corresponding first-level department. Our resulting dataset contains 81.9 million transactions for procurement contracts awarded during fiscal years 1980-2021 by 72 different federal agencies. ${ }^{64}$ As can be seen in Table B1, $12 \%$ of the $\$ 12.5$ trillion in procurement contracts were for R\&D services.

The federal government reports obligations for procurement contracts, not actual outlays. An obligation is the government's promise to spend funds (immediately or later) as a result of entering

\footnotetext{
${ }^{59}$ Other exceptions to the reporting rule include classified contracts, as well as contracts that contain sensitive information about recipients, locations, and operations. For obvious reasons, we cannot estimate the precise value of these unreported contracts.

${ }^{60}$ FFATA was amended by the Government Funding Transparency Act of 2008, which required prime contractors to report details on their first-tier subcontractors, and expanded with the Digital Accountability and Transparency Act of 2014, which established government-wide financial data standards.

${ }^{61} \mathrm{An}$ award usually is made up of a series of transactions, which include the initial award and any subsequent modifications, such as additions or continuations of funding and changes to the scope of work.

${ }^{62}$ Award types include prime awards for contracts, contract indefinite delivery vehicles (IDV), grants, direct payments, loans, insurance, and other financial assistance.

${ }^{63}$ The data also include information about the awarding department/office and funding department/agency/office. However, the procurement contracts are uniquely identified - using the Procurement Instrument Identifier or PIIDat the awarding agency level. Therefore, we use the awarding agency as the primary data element for classifying contracts by source.

${ }^{64}$ Transactions where the Awarding Agency ID (i) was missing or (ii) did not match any of the active agencies were grouped under the "Other" category. For example, the Tennessee Valley Authority is a wholly owned government corporation; while it awarded procurement contracts during 1980-2015, it isn't included in the November 2, 2020, list of active agencies.
} 
into a contract, so long as the agreed-to actions take place. An outlay takes place when those funds are actually paid out to the contractor (Datalab, 2018). If the entire amount initially obligated is not used, the last modification will display a negative dollar amount, called a deobligation. For example, if an initial contract award was for $\$ 100,000$ and an agency only used $\$ 90,000$ of that initial obligation, the last transaction associated with the award would display a deobligation of -\$10,000 (Datalab, 2018). We use changes in the share of deobligated dollars in all contract dollars over time to test the effect of decoupling $R \& D$ races from downstream procurement on project implementation success.

\section{B.2 Matching Contracts to Firms}

We merged the contract data with the panel of U.S.-headquartered publicly traded firms from Arora, Belenzon, and Sheer (2021). We string-matched more than 1.7 million contractor names (including recipients and their parent companies) against almost 60,000 firm names (including ultimate owners and their subsidiaries). ${ }^{65}$ Specifically, we performed vectoral decomposition of firm names using fivecharacter grams. Then, we applied Jaccard similarity scoring. For each contractor, we retained the five best potential matches (in decreasing order of similarity score, as long as the score was above $0.5)$ and completed a four-step process to clean them.

Step 1. We removed unicode and special characters, as well as legal suffixes (e.g., inc, corp, ltd) and conjunctions (e.g., and, on, at) from names, generating "core" versions of contractor and firm names. We reapplied the matching command to evaluate the quality of the match between these "core" names. This time, we used bigrams in the vectoral decomposition and dropped potential "core" matches that had a Jaccard similarity score below 0.65 .

Step 2. We removed generic words from firm names (e.g., terms describing an industry or activity), generating "nongeneric" versions of contractor and firm names. We reapplied the matching command to evaluate the quality of the match between these "nongeneric" names. We used bigrams in the vectoral decomposition and dropped potential "nongeneric" matches that had a Jaccard similarity score below 0.65 .

Step 3. We calculated the Levenshtein distance between "nongeneric" names, and dropped potential matches with an edit distance greater than 15. For each contractor, we retained only the best potential match (in decreasing order of "core" and "nongeneric" similarity scores).

Step 4. We manually cleaned potential matches that had similarity scores below 0.9 , discarding any obvious mismatches.

We obtained a dataset of 37,506 contractor names matched to 12,510 ultimate owner and subsidiary names. Overall, we matched $47 \%$ of all procurement contracts awarded during 1980-2015 to our sample of publicly traded, R\&D performing, U.S.-headquartered firms. We aggregated contracts by firm-year, then allocated contracts matched to subsidiaries to the appropriate ultimate owners using the dynamic match produced by Arora, Belenzon, and Sheer (2021). In summary, we identified 2,590 firms (i.e., ultimate owners) that received a total of $\$ 5.9$ trillion in procurement contract obligations during 1980-2015. Table F15 presents the distribution of firms by two-digit SIC industry.

\section{B.3 Collecting Renowned Scientists' Biographies}

American Men and Women of Science (AMWS) is a biographical directory of renowned North American scientists in the physical, biological, and related sciences (including public health science,

\footnotetext{
${ }^{65}$ We standardized recipient names using the same code used by Arora, Belenzon, and Sheer (2021) to identify the best possible matches to the panel of firms.
} 
engineering, mathematics, statistics, and computer science). Entries include such information as the full name, field of specialty, education, professional experience, memberships, research information, mailing address, fax number, and email address of each entrant. Entrants are scientists who have made significant contributions in their fields, meeting the following criteria:

1. "Distinguished achievement, by reason of experience, training or accomplishment, including contributions to literature, coupled with continuing activity in scientific work; or

2. Research activity of high quality in science as evidenced by publication in reputable scientific journals; or, for those whose work cannot be published due to governmental or industrial security, research activity of high quality in science as evidenced by the judgement of the individual's peers; or

3. Attainment of a position of substantial responsibility requiring scientific training and experience." (Nemeh, 2022, p. vii)

We acquired 17 electronic versions of the AMWS directory, covering editions published from 2005 through 2021. Each edition included the most up-to-date information on living scientists, as well as a reference to the most recent previous edition for deceased scientists. We combined information on the 203,000 living scientists from the 2021 edition with information on the 37,800 deceased scientists from the 2005 -2020 editions. ${ }^{66}$

\section{B.4 Matching Renowned Scientists to Firms}

We matched the renowned scientists from AMWS with the panel of U.S.-headquartered publicly traded firms from Arora, Belenzon, and Sheer (2021). First, we organized the unstructured, paragraph-based AMWS data into a structured, tabular format. A scientists' professional experience typically included multiple positions, where each position was described using the job title, main organization, up to six sub-organizations, and years of employment in the job (e.g., "sr microbiologist, Lilly Res Labs, Eli Lilly \& Co, 1971-1978"). We leveraged the fact that positions were typically separated by semicolons to create separate entries for each position held by a focal scientist. These entries were manually cleaned to address instances of missing semicolons, incomplete years of employment, etc. This process identified approximately 1.3 million positions corresponding to 240,800 scientists. After discarding positions unique to academia (e.g., job titles containing prof, assistant professor, associate professor, editor, lecturer), we retained approximately 840,000 positions in 244,000 unique organizations/sub-organizations.

Second, we string-matched the 244,000 unique organizations/sub-organizations with the almost 60,000 firm names in our panel (including both ultimate owners and their subsidiaries). We calculated the Levenshtein distance between name strings using the Python package TheFuzz. Potential matches with token set ratios below 90 (on a 0-100 scale) were discarded, while the remaining matches were manually checked. We produced a dataset of 12,817 accurate employer organizationfirm name matches. These matches were used to identify 20,552 renowned scientists who worked for our panel of firms, as well as their years of employment.

\footnotetext{
${ }^{66}$ We are indebted to Hansen Zhang, whose work was instrumental to collecting and matching AMWS data.
} 
Table B1: Agencies That Awarded Contracts During 1980-2015

\begin{tabular}{|c|c|c|c|}
\hline $\begin{array}{l}\text { Federal } \\
\text { agency }\end{array}$ & $\begin{array}{l}\text { All contracts } \\
(\$ \mathrm{~mm})\end{array}$ & $\begin{array}{l}\text { Share R\&D / } \\
\text { All contracts }\end{array}$ & $\begin{array}{l}\text { Share matched } \\
\text { to firm panel }\end{array}$ \\
\hline Defense, Department of & $8,621,394$ & $13 \%$ & $55 \%$ \\
\hline Air Force & $2,108,521$ & $21 \%$ & $68 \%$ \\
\hline Navy & $2,578,467$ & $14 \%$ & $69 \%$ \\
\hline Army & $2,527,795$ & $10 \%$ & $42 \%$ \\
\hline Missile Defense Agency (MDA) & 83,913 & $45 \%$ & $97 \%$ \\
\hline Defense Threat Reduction Agency (DTRA) & 23,791 & $57 \%$ & $45 \%$ \\
\hline Defense Adv. Res. Proj. Agency (DARPA) & 13,895 & $91 \%$ & $56 \%$ \\
\hline Other DoD & $1,285,012$ & $1 \%$ & $26 \%$ \\
\hline Energy, Department of & 933,972 & $7 \%$ & $34 \%$ \\
\hline National Aeronautics and Space Admin. & 489,721 & $41 \%$ & $60 \%$ \\
\hline General Services Administration & 296,698 & $<1 \%$ & $23 \%$ \\
\hline Health and Human Services, Department of & 271,837 & $19 \%$ & $34 \%$ \\
\hline Veterans Affairs, Department of & 267,241 & $<1 \%$ & $33 \%$ \\
\hline Homeland Security, Department of & 170,631 & $5 \%$ & $30 \%$ \\
\hline Transportation, Department of & 130,353 & $13 \%$ & $31 \%$ \\
\hline Treasury, Department of the & 128,966 & $1 \%$ & $17 \%$ \\
\hline Justice, Department of & 128,115 & $2 \%$ & $22 \%$ \\
\hline State, Department of & 112,745 & $1 \%$ & $24 \%$ \\
\hline Interior, Department of the & 100,230 & $5 \%$ & $14 \%$ \\
\hline Agriculture, Department of & 86,328 & $1 \%$ & $21 \%$ \\
\hline Agency for International Development & 61,025 & $7 \%$ & $14 \%$ \\
\hline Commerce, Department of & 55,155 & $5 \%$ & $30 \%$ \\
\hline Labor, Department of & 49,668 & $1 \%$ & $9 \%$ \\
\hline Environmental Protection Agency & 40,987 & $6 \%$ & $15 \%$ \\
\hline Education, Department of & 36,075 & $7 \%$ & $32 \%$ \\
\hline Office of Personnel Management & 26,331 & $<1 \%$ & $9 \%$ \\
\hline Housing and Urban Development, Dept. of & 24,869 & $4 \%$ & $21 \%$ \\
\hline Social Security Administration & 20,111 & $<1 \%$ & $41 \%$ \\
\hline National Science Foundation & 10,105 & $28 \%$ & $30 \%$ \\
\hline Smithsonian Institution & 5,308 & $2 \%$ & $5 \%$ \\
\hline Nuclear Regulatory Commission & 4,300 & $10 \%$ & $26 \%$ \\
\hline Securities and Exchange Commission & 3,286 & $1 \%$ & $28 \%$ \\
\hline Pension Benefit Guaranty Corporation & 3,177 & $<1 \%$ & $18 \%$ \\
\hline National Archives and Records Admin. & 2,955 & $<1 \%$ & $27 \%$ \\
\hline Small Business Administration & 2,075 & $1 \%$ & $23 \%$ \\
\hline Peace Corps & 1,893 & $14 \%$ & $11 \%$ \\
\hline United States Agency for Global Media, BBG & 1,764 & $<1 \%$ & $17 \%$ \\
\hline Equal Employment Opportunity Commission & 1,676 & $<1 \%$ & $7 \%$ \\
\hline Federal Communications Commission & 1,258 & $1 \%$ & $12 \%$ \\
\hline Executive Office of the President & 1,175 & $1 \%$ & $36 \%$ \\
\hline Federal Trade Commission & 822 & $1 \%$ & $35 \%$ \\
\hline Corp. for National and Community Service & 788 & $3 \%$ & $8 \%$ \\
\hline Millennium Challenge Corporation & 773 & $14 \%$ & $7 \%$ \\
\hline National Labor Relations Board & 748 & $<1 \%$ & $73 \%$ \\
\hline \multicolumn{4}{|l|}{ Intl. Boundary and Water Commission: } \\
\hline U.S.-Mexico & 609 & $11 \%$ & $4 \%$ \\
\hline Commodity Futures Trading Commission & 516 & $<1 \%$ & $47 \%$ \\
\hline Railroad Retirement Board & 452 & $0 \%$ & $22 \%$ \\
\hline National Gallery of Art & 394 & $38 \%$ & $2 \%$ \\
\hline Government Accountability Office & 382 & $10 \%$ & $8 \%$ \\
\hline
\end{tabular}

Notes: This table displays federal agencies that awarded procurement contracts during 1980-2015. Contracts are deflated using the GDP Implicit Price Deflator to reflect millions of constant 2012 dollars (U.S. Bureau of Economic Analysis, 2021). 
Table B1: Agencies That Awarded Contracts During 1980-2015 (Continued)

\begin{tabular}{|c|c|c|c|}
\hline $\begin{array}{l}\text { Federal } \\
\text { agency }\end{array}$ & $\begin{array}{l}\text { All contracts } \\
(\$ \mathrm{~mm})\end{array}$ & $\begin{array}{l}\text { Share } R \& D / \\
\text { All contracts }\end{array}$ & $\begin{array}{l}\text { Share matched } \\
\text { to firm panel }\end{array}$ \\
\hline Consumer Product Safety Commission & 365 & $2 \%$ & $12 \%$ \\
\hline Court Services and Offender Supervision Agency & 346 & $8 \%$ & $6 \%$ \\
\hline J. F. Kennedy Center for the Performing Arts & 248 & $0 \%$ & $3 \%$ \\
\hline Consumer Financial Protection Bureau & 214 & $0 \%$ & $7 \%$ \\
\hline National Transportation Safety Board & 128 & $1 \%$ & $27 \%$ \\
\hline United States Trade and Development Agency & 125 & $54 \%$ & $4 \%$ \\
\hline Federal Election Commission & 119 & $1 \%$ & $14 \%$ \\
\hline Export-Import Bank of the U.S. & 109 & $2 \%$ & $6 \%$ \\
\hline International Trade Commission & 108 & $<1 \%$ & $17 \%$ \\
\hline Overseas Private Investment Corporation & 90 & $1 \%$ & $6 \%$ \\
\hline National Mediation Board & 71 & $0 \%$ & $6 \%$ \\
\hline National Endowment for the Humanities & 66 & $0 \%$ & $12 \%$ \\
\hline Merit Systems Protection Board & 45 & $8 \%$ & $11 \%$ \\
\hline Defense Nuclear Facilities Safety Board & 44 & $10 \%$ & $3 \%$ \\
\hline Federal Housing Finance Agency & 29 & $0 \%$ & $4 \%$ \\
\hline National Endowment for the Arts & 27 & $2 \%$ & $17 \%$ \\
\hline Selective Service System & 25 & $0 \%$ & $14 \%$ \\
\hline The Institute of Museum and Library Services & 17 & $0 \%$ & $7 \%$ \\
\hline Federal Maritime Commission & 15 & $0 \%$ & $36 \%$ \\
\hline Federal Mediation and Conciliation Service & 15 & $5 \%$ & $9 \%$ \\
\hline Armed Forces Retirement Home & 14 & $0 \%$ & $0 \%$ \\
\hline Federal Labor Relations Authority & 9 & $1 \%$ & $17 \%$ \\
\hline National Capital Planning Commission & 8 & $2 \%$ & $9 \%$ \\
\hline Chemical Safety and Hazard Investigation Board & 7 & $0 \%$ & $8 \%$ \\
\hline $\begin{array}{l}\text { Occupational Safety and Health Review Commis- } \\
\text { sion }\end{array}$ & 5 & $16 \%$ & $18 \%$ \\
\hline \multicolumn{4}{|l|}{ Committee for Purchase From People Who } \\
\hline Are Blind or Severely Disabled & 4 & $0 \%$ & $9 \%$ \\
\hline Election Assistance Commission & 2 & $24 \%$ & $19 \%$ \\
\hline Office of Special Counsel & 2 & $27 \%$ & $41 \%$ \\
\hline Library of Congress & 2 & $0 \%$ & $28 \%$ \\
\hline American Battle Monuments Commission & 0 & $0 \%$ & $50 \%$ \\
\hline Other & 357,695 & $4 \%$ & $21 \%$ \\
\hline Total & $12,456,862$ & $12 \%$ & $47 \%$ \\
\hline
\end{tabular}

Notes: This table displays federal agencies that awarded procurement contracts during 1980-2015. The "Other" category identifies contracts where the awarding federal agency is (i) not identified in the FPDS data or (ii) no longer active as of December 2020. Contracts are deflated using the GDP Implicit Price Deflator to reflect millions of constant 2012 dollars (U.S. Bureau of Economic Analysis, 2021). 


\section{Appendix C Variable Construction}

Table C7 includes definitions and sources for the main variables used in our econometric analyses. The steps used to split procurement contracts into various types (e.g., R\&D vs. non-R\&D), assign contracts to industries, and create variables for several characteristics of science are detailed below.

\section{C.1 Contract Variables}

The types and names of data fields collected in the FPDS have changed over our sample period. For example, prime award data include 169 variables for fiscal years 1980-2000 and 282 variables for fiscal years 2001-2021. To ensure comparability of our analyses over time, we manually mapped the variables obtained from SAM.gov against the corresponding variables obtained from USAspending.gov. To do so, we used the Data Dictionary Crosswalk available from USAspending.gov, as well as the FPDS-NG User's Manual (version 1.5, issued in October 2020) and the FPDS-NG Data Element Dictionary (version 1.4, issued in March 2020) available from FPDS.gov. Table C2 displays the resulting crosswalk between variables.

To describe the products and services acquired in each procurement award, agencies use fourdigit Product and Service Codes (PSC) that mirror the Federal Supply Classification (FSC) codes. ${ }^{67}$ As of March 2020, the PSC/FSC classification consists of 24 service categories (see Table C3) and 78 product groups (see Table $\mathrm{C} 4$ ). The product groups are further subdivided into 645 classes, as defined in the FPDS Product and Service Codes Manual (U.S. General Services Administration, 2021).

We link the PSC/FSC classification to NAICS industries using the crosswalk from the U.S. Defense Logistics Agency (U.S. Defense Logistics Agency, 2020), and then link NAICS industries to SIC industries using the concordances available from the U.S. Census Bureau (U.S. Census Bureau, 2019). This allows us to identify the SIC4 industry for $68 \%$ of procurement contract dollars awarded between 1980 and 2015.

We use the Product or service code field to categorize contracts as either R\&D contracts (service codes starting with the letter A) or non-R\&D contracts (service codes starting with letters B through $\mathrm{Z}$ and product codes starting with any number). ${ }^{68}$ In the procurement contract data, codes for $\mathrm{R} \& \mathrm{D}$ services are composed of two alphabetic and two numeric digits:

- 1st digit: always the letter A to identify R\&D services,

- 2nd digit: alphabetic A to Z to identify the major category,

- 3rd digit: numeric 1 to 9 to identify a subdivision of the major category, and

- 4th digit: numeric 1 to 7 to identify the appropriate stage of R\&D:

1. Basic research,

2. Applied research and exploratory development,

3. Advanced development,

4. Engineering development,

5. Operational systems development,

\footnotetext{
${ }^{67}$ The FSC is a government-wide commodity classification system designed for grouping, classifying, and naming all personal property items.

${ }^{68}$ When a contract action includes more than a single product or service, the awarding agency uses the code corresponding to the predominant product or service.
} 
Table C2: VAriable Crosswalk

\begin{tabular}{|c|c|c|}
\hline SAM.gov variable & USAspending.gov variable & Description \\
\hline contractingagencyid & awarding sub agency code & Awarding Agency ID \\
\hline contractingagencyname & awarding_sub_agency name & Awarding Agency Name \\
\hline contractingofficeid & awarding_office_code & Awarding Office ID \\
\hline contractingofficename & awarding_office_name & Awarding Office Name \\
\hline fundingdepartmentid & funding agency code & Funding Department ID \\
\hline fundingdepartmentname & funding_agency_name & Funding Department Name \\
\hline fundingagencyid & funding_sub_agency_code & Funding Agency ID \\
\hline fundingofficeid & funding_office_code & Funding Office ID \\
\hline piid & award_id_piid & PIID \\
\hline transactionnumber & transaction_number & Transaction Number \\
\hline modificationnumber & modification_number & Modification Number \\
\hline reasonformodification & action_type_code & Reason for Modification \\
\hline referencedidvpiid & parent_award_id_piid & Parent Award ID \\
\hline datesigned & action_date & Date Signed/Action Date \\
\hline actionobligation & federal_action_obligation & Action Obligation \\
\hline baseandalloptionsvaluetotal contr & base and all options value & Base and All Options Value \\
\hline baseandexercisedoptionsvalue & base_and_exercised_options_value & Base and Exercised Options Value \\
\hline vendorname & recipient_-̄name & Recipient Name \\
\hline dunsnumber & recipient_duns & Recipient DUNS \\
\hline globalvendorname & recipient_parent_name & Recipient Parent Name \\
\hline globaldunsnumber & recipient_parent_duns & Recipient Parent DUNS \\
\hline naicscode & naics_code & NAICS Code \\
\hline naicsdescription & naics description & NAICS Description \\
\hline periodofperformancestartdate & period_of_performance_start_date & Period of Performance Start Date \\
\hline estultimatecompletiondate & period_of_performance_potential & Est. Ultimate Completion Date \\
\hline lastdatetoorder & ordering_period_end_date & Last Date to Order \\
\hline completiondate & period_of_performance_current_en & Completion Date \\
\hline productorservicecode & product_or_service_code & Product or Service Code \\
\hline descriptionofrequirement & award__escription & $\begin{array}{l}\text { Description of Requirement/Award De- } \\
\text { scription }\end{array}$ \\
\hline awardtype & award_type_code & Award Type \\
\hline typeofcontract & type_of_contract_pricing_code & Type of Contract \\
\hline $\begin{array}{l}\text { commercialitemacquisition pro- } \\
\text { cedu }\end{array}$ & commercial_item_acquisition_proc & Commercial Item Acquisition Procedures \\
\hline extentcompeted & extent_competed_code & Extent Competed \\
\hline otherthanfullandopen competition & other_than_full_and_open_competi & Other Than Full and Open Competition \\
\hline domesticorforeignentity & domestic or foreign entity_code & Domestic or Foreign Entity \\
\hline evaluatedpreference & evaluated_preference_code & Evaluated Preference \\
\hline fairopportunitylimitedsources & fair_opportunity_limited_sources & Fair Opportunity/Limited Sources \\
\hline foreignfunding & foreign funding & Foreign Funding \\
\hline inherentlygovernmentalfunction & inherently_governmental_function & Inherently Governmental Function \\
\hline isperformancebasedserviceacquisi & performance based service acquis & Is Performance Based Service Acquisition \\
\hline localareasetaside & local_area_set_aside_code & Local Area Set Aside \\
\hline numberofactions & number of actions & Number of Actions \\
\hline samexceptiontype & sam_exception & SAM Exception Type \\
\hline solicitationprocedures & solicitation_procedures_code & Solicitation Procedures \\
\hline typeofsetaside & type_of_set_aside & Type of Set Aside \\
\hline typeofsetasidesource & type_of_set_aside_code & Type of Set Aside Source \\
\hline
\end{tabular}

Notes: This table displays a crosswalk between contract variables available for 1980-2000 from SAM.gov and variables available for 2001-2020 from USAspending.gov.

6. Management and support, and

7. Commercialization (U.S. General Services Administration, 2021).

We use these patterns to categorize $R \& D$ contracts as either research contracts or development 
Table C3: Classification Codes for Services

\begin{tabular}{|c|c|c|c|}
\hline \multicolumn{2}{|c|}{ Code Service category } & \multicolumn{2}{|c|}{ Code Service category } \\
\hline A & Research and development & $\mathrm{N}$ & Installation of equipment \\
\hline B & Special studies and analyses - not R\&D & $\mathrm{P}$ & Salvage services \\
\hline $\mathrm{C}$ & Architect and engineering services - construction & Q & Medical services \\
\hline $\mathrm{D}$ & $\begin{array}{l}\text { Automatic data processing and telecommunication } \\
\text { services }\end{array}$ & $\mathrm{R}$ & $\begin{array}{l}\text { Professional, administrative and management support } \\
\text { services }\end{array}$ \\
\hline $\mathrm{E}$ & Purchase of structures and facilities & $\mathrm{S}$ & Utilities and housekeeping services \\
\hline $\mathrm{F}$ & Natural resources and conservation services & $\mathrm{T}$ & $\begin{array}{l}\text { Photographic, mapping, printing, and publications } \\
\text { services }\end{array}$ \\
\hline G & Social services & $\mathrm{U}$ & Education and training services \\
\hline $\mathrm{H}$ & Quality control, testing, and inspection services & $\mathrm{V}$ & Transportation, travel and relocation services \\
\hline I & Maintenance, repair and rebuilding of equipment & $\mathrm{W}$ & Lease or rental of equipment \\
\hline $\mathrm{K}$ & Modification of equipment & $\mathrm{X}$ & Lease or rental of facilities \\
\hline $\mathrm{L}$ & Technical representative services & $\mathrm{Y}$ & Construction of structures and facilities \\
\hline M & Operation of government owned facility & $\mathrm{Z}$ & Maintenance, repair or alteration of real property \\
\hline
\end{tabular}

Notes: This table displays the 24 high-level categories used to classify the services purchased by the federal government (as of March 2020).

contracts. Specifically, we code the first two stages of R\&D (i.e., basic research and applied research and exploratory development) as upstream R\&D contracts, and the other five stages as downstream R\&D contracts.

We also use the Product or service code field to categorize DoD contracts as either military or nonmilitary based on (i) the Product and Service Codes Manual and (ii) the Government-Wide Category Management Taxonomy. First, the Product and Service Codes Manual classifies R\&D services into the 20 subcategories included in Table C5. Correspondingly, we categorize an R\&D contract from the DoD as military if its PSC code belongs to subcategory AC (R\&D- Defense systems) or AD (R\&D- Defense other), and as nonmilitary otherwise. ${ }^{69}$ Second, the GovernmentWide Category Management Taxonomy classifies downstream procurement contracts into the 10 "common spend" categories and the eight "defense-centric spend" categories included in Table C6. ${ }^{70}$ Likewise, we categorize a downstream procurement contract from the DoD as military if its PSC code belongs to a defense-centric spend category, and as nonmilitary otherwise.

We use the Commercial items acquisition procedures field to categorized non-R\&D contracts into either commercial contracts or noncommercial contracts. ${ }^{71}$ Contracts were awarded using commercial item procedures only after the passage of the Federal Acquisition Streamlining Act of 1994. Therefore, our data separating commercial vs. noncommercial contracts only span fiscal years 1995-2015. While some R\&D service contracts were awarded using streamlined commercial item procedures, they represent less than $1 \%$ of the value of all $R \& D$ contracts awarded to sample firms. Therefore, we do not break down $\mathrm{R} \& \mathrm{D}$ contracts into commercial vs. noncommercial contracts.

We use the Extent competed field to distinguish contracts that were awarded competitively from those awarded noncompetitively. In general, federal agencies are required to use full and open competition when awarding procurement contracts. Competitive procedures include sealed bids,

\footnotetext{
${ }^{69}$ All contracts awarded by other agencies than the DoD are nonmilitary by definition.

${ }^{70}$ Category management is the practice of buying common products and services as a unified federal government enterprise to eliminate redundancies and improve the efficiency and effectiveness of acquisition activities. The Government-Wide Category Management Taxonomy was downloaded from https://hallways.cap.gsa.gov/app/\#/ gateway/category-management/8825/government-wide-category-taxonomy on September 22, 2022.

${ }^{71}$ This field indicates whether the solicitation used the special requirements for the acquisition of commercial items, supplies, or services. Those requirements are intended to more closely resemble the commercial markets as defined by the Federal Acquisition Regulation Part 12.
} 
Table C4: Classification Codes for Products

\begin{tabular}{|c|c|c|c|}
\hline \multicolumn{2}{|c|}{ Code Product group } & \multicolumn{2}{|c|}{ Code Product group } \\
\hline 10 & Weapons & 53 & Hardware and Abrasives \\
\hline 11 & Nuclear Ordinance & 54 & Prefabricated Structures and Scaffolding \\
\hline 12 & Fire Control Equipment & 55 & Lumber, Millwork, Plywood, and Veneer \\
\hline 13 & Ammunition and Explosives & 56 & Construction and Building Materials \\
\hline 14 & Guided Missiles & 58 & $\begin{array}{l}\text { Communications, Detection and Coherent Radiation } \\
\text { Equipment }\end{array}$ \\
\hline 15 & Aircraft and Airframe Structural Components & 59 & Electrical and Electronic Equipment Components \\
\hline 16 & Aerospace Craft Components and Accessories & 60 & $\begin{array}{l}\text { Fiber Optics Materials and Components, Assemblies } \\
\text { and Accessories }\end{array}$ \\
\hline 17 & $\begin{array}{l}\text { Aerospace Craft Launching, Landing, and Ground } \\
\text { Handling Equipment }\end{array}$ & 61 & $\begin{array}{l}\text { Electric Wire, and Power and Distribution Equip- } \\
\text { ment }\end{array}$ \\
\hline 18 & Space Vehicles & 62 & Lighting Fixtures and Lamps \\
\hline 19 & Ships, Small Craft, Pontoons, and Floating Docks & 63 & Alarm, Signal and Security Detection Systems \\
\hline 20 & Ship and Marine Equipment & 65 & $\begin{array}{l}\text { Medical, Dental, and Veterinary Equipment and Sup- } \\
\text { plies }\end{array}$ \\
\hline 22 & Railway Equipment & 66 & Instruments and Laboratory Equipment \\
\hline 23 & $\begin{array}{l}\text { Ground Effect Vehicles, Motor Vehicles, Trailers, and } \\
\text { Cycles }\end{array}$ & 67 & Photographic Equipment \\
\hline 24 & Tractors & 68 & Chemicals and Chemical Products \\
\hline 25 & Vehicular Equipment Components & 69 & Training Aids and Devices \\
\hline 26 & Tires and Tubes & 70 & $\begin{array}{l}\text { ADP Equipment Software, Supplies and Support } \\
\text { Equipment }\end{array}$ \\
\hline 28 & Engines, Turbines, and Components & 71 & Furniture \\
\hline 29 & Engine Accessories & 72 & $\begin{array}{l}\text { Household and Commercial Furnishings and Appli- } \\
\text { ances }\end{array}$ \\
\hline 30 & Mechanical Power Transmission Equipment & 73 & Food Preparation and Serving Equipment \\
\hline 31 & Bearings & 74 & Office Machines \\
\hline 32 & Woodworking Machinery and Equipment & 75 & Office Supplies and Devices \\
\hline 34 & Metalworking Machinery & 76 & Books, Maps, and Other Publications \\
\hline 35 & Service and Trade Equipment & 77 & $\begin{array}{l}\text { Musical Instruments, Phonographs, and Home Ra- } \\
\text { dios }\end{array}$ \\
\hline 36 & Special Industry Machinery & 78 & Recreational and Athletic Equipment \\
\hline 37 & Agricultural Machinery and Equipment & 79 & Cleaning Equipment and Supplies \\
\hline 38 & $\begin{array}{l}\text { Construction, Mining, Excavating, and Highway } \\
\text { Maintenance Equipment }\end{array}$ & 80 & Brushes, Paints, Sealers, and Adhesives \\
\hline 39 & Materials Handling Equipment & 81 & Containers, Packaging, and Packing Supplies \\
\hline 40 & Rope, Cable, Chain, and Fittings & 83 & $\begin{array}{l}\text { Textiles, Leather, Furs, Apparel and Shoes, Tents, } \\
\text { Flags }\end{array}$ \\
\hline 41 & $\begin{array}{l}\text { Refrigeration, Air Conditioning and Air Circulating } \\
\text { Equipment }\end{array}$ & 84 & Clothing, Individual Equipment, and Insignia \\
\hline 42 & Fire Fighting, Rescue, and Safety Equipment & 85 & Toiletries \\
\hline 43 & Pumps and Compressors & 87 & Agricultural Supplies \\
\hline 44 & $\begin{array}{l}\text { Furnace, Steam Plant, and Drying Equip, Nuclear } \\
\text { Reactors }\end{array}$ & 88 & Live Animals \\
\hline 45 & Plumbing, Heating and Sanitation Equipment & 89 & Subsistence (Food) \\
\hline 46 & $\begin{array}{l}\text { Water Purification and Sewage Treatment Equip- } \\
\text { ment }\end{array}$ & 91 & Fuels, Lubricants, Oils, and Waxes \\
\hline 47 & Pipe, Tubing, Hose, and Fittings & 93 & Nonmetallic Fabricated Materials \\
\hline 48 & Valves & 94 & Nonmetallic Crude Materials \\
\hline 49 & Maintenance and Repair Shop Equipment & 95 & Metal Bars, Sheets, and Shapes \\
\hline 51 & Hand Tools & 96 & Ores, Minerals, and Their Primary Products \\
\hline 52 & Measuring Tools & 99 & Miscellaneous \\
\hline
\end{tabular}

Notes: This table displays the 78 high-level groups used to classify the products purchased by the federal government (as of March 2020). Groups 21, 27, 33, 50, 57, 64, 82, 86, 90, 92, 97, and 98 are unassigned. 
Table C5: Classification Codes for R\&D Services

\begin{tabular}{|c|c|}
\hline CodeSubcategory & CodeSubcategory \\
\hline AA R\&D- Agriculture & AL R\&D- Income security \\
\hline $\mathrm{AB} \quad \mathrm{R} \& \mathrm{D}-$ Community service/development & AM R\&D- International affairs and cooperation \\
\hline AC R\&D- Defense systems & AN R\&D- Medical \\
\hline AD R\&D- Defense other & AP R\&D- Natural resource \\
\hline AE R\&D- Economic growth & AQ R\&D- Social services \\
\hline AF R\&D- Education & AR R\&D- Space \\
\hline AG R\&D- Energy & AS R\&D- Modal transportation \\
\hline AH R\&D- Environmental protection & AT R\&D- Other transportation \\
\hline AJ R\&D- General science/technology & AV R\&D- Mining \\
\hline AK R\&D- Housing & AZ R\&D- Other research and development \\
\hline
\end{tabular}

Notes: This table displays the 20 sub-categories used to classify the R\&D services purchased by the federal government (as of March 2020).

\section{Table C6: Government-Wide Category Management Taxonomy}

\begin{tabular}{lll}
\hline Type of spend & Category & PSC example \\
\hline Common spend & Facilities and construction & 3710 Soil preparation equipment \\
& Human capital & U001 Education/training- Lectures \\
& Industrial products and services & 3010 Torque converters and speed changers \\
& Information technology & 5820 Radio and television communication \\
& equipment, except airborne \\
& Medical & 6505 Drugs and biologicals \\
Office management & 3610 Printing, duplicating, and bookbind- \\
& ing equipment \\
Professional services & B502 Special studies/analysis- Air quality \\
Security and protection & 5660 Fencing, fences, gates and components \\
Transportation and logistical services & 2210 Locomotives \\
Travel & V302 Transportation/travel/relocation- \\
& Relocation: travel agent \\
\hline Defense-centric spend Aircraft, ships/submarines, and land vehi- & 1510 Aircraft, fixed wing \\
cles & \\
Clothing, textiles, and subsistence services & 8970 Composite food packages \\
and equipment & \\
Electronic and communication equipment & 5825 Radio navigation equipment, except \\
& airborne \\
Electronic and communication services & H158 Quality control- Communication, de- \\
& tection, and coherent radiation equipment \\
Equipment related services & H110 Quality control- weapons \\
Miscellaneous services and equipment & H176 Quality control- Books, maps, and \\
& other publications \\
Sustainment services and equipment & 1550 Unmanned aircraft \\
Weapons and ammunition & 1015 Guns, 75mm through 125mm \\
\hline
\end{tabular}

Notes: This table displays the common spend and defense-centric spend categories included in the Government-Wide Category Management Taxonomy (as of March 2020).

competitive proposals, or a combination of competitive procedures. However, the Competition in Contracting Act of 1984 authorized noncompetitive contracting under certain conditions. ${ }^{72}$

\footnotetext{
${ }^{72}$ FAR currently identifies seven exceptions to full and open competition: (i) only one responsible source and no other supplies or services will satisfy agency requirements; (ii) unusual and compelling urgency; (iii) industrial
} 
We use the Award description text field to correctly identify contractual deobligations. Deobligations represent cancellations or downward adjustments of previously obligated funds (e.g., due to default or closeout). Yet not all negative transactions are meaninful deobligations; some are simply corrections of clerical errors. For example, an acquisition professional may omit the decimal point when recording an obligation for $\$ 10$ million, turning it into $\$ 1$ billion. To correct this error, the professional would subsequently record a deobligation for $-\$ 990$ million and add a comment about it in the Award description field. We identify all transactions described using the keyword "correct," "error," "mistake," "inadvertently," or "accidentally" and exclude them from deobligation analyses. ${ }^{73}$

Table C7 summarizes the definitions and data sources for the main variables used in our econometric analyses.

mobilization; engineering, developmental, or research capability; or expert services; (iv) international agreement; (v) authorized or required by statute; (vi) national security; and (vii) public interest (Federal Acquisition Regulation, 2019).

${ }^{73}$ The Award description field is consistently available for contract transactions made during 2001-2015, but not during 1980-2000. 
Table C7: VARIABle Definitions

\begin{tabular}{|c|c|c|}
\hline Variable & Definition & Source \\
\hline Publications & $\begin{array}{l}\text { Sum of scholarly, peer-reviewed publications that have at least one } \\
\text { author affiliated with the focal firm and were published in the focal } \\
\text { year. Appendix C details how we split the publication flow into In- } \\
\text { ternal use vs. No internal use (to capture the focal firm's own use } \\
\text { of science), High rival use vs. Low rival use (to capture product- } \\
\text { market rivals' use of science), and High protection publications vs. } \\
\text { Low protection publications (to capture the scope of protection of- } \\
\text { fered by the focal firm's own patents). }\end{array}$ & $\begin{array}{l}\text { Clarivate Analytics' } \\
\text { Web of Science (Arora, } \\
\text { Belenzon, \& Sheer, } \\
2021)\end{array}$ \\
\hline $\begin{array}{l}\text { Publications } \\
\text { stock }\end{array}$ & $\begin{array}{l}\text { Calculated using a perpetual inventory method with a } 15 \% \text { depre- } \\
\text { ciation rate (Hall et al., 2005), such that the stock in year } t \text { is } \\
\text { Publications stock } k_{t}=\text { Publications } s_{t}+(1-\delta) \text { Publications stock } k_{t-1} \text {, } \\
\text { where } \delta=0.15 \text {. }\end{array}$ & \\
\hline $\begin{array}{l}\text { Renowned } \\
\text { scientists }\end{array}$ & $\begin{array}{l}\text { Sum of renowned scientists employed by the focal firm in the focal } \\
\text { year. }\end{array}$ & $\begin{array}{l}\text { American Men } \\
\text { Women of Science }\end{array}$ \\
\hline $\begin{array}{l}\text { Award-winning } \\
\text { renowned } \\
\text { scientists }\end{array}$ & $\begin{array}{l}\text { Sum of award-winning renowned scientists employed by the focal } \\
\text { firm in the focal year. }\end{array}$ & $\begin{array}{l}\text { American Men } \\
\text { Women of Science }\end{array}$ \\
\hline Patents & $\begin{array}{l}\text { Sum of patents granted by the U.S. Patent and Trademark Office } \\
\text { to the focal firm in the focal year. }\end{array}$ & $\begin{array}{lr}\text { European } & \text { Patent } \\
\text { Office's } & \text { PATSTAT } \\
\text { database } & \text { (Arora, Be- } \\
\text { lenzon, \& Sheer, 2021) }\end{array}$ \\
\hline All contracts & Sum of all contract awards associated with a firm-year $(\$ \mathrm{~mm})$. & $\begin{array}{l}\text { USAspending.gov, } \\
\text { beta.SAM.gov }\end{array}$ \\
\hline Deobligations & $\begin{array}{l}\text { Sum of all negative contract modifications associated with a firm- } \\
\text { year }(\$ \mathrm{~mm}) \text {. }\end{array}$ & $\begin{array}{l}\text { USAspending.gov, } \\
\text { beta.SAM.gov }\end{array}$ \\
\hline R\&D contracts & Sum of R\&D contract awards associated with a firm-year $(\$ \mathrm{~mm})$. & \\
\hline Non-R\&D contracts & $\begin{array}{l}\text { Sum of non-R\&D contract awards associated with a firm-year ( } \$ \\
\mathrm{~mm}) \text {. }\end{array}$ & \\
\hline Commercial contracts & $\begin{array}{l}\text { Sum of commercial contract awards associated with a firm-year (\$ } \\
\mathrm{mm}) \text {. }\end{array}$ & \\
\hline $\begin{array}{l}\text { Noncommercial } \\
\text { contracts }\end{array}$ & $\begin{array}{l}\text { Sum of noncommercial contract awards associated with a firm-year } \\
(\$ \mathrm{~mm}) \text {. }\end{array}$ & \\
\hline All grants & $\begin{array}{l}\text { Sum of all project grants and cooperative agreements associated } \\
\text { with a firm-year }(\$ \mathrm{~mm})\end{array}$ & USAspending.gov \\
\hline Time trend & Focal year minus 1980 (in decennial units). & \\
\hline Sales & Sales for the focal firm-year $(\$ \mathrm{~mm})$. & $\begin{array}{l}\text { Standard \& Poor's } \\
\text { Compustat } \quad \text { North } \\
\text { America (Arora, Belen- } \\
\text { zon, \& Sheer, 2021) }\end{array}$ \\
\hline $\begin{array}{l}\mathrm{R} \& \mathrm{D} \\
\text { expenditures }\end{array}$ & R\&D expenditures for the focal firm-year $(\$ \mathrm{~mm})$. & $\begin{array}{l}\text { Standard \& } \begin{array}{l}\text { Poor's } \\
\text { Compustat }\end{array} \text { North } \\
\text { America (Arora, Belen- } \\
\text { zon, \& Sheer, 2021) }\end{array}$ \\
\hline R\&D stock & $\begin{array}{l}\text { Calculated using a perpetual inventory method with a } 15 \% \text { de- } \\
\text { preciation rate, such that the stock in year } t \text { is } R \& D \text { stock } k_{t}= \\
R \& D \text { expenditure } s_{t}+(1-\delta) R \& D \text { stock } k_{t-1} \text {, where the focal firm's } \\
R \& D \text { expenditures in year } t \text { are based on Compustat data and } \\
\delta=0.15 \text {. Expressed in } \$ \mathrm{~mm} \text {. }\end{array}$ & $\begin{array}{l}\text { Standard \& Poor's } \\
\text { Compustat } \quad \text { North } \\
\text { America (Arora, Belen- } \\
\text { zon, \& Sheer, 2021) }\end{array}$ \\
\hline
\end{tabular}

Notes: This table displays definitions and sources for the variables used in our econometric analyses. Dollar values are deflated using the GDP Implicit Price Deflator to reflect constant 2012 dollars (U.S. Bureau of Economic Analysis, 2021). 
Table C7: Variable Definitions (Continued)

\begin{tabular}{|c|c|}
\hline Variable & Definition \\
\hline \multicolumn{2}{|c|}{ Industry R\&D funding } \\
\hline $\begin{array}{l}\text { Agency R\&D } \\
\text { budget }\end{array}$ & 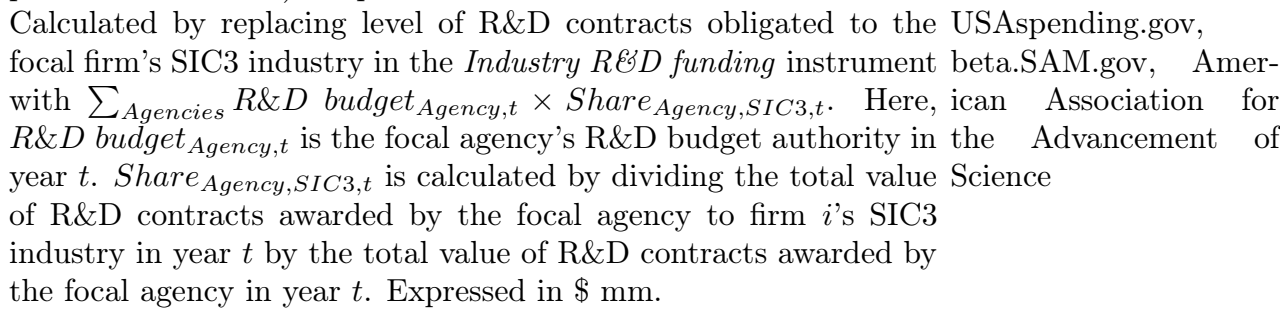 \\
\hline $\begin{array}{l}\text { Windfall- } \\
\text { predicted R\&D } \\
\text { budget }\end{array}$ & 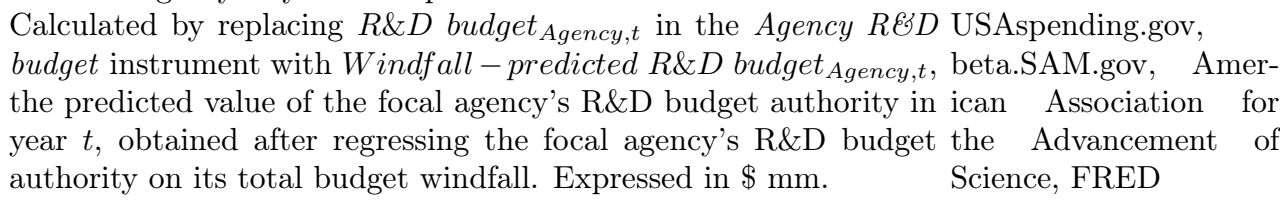 \\
\hline $\begin{array}{l}\text { PSC R\&D } \\
\text { funding }\end{array}$ & $\begin{array}{l}\text { Calculated as } \sum_{P S C s} R \& D \text { contracts } s_{P S C, t} \times \text { Share }_{i, P S C} \text {. Here, USAspending.gov, } \\
R \& D \text { contracts } s_{P S C, t} \text { is the total value of all R\&D contracts beta.SAM.gov } \\
\text { awarded by all federal agencies to purchase the focal PSC in year } t . \\
S_{\text {thare }}, P S C \text { is calculated by dividing the total value of } \mathrm{R} \& \mathrm{D} \text { con- } \\
\text { tracts for the focal PSC awarded to firm } i \text { during } 1980-2015 \text { by the } \\
\text { total value of R\&D contracts awarded to firm } i \text { during } 1980-2015 \text {. } \\
\text { Expressed in } \$ \mathrm{~mm} \text {. }\end{array}$ \\
\hline Cold War shock & $\begin{array}{l}\text { Calculated using the difference in average contract values between USAspending.gov, } \\
\text { pre (1986-1988) and post (1990-1992) periods for each SIC4 indus- beta.SAM.gov, Stan- } \\
\text { try, weighted by the focal firm's sales exposure to different SIC4 dard \& Poor's Compu- } \\
\text { industries. Expressed in } \$ \text { mm. The sales exposure is calculated as stat North America } \\
\text { the share of the focal firm's sales during 1982-1985 that came from } \\
\text { each SIC4 industry. }\end{array}$ \\
\hline $\begin{array}{l}\text { Global War on } \\
\text { Terrorism shock }\end{array}$ & $\begin{array}{l}\text { Calculated using the difference in contract values between pre USAspending.gov, } \\
(2000) \text { and post (2004) periods for each SIC4 industry, weighted beta.SAM.gov, Stan- } \\
\text { by the focal firm's sales exposure to different SIC4 industries. Ex- dard \& Poor's Compu- } \\
\text { pressed in } \$ \text { mm. The sales exposure is calculated as the share of stat North America } \\
\text { the focal firm's sales during } 1994-1997 \text { that came from each SIC4 } \\
\text { industry. }\end{array}$ \\
\hline $\begin{array}{l}\text { Financial Crisis } \\
\text { shock }\end{array}$ & $\begin{array}{l}\text { Calculated using the difference in contract values between pre USAspending.gov, } \\
\text { (2007) and post (2008) periods for each SIC4 industry, weighted beta.SAM.gov, Stan- } \\
\text { by the focal firm's sales exposure to different SIC4 industries. Ex- dard \& Poor's Compu- } \\
\text { pressed in } \$ \text { mm. The sales exposure is calculated as the share of stat North America } \\
\text { the focal firm's sales during 2000-2003 that came from each SIC4 } \\
\text { industry. }\end{array}$ \\
\hline
\end{tabular}

Notes: This table displays definitions and sources for the variables used in our econometric analyses. Dollar values are deflated using the GDP Implicit Price Deflator to reflect constant 2012 dollars (U.S. Bureau of Economic Analysis, 2021). 


\section{C.2 Market Incentives Variables}

We measure several characteristics of corporate science that allow us to estimate the effect of procurement contracts on corporate R\&D under different private market conditions.

First, we split the annual publication flow into (i) publications cited by the firm's own patents and (ii) publications not cited by the firm's own patents. We use the non-patent literature citations file from Arora, Belenzon, and Sheer (2021) to do so. The number of unique publications that receive one or more citations from the firm's own patents is aggregated at the firm-year level into the variable Internal use publications. The remaining annual publication flow is captured in the variable No internal use publications.

Second, we identify publications that are cited by one or more patents assigned to other panel firms. We split a firm's annual publication flow into (i) publications with low rival use and (ii) publications with high rival use. To do so, we use a measure of the product-market rivalry between the publishing firm and the patenting firms (up to three corporate assignees per patent) sourced from Arora, Belenzon, and Sheer (2021). Product-market rivalry is calculated as the Mahalanobis similarity of vectors representing the shares of industry segment sales for each pair of firms. A publication has high rival use if its highest similarity score is in the top quartile of the distribution of similarity scores. The number of unique publications that have high rival use is aggregated at the firm-year level into the variable High rival use publications. The remaining annual publication flow is captured in the variable Low rival use publications.

Third, we split the annual publication flow into (i) publications that have low patent protection and (ii) publications that have high patent protection. We use a measure of the textual similarity between Web of Science publications (abstract and title) and USPTO patents (claims) from Arora, Belenzon, Marx, and Shvadron (2021). For each corporate publication published between 1980 and 2015, we retain up to five of the most similar granted patents. We identify which of those patents are owned by the publishing firm and retain the top matching publication-patent pair. Publications with proximity scores above the median (relative to the publication year) are coded as "protected" by a patent, while those with scores below the median and those unmatched to firm patents are coded as "unprotected" by a patent. ${ }^{74}$ The number of unique publications that are "protected" by the firm's patents is aggregated at the firm-year level into the variable High protection publications. The remaining annual publication flow is captured in the variable Low protection publications.

\footnotetext{
${ }^{74}$ Our choice of cutoff - the median publication-patent proximity score for all the publications published by sample firms in a given year - allows us to take into consideration how the proximity between publications and patents changes over time.
} 


\section{Appendix D Instrumental Variable Estimation}

\section{D.1 Industry R\&D Funding}

Our first instrument exploits variation in aggregate industry R\&D contracts to predict $R \& D$ contracts awarded to a focal firm. It is important to recognize that R\&D contracts awarded to a firm's SIC4 industry may still be endogenous (e.g., when a firm dominates its SIC4 industry, it is possible that industry $R \& D$ contracts and firm $R \& D$ activity respond to the same technology shocks). To mitigate this concern, we take advantage of changes in $R \& D$ funding at a higher level of aggregation, the firm's SIC3 industry. We "distribute" these changes across SIC4 industries according to time-invariant industry shares, closely following Moretti et al. (2021). Doing so lowers the power of our instrument in the first stage, but increases its validity.

We construct our instrumental variable (IV) in three stages. First, we identify the SIC4 industry for each procurement contract awarded during 1980-2015 (not just those matched to sample firms). For transactions that do not list the recipient firm's NAICS code, we use the Product or service code (PSC) field and the PSC-to-NAICS crosswalk from the U.S. Defense Logistics Agency to identify the NAICS code. Then, we use the NAICS-to-SIC concordances available from the U.S. Census Bureau to identify the SIC4 code. We aggregate all R\&D contracts awarded to all firms (not just our panel firms) at the SIC4-year and SIC3-year levels, respectively.

Second, we calculate the share of R\&D contracts awarded to the SIC4 industry relative to the $\mathrm{R} \& \mathrm{D}$ contracts awarded to the SIC3 industry that contains it. Specifically, we divide the total value of R\&D contracts awarded to the SIC4 industry during 1980-2015 by the total value of R\&D contracts awarded to the higher-level SIC3 industry during 1980-2015.

Third, we calculate the instrument as Industry $R \& D$ funding ${ }_{i, t}=\left(\right.$ Industry $R \& D^{2}$ contracts $_{S I C 3, t}-$ Firm $_{R} \& D$ contract $\left._{i, t}\right) \times$ Industry share $_{S I C 4, S I C 3}$. Industry $R \& D$ contracts $_{S I C 3, t}$ is the total value of all $\mathrm{R} \& \mathrm{D}$ contracts awarded by federal agencies to the focal firm's SIC3 industry in year $t$. Firm R\&D contracts $_{i, t}$ is the value R\&D contracts awarded to the focal firm in year $t$. The reason for excluding firm R\&D contracts from the construction of the IV is to avoid a mechanical correlation between the endogenous variable we want to instrument and the instrument itself. Industry share $_{S I C 4, S I C 3}$ is calculated by dividing the total value of R\&D contracts awarded to the focal firm's SIC4 industry during 1980-2015 by the total value of R\&D contracts awarded to the focal firm's higher-level SIC3 industry during 1980-2015. We use a time-invariant share because it allows us to smooth out year-to-year variation in the R\&D contracts awarded to the SIC4 industry.

Take Boeing as an example. In 2012, Boeing's SIC3 industry (372 Aircraft and Parts) received $\$ 13.7$ billion in R\&D contracts, including almost $\$ 3.6$ billion for Boeing. Over the sample period of 1980-2015, Boeing's SIC4 industry (3721 Aircraft) received 99\% of the R\&D contracts awarded to its SIC3 industry (372 Aircraft and Parts). The instrument for Boeing in 2012 was calculated as $(13.7-3.6) \times .99=10$ (in $\$$ billions).

Using this industry R\&D funding measure (rather than the total value of $R \& D$ contracts awarded to the firm's SIC4 industry in year $t$ ) strengthens the validity of our instrument because it makes it less likely to be related to the focal firm's idiosyncratic technical opportunities.

\section{D.2 Cold War Shock}

An alternative instrument uses changes between the pre- and post- Soviet collapse periods in industry-level contracts to predict firm-level R\&D contracts during 1995-2015 (see Figure D1 for the associated timeline). Because this instrument does not vary within firms (i.e., there is only one change per firm), we cannot use firm fixed effects. Instead, we follow Blundell, Griffith, and 
Van Reenen (1999) and include the pre-sample mean of the dependent variable as a separate control for time-invariant firm heterogeneity. Many sample firms operate in multiple business segments, so they were affected by changes in procurement contracts across multiple industries. To estimate the "average" shock experienced by each firm, we use the shares of firm sales in each industry as weights. We build Cold War shock $k_{i}=\sum_{\text {Industries }} \Delta$ Contracts $_{\text {SIC } 4} \times$ Share of sales $_{i, S I C 4}$. Here, Cold War shock $i$ is the instrument for firm $i$. $\Delta$ Contracts $_{S I C 4}$ is the difference between the average contracts awarded to the focal industry in the pre- (1986-1988) and post- (1990-1992) periods. Share of sales $_{i, S I C 4}$ is the share of firm $i$ 's sales during 1982-1985 in the focal industry, calculated using the Compustat Segments dataset. ${ }^{75}$ We use a multi-year lag in calculating shares of sales to alleviate concerns that firms might have anticipated the end of the Cold War. Under that scenario, firms might have entered industries where they anticipated growing procurement and exited industries where they anticipated shrinking procurement.

Figure D1 presents the timeline used for estimating the Cold War shock instrumental variable. Figure D2 and Table D8 present comparisons of procurement contracts awarded to various industries in 1988 and 1992.

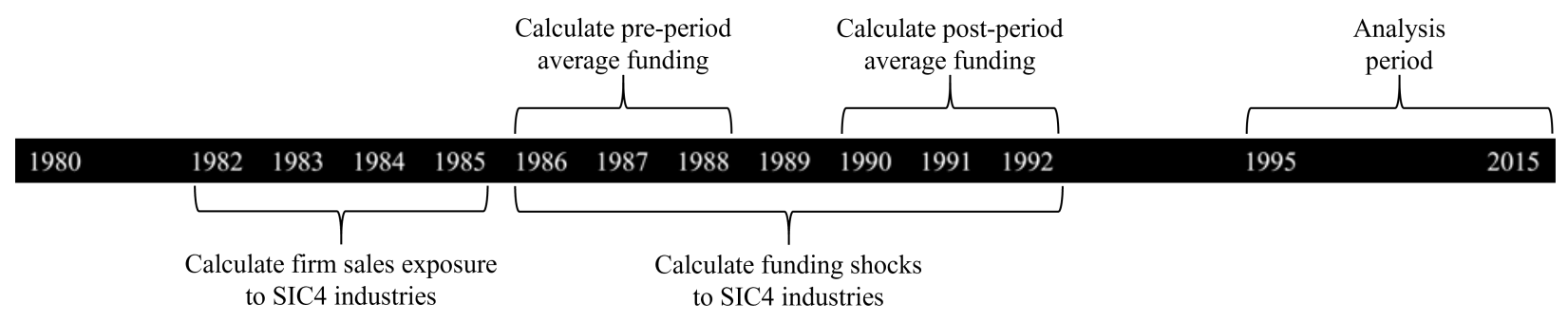

Figure D1: The Cold War Identification Strategy Timeline

This figure presents the timeline used for estimating the Cold War shock instrumental variable.

\footnotetext{
${ }^{75}$ For example, Komatsu Ltd. operated only in Construction Machinery and Equipment (SIC 3531) during 19821985, generating $100 \%$ of its sales in that industry. As a result, its Cold War shock came entirely from reallocations in contracts awarded to SIC 3531. Caterpillar Inc. generated $76 \%$ of its sales during 1982-1985 in Construction Machinery and Equipment (SIC 3531), and 24\% in Internal Combustion Engines, Not Elsewhere Classified (SIC 2519). As a result, $76 \%$ of this firm's Cold War shock came from reallocations in contracts awarded to SIC 3531, and $24 \%$ from reallocations to SIC 2519.
} 


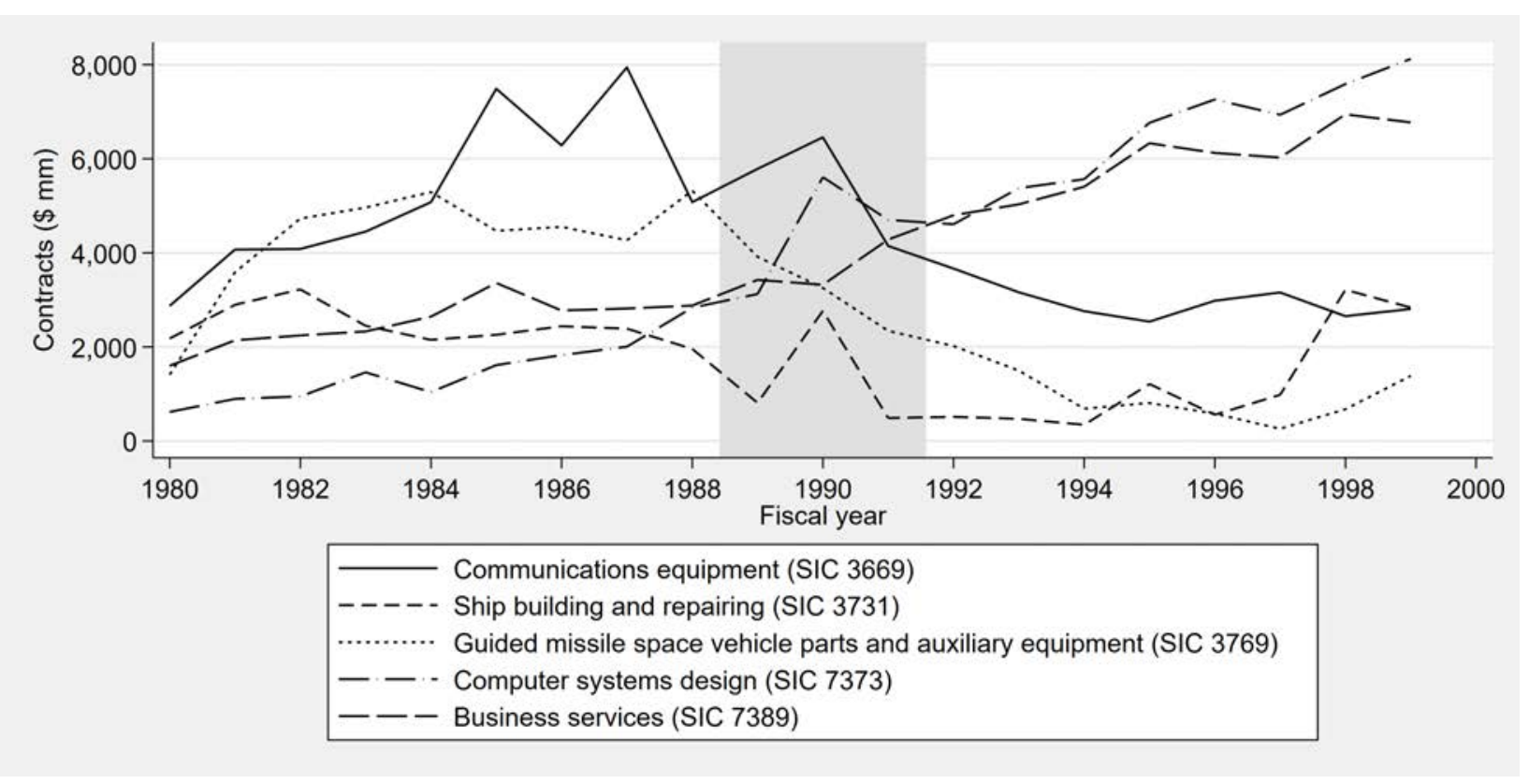

Figure D2: Procurement During and After the Cold War

This figure plots the aggregate value of procurement contracts awarded by federal agencies to various industries. Dollar values are adjusted using the GDP Implicit Price Deflator to reflect constant 2012 dollars (U.S. Bureau of Economic Analysis, 2021).

Table D8: Procurement By SIC4 Industry Around the End of the Cold War

\begin{tabular}{lllll}
\hline Rank & SIC4 & $\begin{array}{l}1988 \text { Contracts } \\
(\$ \mathrm{~mm})\end{array}$ & $\begin{array}{l}1992 \text { Contracts } \\
(\$ \mathrm{~mm})\end{array}$ & \begin{tabular}{l} 
Industry description \\
\hline 1
\end{tabular} \\
\hline 2389 & 2,881 & 4,799 & $\begin{array}{l}\text { Business Services, Not Elsewhere Classified } \\
\text { Computer Integrated Systems Design }\end{array}$ \\
3 & 7373 & 2,836 & 4,608 & Space Research and Technology \\
4 & 9661 & 233 & 1,731 & Cigarettes \\
5 & 4813 & 191 & 1,436 & Telephone Communications, Except Radiotelephone \\
6 & 3523 & 1,157 & 1,381 & Farm Machinery and Equipment \\
7 & 4812 & 2,055 & 2,100 & Radiotelephone Communications \\
8 & 2833 & 1,096 & 1,774 & Medicinal Chemicals and Botanical Products \\
9 & 0131 & 2 & 560 & Cotton \\
10 & 5047 & 218 & 754 & Medical, Dental, and Hospital Equipment and Supplies \\
$\ldots$ & $\ldots$ & $\ldots$ & $\ldots$ & . \\
765 & 3711 & 3,446 & 2,195 & Motor Vehicles and Passenger Car Bodies \\
766 & 3669 & 5,079 & 3,668 & Communications Equipment, Not Elsewhere Classified \\
767 & 3731 & 1,960 & 516 & Ship Building and Repairing \\
768 & 1311 & 6,044 & 4,177 & Crude Petroleum and Natural Gas \\
769 & 6794 & 2,063 & 185 & Patent Owners and Lessors \\
770 & 3841 & 3,086 & 1,055 & Surgical and Medical Instruments and Apparatus \\
771 & 3769 & 5,324 & 2,020 & Guided Missile Space Vehicle Parts and Auxiliary Equipment, Not \\
& & & & Elsewhere Classified \\
772 & 3442 & 5,028 & 1,671 & Metal Doors, Sash, Frames, Molding, and Trim Manufacturing \\
773 & 3812 & 7,986 & 3,326 & Search, Detection, Navigation, Guidance, Aeronautical, and Nauti- \\
& & & 39,074 & cal Systems and Instruments \\
774 & 3721 & 65,698 & Aircraft \\
\hline
\end{tabular}

Notes: This table displays the procurement contracts (in constant 2012 dollars) awarded by all federal agencies in 1988 and 1992 to each SIC4 industry. Observations are sorted in descending order of the difference between 1992 and 1988. 


\section{D.3 First Stage Results}

Table D9 shows the first stage results of the two-stage least squares (2SLS) instrumental variable estimations reported in this paper.

Table D9: Instrumental Variable Estimation (First Stage)

\begin{tabular}{|c|c|c|c|c|}
\hline & (1) & $(2)$ & $(3)$ & $(4)$ \\
\hline & \multicolumn{4}{|c|}{$\ln (\mathrm{R} \& \mathrm{D} \text { contracts })_{t-3}$} \\
\hline & $\begin{array}{l}\text { Industry } \\
\text { R\&D } \\
\text { funding }\end{array}$ & $\begin{array}{l}\text { Agency } \\
\text { R\&D } \\
\text { budget }\end{array}$ & $\begin{array}{c}\text { Windfall- } \\
\text { predicted } \\
\text { R\&D budget }\end{array}$ & $\begin{array}{c}\text { PSC } \\
\text { R\&D } \\
\text { funding }\end{array}$ \\
\hline $\ln (\text { Industry R\&D funding })_{t-3}$ & $\begin{array}{c}0.072 \\
(0.007)\end{array}$ & & & \\
\hline $\ln (\text { Agency R\&D budget })_{t-3}$ & & $\begin{array}{c}0.072 \\
(0.007)\end{array}$ & & \\
\hline $\ln (\text { Windfall-predicted R\&D budget })_{t-3}$ & & & $\begin{array}{c}0.071 \\
(0.007)\end{array}$ & \\
\hline $\ln (\text { PSC R\&D funding })_{t-3}$ & & & & $\begin{array}{c}0.321 \\
(0.118)\end{array}$ \\
\hline $\ln (\mathrm{R} \& \mathrm{D} \text { stock })_{t-3}$ & $\begin{array}{c}0.041 \\
(0.030)\end{array}$ & $\begin{array}{c}0.041 \\
(0.031)\end{array}$ & $\begin{array}{c}0.042 \\
(0.031)\end{array}$ & $\begin{array}{c}0.164 \\
(0.041)\end{array}$ \\
\hline Sample years & $1980-2015$ & $1980-2015$ & $1980-2015$ & $1980-2015$ \\
\hline Firm fixed effects & Yes & Yes & Yes & Yes \\
\hline Year fixed effects & Yes & Yes & Yes & Yes \\
\hline Observations & 41,047 & 41,086 & 41,100 & 43,895 \\
\hline F statistic & 51 & 53 & 53 & 12 \\
\hline Adjusted R-squared & 0.703 & 0.703 & 0.705 & 0.675 \\
\hline
\end{tabular}

Notes: This table displays first stage OLS regression results. Standard errors (in parentheses) are clustered at the firm level. 


\section{Appendix E Agency Variation}

Federal agencies are heterogeneous in the size and composition of their procurement contracts (Table E10), their propensity to offer noncompetitive downstream procurement contracts (Figure E3), as well as the characteristics of their contractors (Table E11). Tables E12 and E13 further show that the dollar values of R\&D contracts from DoD, NASA, and DoT are positively correlated (p-value $<$ 0.001). Defense R\&D contractors tend to also work for NASA, as shown in Table E14. In general, if a firm is an R\&D contractor for a non-DoD agency, it is also a DoD R\&D contractor.

Table E10: Contract Descriptive Statistics by Awarding Agency

\begin{tabular}{|c|c|c|c|c|c|c|}
\hline & \multirow[t]{2}{*}{$(1)$} & \multirow[t]{2}{*}{$(2)$} & \multirow[t]{2}{*}{$(3)$} & \multirow{2}{*}{\multicolumn{3}{|c|}{$\begin{array}{l}(4) \quad(5) \quad(6) \\
\text { Distribution }\end{array}$}} \\
\hline & & & & & & \\
\hline & No. of contracts & Mean & Std. dev. & 10 th & 50 th & 90 th \\
\hline \multicolumn{7}{|l|}{ DoD } \\
\hline All contracts $(\$ \mathrm{~mm})$ & $4,360,407$ & 1.1 & 56.3 & 0.0 & 0.0 & 0.5 \\
\hline R\&D contracts $(\$ \mathrm{~mm})$ & 152,334 & 4.8 & 134.8 & 0.1 & 0.3 & 4.2 \\
\hline Non-R\&D contracts $(\$ \mathrm{~mm})$ & $4,030,148$ & 1.0 & 52.2 & 0.0 & 0.0 & 0.4 \\
\hline Noncompetitive downstream contracts $(\$ \mathrm{~mm})$ & $1,255,908$ & 2.0 & 78.7 & 0.0 & 0.1 & 0.9 \\
\hline \multicolumn{7}{|l|}{ NASA } \\
\hline All contracts $(\$ \mathrm{~mm})$ & 75,288 & 3.9 & 143.1 & 0.0 & 0.1 & 1.2 \\
\hline R\&D contracts $(\$ \mathrm{~mm})$ & 19,064 & 7.3 & 193.3 & 0.0 & 0.3 & 3.9 \\
\hline Non-R\&D contracts $(\$ \mathrm{~mm})$ & 49,477 & 3.2 & 129.4 & 0.0 & 0.1 & 0.7 \\
\hline Noncompetitive downstream contracts $(\$ \mathrm{~mm})$ & 14,736 & 5.3 & 218.3 & 0.0 & 0.0 & 0.5 \\
\hline \multicolumn{7}{|l|}{ DoT } \\
\hline All contracts $(\$ \mathrm{~mm})$ & 25,116 & 1.6 & 26.7 & 0.0 & 0.1 & 1.1 \\
\hline R\&D contracts $(\$ \mathrm{~mm})$ & 1,983 & 3.9 & 62.6 & 0.0 & 0.2 & 1.6 \\
\hline Non-R\&D contracts $(\$ \mathrm{~mm})$ & 21,838 & 1.5 & 21.6 & 0.0 & 0.1 & 1.1 \\
\hline Noncompetitive downstream contracts $(\$ \mathrm{~mm})$ & 6,704 & 0.8 & 7.0 & 0.0 & 0.1 & 0.7 \\
\hline \multicolumn{7}{|l|}{ HHS } \\
\hline All contracts $(\$ \mathrm{~mm})$ & 112,828 & 0.8 & 23.7 & 0.0 & 0.0 & 0.2 \\
\hline R\&D contracts $(\$ \mathrm{~mm})$ & 2,971 & 2.3 & 12.7 & 0.0 & 0.1 & 2.6 \\
\hline Non-R\&D contracts $(\$ \mathrm{~mm})$ & 104,998 & 0.8 & 24.5 & 0.0 & 0.0 & 0.2 \\
\hline Noncompetitive downstream contracts $(\$ \mathrm{~mm})$ & 32,494 & 0.3 & 11.8 & 0.0 & 0.0 & 0.1 \\
\hline \multicolumn{7}{|l|}{ DoE } \\
\hline All contracts $(\$ \mathrm{~mm})$ & 16,950 & 18.8 & 883.1 & 0.0 & 0.0 & 1.2 \\
\hline R\&D contracts $(\$ \mathrm{~mm})$ & 1,853 & 3.0 & 15.5 & 0.0 & 0.4 & 4.3 \\
\hline Non-R\&D contracts $(\$ \mathrm{~mm})$ & 13,552 & 23.3 & 987.5 & 0.0 & 0.0 & 1.1 \\
\hline Noncompetitive downstream contracts $(\$ \mathrm{~mm})$ & 3,219 & 23.7 & 389.2 & 0.0 & 0.0 & 2.0 \\
\hline \multicolumn{7}{|l|}{ DHS } \\
\hline All contracts $(\$ \mathrm{~mm})$ & 56,828 & 0.9 & 20.4 & 0.0 & 0.0 & 0.4 \\
\hline R\&D contracts $(\$ \mathrm{~mm})$ & 814 & 3.2 & 30.6 & 0.0 & 0.1 & 3.0 \\
\hline Non-R\&D contracts $(\$ \mathrm{~mm})$ & 53,291 & 0.9 & 20.7 & 0.0 & 0.0 & 0.5 \\
\hline Noncompetitive downstream contracts $(\$ \mathrm{~mm})$ & 19,561 & 0.7 & 26.8 & 0.0 & 0.0 & 0.4 \\
\hline \multicolumn{7}{|l|}{$\mathrm{DoC}$} \\
\hline All contracts $(\$ \mathrm{~mm})$ & 40,189 & 0.4 & 9.3 & 0.0 & 0.0 & 0.3 \\
\hline $\mathrm{R} \& \mathrm{D}$ contracts $(\$ \mathrm{~mm})$ & 386 & 3.4 & 49.7 & 0.0 & 0.1 & 1.2 \\
\hline Non-R\&D contracts $(\$ \mathrm{~mm})$ & 37,845 & 0.4 & 8.1 & 0.0 & 0.0 & 0.3 \\
\hline Noncompetitive downstream contracts $(\$ \mathrm{~mm})$ & 9,781 & 0.1 & 1.0 & 0.0 & 0.0 & 0.2 \\
\hline \multicolumn{7}{|l|}{ Other } \\
\hline All contracts $(\$ \mathrm{~mm})$ & $4,264,685$ & 0.3 & 59.2 & 0.0 & 0.0 & 0.1 \\
\hline R\&D contracts $(\$ \mathrm{~mm})$ & 34,483 & 4.9 & 144.8 & 0.0 & 0.2 & 2.9 \\
\hline Non-R\&D contracts $(\$ \mathrm{~mm})$ & $3,987,521$ & 0.3 & 59.7 & 0.0 & 0.0 & 0.1 \\
\hline Noncompetitive downstream contracts $(\$ \mathrm{~mm})$ & 897,730 & 0.3 & 37.2 & 0.0 & 0.0 & 0.0 \\
\hline
\end{tabular}

Notes: This table displays contract-level descriptive statistics over the sample period of 1980-2015 by awarding agency. The unit of analysis is a contract. 


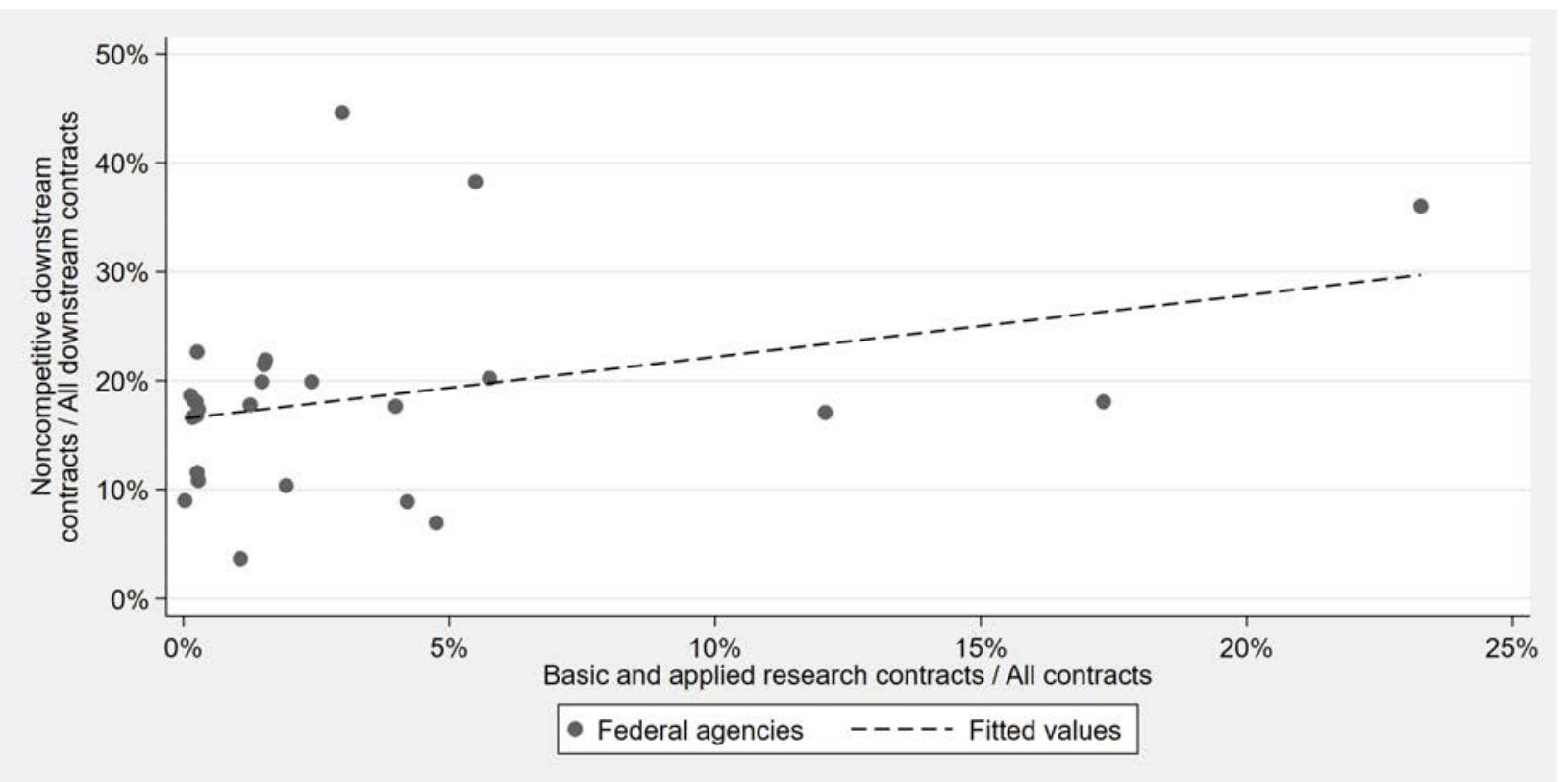

Figure E3: Upstream R\&D and Noncompetitive Downstream Procurement

This figure presents the relationship between upstream $R \& D$ and noncompetitive downstream procurement at the level of agencies that awarded $\$ 100+$ million in R\&D contracts during 1980-2020.

Table E11: R\&D Contractor Descriptive Statistics by Awarding Agency

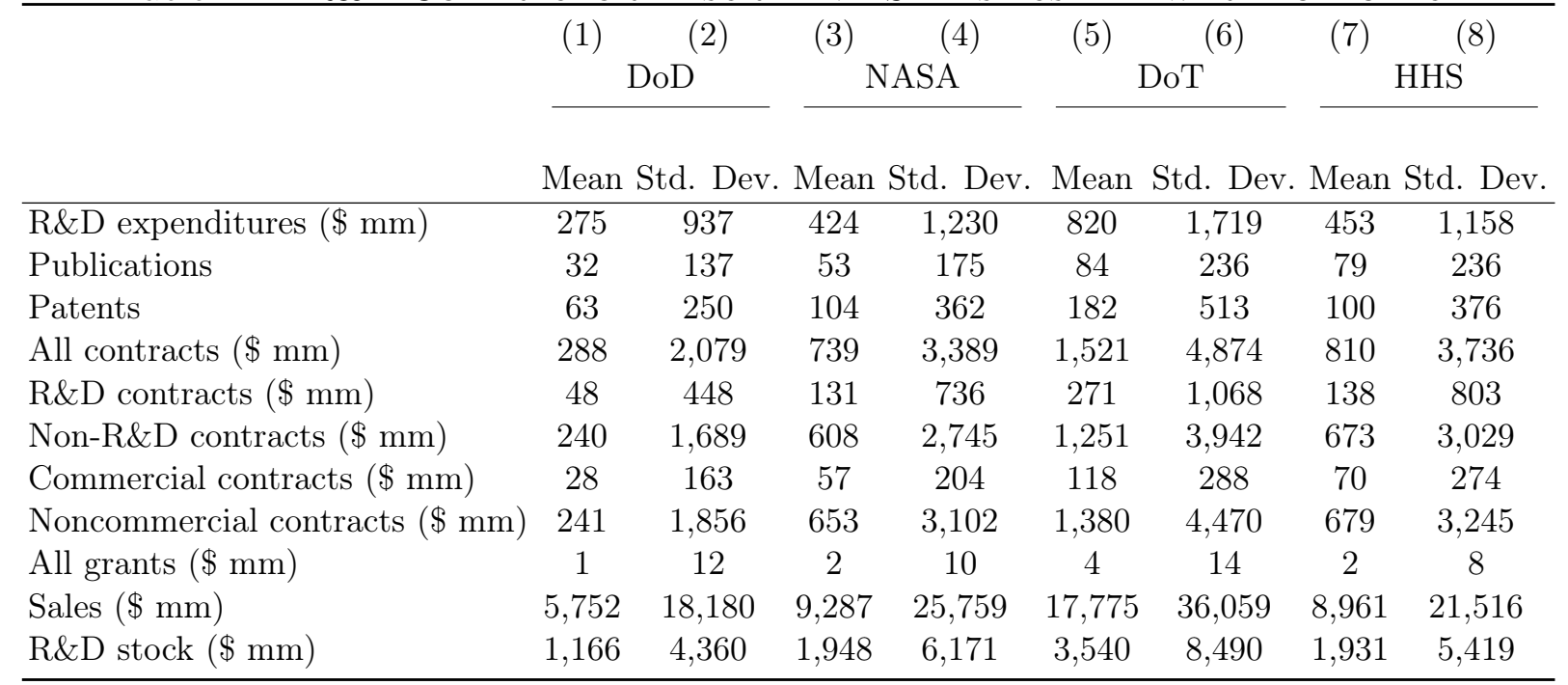

Notes: This table displays contractor descriptive statistics over the sample period of 1980-2015 by awarding agency. The unit of analysis is a firm-year. Statistics are only provided for R\&D contractors. Grants and commercial contracts are only summarized for years 2001-2015 and 1994-2015, respectively. 
Table E11: R\&D Contractor Descriptive Statistics By Awarding Agency (CONTINUED)

\begin{tabular}{|c|c|c|c|c|c|c|c|c|}
\hline & (9) & $(10)$ & $(11)$ & $(12)$ & $(13)$ & $(14)$ & $(15)$ & $(16)$ \\
\hline & \multicolumn{2}{|c|}{ DoE } & \multicolumn{2}{|c|}{ DHS } & \multicolumn{2}{|c|}{$\mathrm{DoC}$} & \multicolumn{2}{|c|}{ Other } \\
\hline & Mean & Std. Dev. & Mean & Std. Dev. & Mean & Std. Dev. & Mean & Std. Dev. \\
\hline R\&D expenditures $(\$ \mathrm{~mm})$ & 651 & 1,571 & 746 & 1,624 & 643 & 1,244 & 451 & 1,252 \\
\hline Publications & 73 & 184 & 82 & 242 & 104 & 275 & 54 & 183 \\
\hline Patents & 120 & 247 & 188 & 532 & 193 & 553 & 98 & 320 \\
\hline All contracts $(\$ \mathrm{~mm})$ & 1,513 & 4,948 & 1,522 & 5,016 & 1,800 & 5,551 & 508 & 2,789 \\
\hline $\mathrm{R} \& \mathrm{D}$ contracts $(\$ \mathrm{~mm})$ & 280 & 1,090 & 254 & 1,087 & 316 & 1,201 & 85 & 601 \\
\hline Non-R\&D contracts $(\$ \mathrm{~mm})$ & 1,232 & 3,994 & 1,268 & 4,061 & 1,485 & 4,504 & 423 & 2,264 \\
\hline Commercial contracts $(\$ \mathrm{~mm})$ & 114 & 304 & 130 & 355 & 126 & 314 & 53 & 224 \\
\hline Noncommercial contracts $(\$ \mathrm{~mm})$ & 1,500 & 4,764 & 1,315 & 4,391 & 1,560 & 4,983 & 429 & 2,493 \\
\hline All grants $(\$ \mathrm{~mm})$ & 6 & 32 & 3 & 13 & 4 & 13 & 2 & 15 \\
\hline Sales $(\$ \mathrm{~mm})$ & 16,517 & 34,577 & 18,647 & 37,209 & 13,362 & 24,678 & 10,870 & 30,029 \\
\hline R\&D stock $(\$ \mathrm{~mm})$ & 2,975 & 7,967 & 3,198 & 7,869 & 2,853 & 6,021 & 1,904 & 5,890 \\
\hline
\end{tabular}

Notes: This table displays contractor descriptive statistics over the sample period of 1980-2015 by awarding agency. The unit of analysis is a firm-year. Statistics are only provided for R\&D contractors. Grants and commercial contracts are only summarized for years 2001-2015 and 1994-2015, respectively.

Table E12: Correlations

$(1)$

$(2)$

$(3)$

(4)

(5)

$(6)$

(7)

(8)

(1) DoD R\&D contracts 1.00

(2) NASA R\&D contracts $0.27^{* * *} \quad 1.00$

(3) DoT R\&D contracts

(4) HHS R\&D contracts

(5) DoE R\&D contracts

(6) DHS R\&D contracts

(7) DoC R\&D contracts

$0.53^{* * *} \quad 0.20^{* * *}$

$0.07^{* * *} \quad 0.01^{* *}$

$0.30^{* * *} \quad 0.12^{* * *}$

$0.14^{* * *} \quad 0.05^{* * *}$

$0.29^{* * *} \quad 0.12^{* * *}$

1.00

$0.02^{* * *}$

$0.13^{* * *}$

$0.02^{* * *}$

$0.49^{* * *}$

1.00

$0.01^{* *}$

0.00

0.01

1.00

$0.01 \quad 1.00$

(8) Other R\&D contracts $\quad 0.15^{* * *} \quad 0.11^{* * *} \quad 0.07^{* * *} \quad 0.02^{* * *} \quad 0.08^{* * *} \quad 0.01^{* *} \quad 0.01^{* * *} \quad 1.00$

(8) Other R\&D contracts $\quad 0.15^{* * *} \quad 0.11^{* * *} \quad 0.07^{* * *} \quad 0.02^{* * *} \quad 0.08^{* * *} \quad 0.01^{* *} \quad 0.01^{* * *} \quad 1.00$

$0.11^{* * *} \quad 0.01$

$\quad 1.00$

Notes: This table displays pairwise Pearson correlations for R\&D contracts received from various agencies. $* \mathrm{p}<$ $0.05^{* *} \mathrm{p}<0.01^{* * *} \mathrm{p}<0.001$ 
Table E13: Correlations Using Normalized R\&D Contracts

(1)

$(2)$

(3)

(4)

$(5)$

(6)

(7)

(8)

(1) DoD R\&D contracts $\quad 1.00$

(2) NASA R\&D contracts $0.08^{* * *} \quad 1.00$

(3) DoT R\&D contracts $0.03^{* * *} \quad 0.05^{* * *} \quad 1.00$

$\begin{array}{lllll}\text { (4) HHS R\&D contracts } & 0.00 & -0.00 & -0.00 & 1.00\end{array}$

$\begin{array}{llllll}\text { (5) DoE R\&D contracts } & 0.00 & 0.03^{* * *} & 0.00 & -0.00 & 1.00\end{array}$

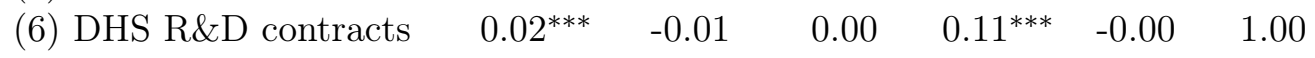

$\begin{array}{llllllll}\text { (7) DoC R\&D contracts } & 0.01^{*} & 0.19^{* * *} & 0.00 & -0.00 & 0.00 & -0.00 & 1.00\end{array}$

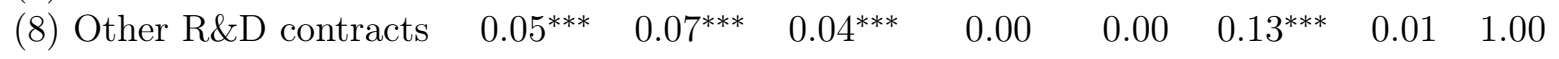

Notes: This table displays pairwise correlations for $\mathrm{R} \& \mathrm{D}$ contracts received from various agencies. To avoid spurious correlations due to firm size, R\&D contract values have been normalized by sales. ${ }^{*} \mathrm{p}<0.05 * * \mathrm{p}<0.01 * * * \mathrm{p}<$ 0.001

Table E14: R\&D CONTRACTORS By Awarding Agency

\begin{tabular}{|c|c|c|c|c|c|c|c|c|c|}
\hline $\begin{array}{l}\text { Awarding } \\
\text { agency }\end{array}$ & $\begin{array}{c}\mathrm{R} \& \mathrm{D} \\
\text { contractors }\end{array}$ & (1) & (2) & (3) & (4) & (5) & (6) & (7) & (8) \\
\hline (1) DoD & 781 & $781(100 \%)$ & $218(28 \%)$ & $93(12 \%)$ & $108(14 \%)$ & $80(10 \%)$ & $80(10 \%)$ & $67(9 \%)$ & $249(32 \%)$ \\
\hline (2) NASA & 248 & 218 & $248(100 \%)$ & $65(26 \%)$ & $55(22 \%)$ & $59(24 \%)$ & $52(21 \%)$ & $45(18 \%)$ & $119(48 \%)$ \\
\hline (3) DoT & 101 & $93(92 \%)$ & $65(64 \%)$ & $101(100 \%)$ & $36(36 \%)$ & $38(38 \%)$ & $39(39 \%)$ & $31(31 \%)$ & $69(68 \%)$ \\
\hline (4) HHS & 207 & $108(52 \%)$ & $55(27 \%)$ & $36(17 \%)$ & $207(100 \%)$ & $31(15 \%)$ & $47(23 \%)$ & $34(16 \%)$ & $113(55 \%)$ \\
\hline (5) DoE & 95 & $80(84 \%)$ & $59(62 \%)$ & $38(40 \%)$ & $31(33 \%)$ & $95(100 \%)$ & $25(26 \%)$ & $25(26 \%)$ & $67(71 \%)$ \\
\hline (6) DHS & 92 & $80(87 \%)$ & $52(57 \%)$ & $39(42 \%)$ & $47(51 \%)$ & $25(27 \%)$ & $92(100 \%)$ & $26(28 \%)$ & $67(73 \%)$ \\
\hline (7) DoC & 72 & $67(93 \%)$ & $45(63 \%)$ & $31(43 \%)$ & $34(47 \%)$ & $25(35 \%)$ & $26(36 \%)$ & $72(100 \%)$ & $55(76 \%)$ \\
\hline (8) Other & 372 & $249(67 \%)$ & $119(32 \%)$ & $69(19 \%)$ & $113(30 \%)$ & $67(18 \%)$ & $67(18 \%)$ & $55(15 \%)$ & $372(100 \%)$ \\
\hline
\end{tabular}

Notes: This table displays frequency counts and percentages of R\&D contractors by awarding agency. 


\section{Appendix F Industry Variation}

Our sample is drawn from a wide distribution of industries (Table F15). The classification scheme used to group sample firms into several main industries is presented in Table F16. Table F17 presents descriptive statistics by main industry, while Table F18 presents mean comparison tests between $R \& D$ contractors other firms within the same main industry.

Table F15: Distribution OF FiRMs BY SIC2 InDUSTRY

\begin{tabular}{llllll}
\hline SIC2 code & Number of firms & SIC2 code & Number of firms & SIC2 code & Number of firms \\
\hline 28 & 796 & 32 & 29 & 14 & 5 \\
36 & 680 & 49 & 27 & 21 & 5 \\
38 & 672 & 22 & 26 & 60 & 4 \\
73 & 567 & 27 & 23 & 63 & 4 \\
35 & 540 & 51 & 21 & 10 & 3 \\
37 & 145 & 29 & 21 & 75 & 3 \\
34 & 101 & 59 & 15 & 12 & 3 \\
30 & 79 & 01 & 14 & 76 & 3 \\
87 & 70 & 65 & 13 & 61 & 3 \\
48 & 67 & 79 & 13 & 42 & 2 \\
20 & 64 & 23 & 10 & 45 & 2 \\
39 & 60 & 24 & 9 & 54 & 2 \\
99 & 59 & 17 & 8 & 72 & 2 \\
33 & 58 & 16 & 8 & 47 & 2 \\
26 & 50 & 78 & 8 & 07 & 2 \\
67 & 46 & 31 & 7 & 64 & 2 \\
13 & 46 & 62 & 6 & 44 & 1 \\
50 & 34 & 82 & 6 & 02 & 1 \\
25 & 31 & 15 & 6 & 70 & 1 \\
80 & 30 & 58 & 5 & & \\
\hline
\end{tabular}

Notes: This table displays the distribution of sample firms by two-digit SIC code. 
Table F16: Classification Into Main Industries

\begin{tabular}{|c|c|c|}
\hline Main industry & $\begin{array}{l}\text { SIC2 } \\
\text { code }\end{array}$ & Description \\
\hline Chemicals & 28 & $\begin{array}{l}\text { Firms producing basic chemicals (including acids, alkalies, salts, and organic } \\
\text { chemicals), chemical products used in manufacturing (including synthetic fibers, } \\
\text { plastics materials, dry colors, and pigments), or finished chemical products used } \\
\text { for ultimate consumption (including drugs, cosmetics, and soaps) or as supplies } \\
\text { in other industries (including paints, fertilizers, and explosives). }\end{array}$ \\
\hline Electronics & 35,36 & $\begin{array}{l}\text { Firms manufacturing industrial and commercial machinery, equipment, and } \\
\text { computers (including engines and turbines; farm and garden machinery; con- } \\
\text { struction, mining, and oil field machinery; elevators and conveying equipment; } \\
\text { hoists, cranes, monorails, and industrial trucks and tractors; metalworking ma- } \\
\text { chinery; special industry machinery; general industrial machinery; computer and } \\
\text { peripheral equipment and office machinery; and refrigeration and service indus- } \\
\text { try machinery), or machinery, apparatus, and supplies for the generation, stor- } \\
\text { age, transmission, transformation, and utilization of electrical energy (including } \\
\text { electricity distribution equipment; electrical industrial apparatus; household ap- } \\
\text { pliances; electrical lighting and wiring equipment; radio and television receiving } \\
\text { equipment; communications equipment; electronic components and accessories; } \\
\text { and other electrical equipment and supplies). }\end{array}$ \\
\hline Instruments & 38 & $\begin{array}{l}\text { Firms manufacturing instruments (including professional and scientific) for mea- } \\
\text { suring, testing, analyzing, and controlling, and their associated sensors and ac- } \\
\text { cessories; optical instruments and lenses; surveying and drafting instruments; } \\
\text { hydrological, hydrographic, meteorological, and geophysical equipment; search, } \\
\text { detection, navigation, and guidance systems and equipment; surgical, medical, } \\
\text { and dental instruments, equipment, and supplies; ophthalmic goods; photo- } \\
\text { graphic equipment and supplies; or watches and clocks. }\end{array}$ \\
\hline Business services & 73,87 & $\begin{array}{l}\text { Firms providing business services (including advertising, credit reporting, collec- } \\
\text { tion of claims, mailing, reproduction, stenographic, news syndicates, computer } \\
\text { programming, photocopying, duplicating, data processing, services to buildings, } \\
\text { and help supply services), or engineering, accounting, research, management, } \\
\text { and related services (including engineering, architectural, and surveying ser- } \\
\text { vices; accounting, auditing, and bookkeeping services; research, development, } \\
\text { and testing services; and management and public relations services). }\end{array}$ \\
\hline
\end{tabular}

Notes: This table displays the classification scheme used to group sample firms into several main industries. Industries not specifically listed were classified as "Others." 
Table F17: Descriptive Statistics By Main Industry

\begin{tabular}{|c|c|c|c|c|c|c|c|c|c|c|}
\hline & $(1)$ & $(2)$ & $(3)$ & $(4)$ & $(5)$ & $(6)$ & $(7)$ & $(8)$ & $(9)$ & $(10)$ \\
\hline & \multicolumn{2}{|c|}{ Chemicals } & \multicolumn{2}{|c|}{ Electronics } & \multicolumn{2}{|c|}{ Instruments } & \multicolumn{2}{|c|}{ Business services } & \multicolumn{2}{|c|}{ Others } \\
\hline & Mean & Std. Dev. & Mean & Std. Dev. & Mean & Std. Dev. & Mean & Std. Dev. & Mean & Std. Dev. \\
\hline R\&D expenditures $(\$ \mathrm{~mm})$ & 269 & 912 & 120 & 496 & 47 & 140 & 203 & 899 & 167 & 757 \\
\hline Renowned scientists & 16 & 71 & 3 & 18 & 2 & 9 & 6 & 47 & 6 & 28 \\
\hline Publications & 55 & 172 & 9 & 44 & 7 & 26 & 22 & 169 & 15 & 85 \\
\hline Patents & 31 & 84 & 35 & 148 & 13 & 47 & 43 & 344 & 30 & 116 \\
\hline All contracts $(\$ \mathrm{~mm})$ & 14 & 111 & 22 & 202 & 126 & 1,135 & 31 & 209 & 273 & 2,204 \\
\hline $\mathrm{R} \& \mathrm{D}$ contracts $(\$ \mathrm{~mm})$ & 1 & 7 & 4 & 72 & 22 & 239 & 3 & 25 & 45 & 473 \\
\hline Non-R\&D contracts $(\$ \mathrm{~mm})$ & 13 & 109 & 19 & 154 & 104 & 917 & 28 & 190 & 228 & 1,792 \\
\hline Commercial contracts $(\$ \mathrm{~mm})$ & 9 & 98 & 5 & 60 & 11 & 83 & 7 & 50 & 27 & 169 \\
\hline Noncommercial contracts $(\$ \mathrm{~mm})$ & 5 & 47 & 11 & 92 & 118 & 1,031 & 20 & 147 & 254 & 2,093 \\
\hline All grants $(\$ \mathrm{~mm})$ & 1 & 16 & 0 & 4 & 0 & 2 & 0 & 1 & 1 & 18 \\
\hline Sales $(\$ \mathrm{~mm})$ & 3,313 & 8,828 & 1,805 & 7,064 & 813 & 2,746 & 1,966 & 9,862 & 8,044 & 25,601 \\
\hline R\&D stock $(\$ \mathrm{~mm})$ & 1,110 & 4,120 & 497 & 2,193 & 191 & 550 & 753 & 3,877 & 626 & 3,467 \\
\hline
\end{tabular}

Notes: This table displays descriptive statistics over the sample period of 1980-2015 by main industry. The unit of analysis is a firm-year. Statistics are only provided for contractors. Grants and commercial contracts are only summarized for years 2001-2015 and 1995-2015, respectively.

Table F18: R\&D CONTRACTORS Vs. Other Firms BY MAIN Industry

\begin{tabular}{|c|c|c|c|c|c|c|c|c|c|c|}
\hline & \multirow{2}{*}{\multicolumn{2}{|c|}{$\begin{array}{l}(1) \quad(2) \\
\text { Chemicals }\end{array}$}} & \multirow{2}{*}{\multicolumn{2}{|c|}{$\begin{array}{c}(3) \quad(4) \\
\text { Electronics }\end{array}$}} & \multirow{2}{*}{\multicolumn{2}{|c|}{$\begin{array}{c}(5) \quad(6) \\
\text { Instruments }\end{array}$}} & (7) & (8) & (9) & (10) \\
\hline & & & & & & & \multicolumn{2}{|c|}{ Business services } & \multicolumn{2}{|c|}{ Others } \\
\hline & Diff. & $\mathrm{t}$ & Diff. & $\mathrm{t}$ & Diff. & $\mathrm{t}$ & Diff. & $\mathrm{t}$ & Diff. & $\mathrm{t}$ \\
\hline $\mathrm{R} \& \mathrm{D}$ expenditures $(\$ \mathrm{~mm})$ & 356.593 & 24.84 & 173.648 & 24.6 & 71.097 & 26.3 & 323.871 & 15.7 & 301.350 & 26.3 \\
\hline Renowned scientists & 22.663 & 20.65 & 4.993 & 20.6 & 3.201 & 19.7 & 12.275 & 12.0 & 11.353 & 31.0 \\
\hline R\&D intensity (in $\$ \mathrm{~mm}$ ) & -21.067 & -2.86 & -0.357 & -1.9 & -0.012 & -0.0 & -3.063 & -1.4 & -0.453 & -2.0 \\
\hline Publications per $\$ 1 \mathrm{~mm}$ in $\mathrm{R} \& \mathrm{D}$ exp. & 0.181 & 1.63 & 0.348 & 5.1 & -0.012 & -0.1 & 0.091 & 0.4 & 0.111 & 2.6 \\
\hline Patents per $\$ 1 \mathrm{~mm}$ in $\mathrm{R} \& \mathrm{D}$ exp. & -0.086 & -0.47 & -1.089 & -0.8 & -0.489 & -3.3 & 0.014 & 0.2 & -1.012 & -4.1 \\
\hline All grants $(\$ \mathrm{~mm})$ & 1.009 & 3.11 & 0.569 & 6.3 & 0.432 & 7.8 & 0.192 & 5.3 & 1.409 & 3.7 \\
\hline
\end{tabular}

Notes: This table displays mean comparison tests between R\&D contractors and other firms within the same main industry. RED intensity is calculated as $\mathrm{R} \& \mathrm{D}$ expenditures divided by Sales. Grants are only summarized for years 2001-2015. The two-sample t-tests use unequal variances. 
Table F19 breaks the main results by industry. Columns 2 and 5 present 2SLS estimates using Industry RES funding and its interactions with industry indicator variables as instrumental variables for $R \& D$ contracts and its interactions with industry indicator variables. In Column 3 and 6 , we use Windfall-predicted R\&D budget as the key instrumental variable. The coefficient estimates in Columns 2-3 suggest that the causal effect of RED contracts on publications is present across all industries. Conversely, we do not find evidence in Columns 5-6 that $R \mathscr{E} D$ contracts drive patents across a variety of industries.

Table F19: VARIATION BY MAIn INDUSTRY

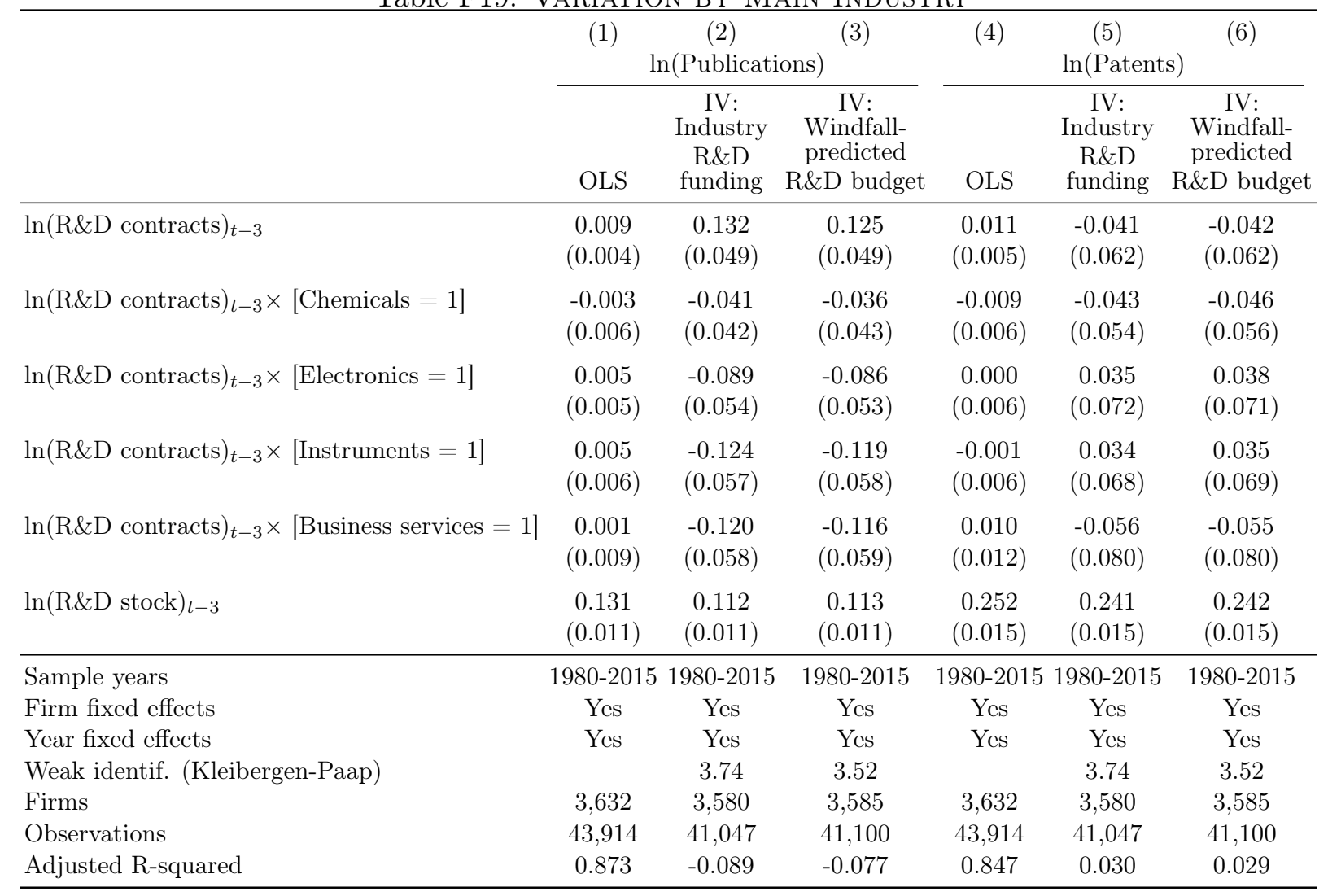

Notes: This table presents the estimation results for the relationship of R\&D contracts with publications and patents by main industry. The excluded industry indicator variable is Other. Standard errors (in parentheses) are clustered at the firm level. 


\section{Appendix G Robustness Checks}

\section{G.1 Other Measures of Publication Quality}

Table G20 reports results for the effect of R\&D contracts on corporate publications authored by renowned scientists from the AMWS directory (whether employed by the firm or not, Columns 1-2) and corporate publications cited by renowned scientists from the AMWS directory (whether authored by AMWS scientists or not, Columns 3-4).

Table G20: Other Measures of Publication Quality

\begin{tabular}{|c|c|c|c|c|}
\hline & \multicolumn{2}{|c|}{$\begin{array}{c}(1) \\
\ln (\text { Publications with AMWS collab. })\end{array}$} & \multicolumn{2}{|c|}{$\begin{array}{c}(3) \\
\ln (\text { Publications cited by AMWS })\end{array}$} \\
\hline & $\begin{array}{c}\text { IV: } \\
\text { Industry } \\
\text { R\&D } \\
\text { funding }\end{array}$ & $\begin{array}{c}\text { IV: } \\
\text { Windfall- } \\
\text { predicted } \\
\text { R\&D } \\
\text { budget }\end{array}$ & $\begin{array}{c}\text { IV: } \\
\text { Industry } \\
\text { R\&D } \\
\text { funding }\end{array}$ & $\begin{array}{c}\text { IV: } \\
\text { Windfall- } \\
\text { predicted } \\
\text { R\&D } \\
\text { budget }\end{array}$ \\
\hline $\ln (\mathrm{R} \& \mathrm{D} \text { contracts })_{t-3}$ & $\begin{array}{c}0.033 \\
(0.010)\end{array}$ & $\begin{array}{c}0.030 \\
(0.009)\end{array}$ & $\begin{array}{c}0.058 \\
(0.017)\end{array}$ & $\begin{array}{c}0.053 \\
(0.015)\end{array}$ \\
\hline $\ln (\mathrm{R} \& \mathrm{D} \text { stock })_{t-3}$ & $\begin{array}{c}0.029 \\
(0.007)\end{array}$ & $\begin{array}{c}0.029 \\
(0.007)\end{array}$ & $\begin{array}{c}0.050 \\
(0.010)\end{array}$ & $\begin{array}{c}0.050 \\
(0.010)\end{array}$ \\
\hline Sample years & $1980-2015$ & $1980-2015$ & $1980-2015$ & $1980-2015$ \\
\hline Firm fixed effects & Yes & Yes & Yes & Yes \\
\hline Year fixed effects & Yes & Yes & Yes & Yes \\
\hline Weak identif. (Kleibergen-Paap) & 101.13 & 105.37 & 101.13 & 105.37 \\
\hline Firms & 3,580 & 3,585 & 3,580 & 3,585 \\
\hline Observations & 41,047 & 41,100 & 41,047 & 41,100 \\
\hline Adjusted R-squared & -0.050 & -0.041 & -0.068 & -0.056 \\
\hline
\end{tabular}

Notes: This table presents 2SLS estimation results for the effect of R\&D contracts on high-quality corporate publications. RED contracts are instrumented using Industry RED funding or Windfall-predicted RED budget, as noted. Standard errors (in parentheses) are clustered at the firm level.

\section{G.2 Excluding Agencies}

One concern may be that our results could be driven by a single agency. For example, the DoD may impose secrecy requirements that could affect patenting behavior, as well as undermine our identification strategy that treats the end of the Cold War as an exogenous shock to sample firms. As shown in Tables G21, G22, and G23, our results are not driven solely by DoD R\&D contracts. The coefficient estimates on Non-DoD RED contracts are significantly larger in both the R\&D expenditures equation and the publications equation. Our results are also robust to excluding each of the other main agencies. 


\section{Table G21: R\&D Expenditures Equation Excluding Agencies}

\begin{tabular}{|c|c|c|c|c|c|c|c|c|c|}
\hline & (1) & $(2)$ & $(3)$ & (4) & $(5)$ & $(6)$ & (7) & (8) & $(9)$ \\
\hline & \multicolumn{9}{|c|}{$\ln (\mathrm{R} \& \mathrm{D}$ expenditures $)$} \\
\hline & $\begin{array}{c}\text { Top } 7 \\
\text { Agencies }\end{array}$ & $\begin{array}{c}\text { Other } \\
\text { Agencies }\end{array}$ & $\begin{array}{l}\text { Excl. } \\
\text { DoD }\end{array}$ & $\begin{array}{l}\text { Excl. } \\
\text { NASA }\end{array}$ & $\begin{array}{l}\text { Excl. } \\
\text { DoT }\end{array}$ & $\begin{array}{l}\text { Excl. } \\
\text { HHS }\end{array}$ & $\begin{array}{l}\text { Excl. } \\
\text { DoE }\end{array}$ & $\begin{array}{l}\text { Excl. } \\
\text { DHS }\end{array}$ & $\begin{array}{l}\text { Excl. } \\
\text { DoC }\end{array}$ \\
\hline $\ln$ (Top 7 R\&D contracts $)_{t-1}$ & $\begin{array}{c}0.062 \\
(0.024)\end{array}$ & & & & & & & & \\
\hline $\ln (\text { Other R\&D contracts })_{t-1}$ & & $\begin{array}{c}0.430 \\
(0.174)\end{array}$ & & & & & & & \\
\hline $\ln (\text { Non-DoD R\&D contracts })_{t-1}$ & & & $\begin{array}{c}0.193 \\
(0.080)\end{array}$ & & & & & & \\
\hline $\ln (\text { Non-NASA R\&D contracts })_{t-1}$ & & & & $\begin{array}{c}0.061 \\
(0.023)\end{array}$ & & & & & \\
\hline $\ln (\text { Non-DoT R\&D contracts })_{t-1}$ & & & & & $\begin{array}{c}0.060 \\
(0.023)\end{array}$ & & & & \\
\hline $\ln (\text { Non-HHS R\&D contracts })_{t-1}$ & & & & & & $\begin{array}{c}0.064 \\
(0.024)\end{array}$ & & & \\
\hline $\ln (\text { Non-DoE R\&D contracts })_{t-1}$ & & & & & & & $\begin{array}{c}0.061 \\
(0.023)\end{array}$ & & \\
\hline $\ln (\text { Non-DHS R\&D contracts })_{t-1}$ & & & & & & & & $\begin{array}{c}0.060 \\
(0.023)\end{array}$ & \\
\hline $\ln (\text { Non-DoC R\&D contracts })_{t-1}$ & & & & & & & & & $\begin{array}{c}0.060 \\
(0.023)\end{array}$ \\
\hline $\ln (\text { Sales })_{t-2}$ & $\begin{array}{c}0.350 \\
(0.016)\end{array}$ & $\begin{array}{c}0.352 \\
(0.017)\end{array}$ & $\begin{array}{c}0.347 \\
(0.017)\end{array}$ & $\begin{array}{c}0.349 \\
(0.016)\end{array}$ & $\begin{array}{c}0.349 \\
(0.016)\end{array}$ & $\begin{array}{c}0.349 \\
(0.016)\end{array}$ & $\begin{array}{c}0.349 \\
(0.016)\end{array}$ & $\begin{array}{c}0.349 \\
(0.016)\end{array}$ & $\begin{array}{c}0.349 \\
(0.016)\end{array}$ \\
\hline Sample years & $1980-2015$ & $1980-2015$ & $1980-2015$ & $1980-2015$ & $1980-2015$ & $1980-2015$ & $1980-2015$ & $1980-2015$ & $1980-2015$ \\
\hline Firm fixed effects & Yes & Yes & Yes & Yes & Yes & Yes & Yes & Yes & Yes \\
\hline Year fixed effects & Yes & Yes & Yes & Yes & Yes & Yes & Yes & Yes & Yes \\
\hline Weak identif. (Kleibergen-Paap) & 96.13 & 29.38 & 38.32 & 103.87 & 104.13 & 96.88 & 101.96 & 101.84 & 102.94 \\
\hline Firms & 3,768 & 3,774 & 3,772 & 3,768 & 3,767 & 3,769 & 3,767 & 3,767 & 3,767 \\
\hline Observations & 40,430 & 40,649 & 40,518 & 40,447 & 40,414 & 40,439 & 40,429 & 40,417 & 40,413 \\
\hline Adjusted R-squared & 0.121 & -0.339 & -0.056 & 0.121 & 0.122 & 0.119 & 0.121 & 0.122 & 0.122 \\
\hline
\end{tabular}

Notes: This table presents the robustness of estimation results for the effect of R\&D contracts on firm-financed R\&D expenditures to excluding contracts from certain agencies. Columns 1-9 present the second stage of 2SLS, where $R \& D$ contracts are instrumented using Industry R\&D funding. Standard errors (in parentheses) are clustered at the firm level. 
Table G22: Publications Equation Excluding Agencies

\begin{tabular}{|c|c|c|c|c|c|c|c|c|c|}
\hline & $(1)$ & $(2)$ & $(3)$ & $(4)$ & (5) & $(6)$ & $(7)$ & $(8)$ & (9) \\
\hline & \multicolumn{9}{|c|}{$\ln$ (Publications) } \\
\hline & $\begin{array}{c}\text { Top } 7 \\
\text { Agencies } \\
\end{array}$ & $\begin{array}{c}\text { Other } \\
\text { Agencies }\end{array}$ & $\begin{array}{l}\text { Excl. } \\
\text { DoD }\end{array}$ & $\begin{array}{l}\text { Excl. } \\
\text { NASA }\end{array}$ & $\begin{array}{l}\text { Excl. } \\
\text { DoT }\end{array}$ & $\begin{array}{l}\text { Excl. } \\
\text { HHS }\end{array}$ & $\begin{array}{l}\text { Excl. } \\
\text { DoE }\end{array}$ & $\begin{array}{l}\text { Excl. } \\
\text { DHS }\end{array}$ & $\begin{array}{l}\text { Excl. } \\
\text { DoC }\end{array}$ \\
\hline $\ln (\text { Top } 7 \text { R\&D contracts })_{t-3}$ & $\begin{array}{c}0.036 \\
(0.019)\end{array}$ & & & & & & & & \\
\hline $\ln (\text { Other R\&D contracts })_{t-3}$ & & $\begin{array}{c}0.284 \\
(0.137)\end{array}$ & & & & & & & \\
\hline $\ln (\text { Non-DoD R\&D contracts })_{t-3}$ & & & $\begin{array}{c}0.118 \\
(0.058)\end{array}$ & & & & & & \\
\hline $\ln (\text { Non-NASA R\&D contracts })_{t-3}$ & & & & $\begin{array}{c}0.036 \\
(0.018)\end{array}$ & & & & & \\
\hline $\ln (\text { Non-DoT R\&D contracts })_{t-3}$ & & & & & $\begin{array}{c}0.035 \\
(0.018)\end{array}$ & & & & \\
\hline $\ln (\text { Non-HHS R\&D contracts) })_{t-3}$ & & & & & & $\begin{array}{c}0.039 \\
(0.019)\end{array}$ & & & \\
\hline $\ln (\text { Non-DoE R\&D contracts })_{t-3}$ & & & & & & & $\begin{array}{c}0.035 \\
(0.018)\end{array}$ & & \\
\hline $\ln (\text { Non-DHS R\&D contracts })_{t-3}$ & & & & & & & & $\begin{array}{c}0.035 \\
(0.018)\end{array}$ & \\
\hline $\ln (\text { Non-DoC R\&D contracts })_{t-3}$ & & & & & & & & & $\begin{array}{c}0.035 \\
(0.018)\end{array}$ \\
\hline $\ln (\mathrm{R} \& \mathrm{D} \text { stock })_{t-3}$ & $\begin{array}{c}0.114 \\
(0.010) \\
\end{array}$ & $\begin{array}{c}0.126 \\
(0.013) \\
\end{array}$ & $\begin{array}{c}0.119 \\
(0.011) \\
\end{array}$ & $\begin{array}{c}0.114 \\
(0.010)\end{array}$ & $\begin{array}{c}0.114 \\
(0.010)\end{array}$ & $\begin{array}{c}0.114 \\
(0.011)\end{array}$ & $\begin{array}{c}0.114 \\
(0.010)\end{array}$ & $\begin{array}{c}0.114 \\
(0.010)\end{array}$ & $\begin{array}{c}0.114 \\
(0.010)\end{array}$ \\
\hline Sample years & $1980-2015$ & $1980-2015$ & $1980-2015$ & $1980-2015$ & $1980-2015$ & $1980-2015$ & $1980-2015$ & $1980-2015$ & $1980-2015$ \\
\hline Firm fixed effects & Yes & Yes & Yes & Yes & Yes & Yes & Yes & Yes & Yes \\
\hline Year fixed effects & Yes & Yes & Yes & Yes & Yes & Yes & Yes & Yes & Yes \\
\hline Weak identif. (Kleibergen-Paap) & 93.65 & 29.84 & 39.19 & 103.24 & 101.81 & 93.49 & 99.90 & 99.97 & 100.94 \\
\hline Firms & 3,580 & 3,584 & 3,584 & 3,580 & 3,580 & 3,580 & 3,580 & 3,580 & 3,580 \\
\hline Observations & 41,053 & 41,221 & 41,111 & 41,076 & 41,046 & 41,061 & 41,060 & 41,049 & 41,047 \\
\hline Adjusted R-squared & 0.015 & -0.385 & -0.102 & 0.015 & 0.015 & 0.013 & 0.016 & 0.015 & 0.015 \\
\hline
\end{tabular}

Notes: This table presents the robustness of estimation results for the effect of R\&D contracts on corporate publications to excluding contracts from certain agencies. Columns 1-9 present the second stage of 2SLS, where $R \& D$ contracts are instrumented using Industry R\&D funding. Standard errors (in parentheses) are clustered at the firm level. 
Table G23: Patents Equation Excluding Agencies

\begin{tabular}{|c|c|c|c|c|c|c|c|c|c|}
\hline & (1) & $(2)$ & (3) & (4) & $\begin{array}{c}(5) \\
\ln (\text { Patents })\end{array}$ & (6) & (7) & (8) & (9) \\
\hline & $\begin{array}{c}\text { Top } 7 \\
\text { Agencies }\end{array}$ & $\begin{array}{c}\text { Other } \\
\text { Agencies }\end{array}$ & $\begin{array}{l}\text { Excl. } \\
\text { DoD }\end{array}$ & $\begin{array}{l}\text { Excl. } \\
\text { NASA }\end{array}$ & $\begin{array}{l}\text { Excl. } \\
\text { DoT }\end{array}$ & $\begin{array}{l}\text { Excl. } \\
\text { HHS }\end{array}$ & $\begin{array}{l}\text { Excl. } \\
\text { DoE }\end{array}$ & $\begin{array}{l}\text { Excl. } \\
\text { DHS }\end{array}$ & $\begin{array}{l}\text { Excl. } \\
\text { DoC }\end{array}$ \\
\hline $\ln (\text { Top } 7 \text { R\&D contracts })_{t-3}$ & $\begin{array}{l}-0.042 \\
(0.024)\end{array}$ & & & & & & & & \\
\hline $\ln (\text { Other R\&D contracts })_{t-3}$ & & $\begin{array}{l}-0.289 \\
(0.175)\end{array}$ & & & & & & & \\
\hline $\ln (\text { Non-DoD R\&D contracts })_{t-3}$ & & & $\begin{array}{l}-0.125 \\
(0.078)\end{array}$ & & & & & & \\
\hline $\ln$ (Non-NASA R\&D contracts) $_{t-3}$ & & & & $\begin{array}{l}-0.042 \\
(0.024)\end{array}$ & & & & & \\
\hline $\ln (\text { Non-DoT R\&D contracts })_{t-3}$ & & & & & $\begin{array}{l}-0.040 \\
(0.023)\end{array}$ & & & & \\
\hline $\ln (\text { Non-HHS R\&D contracts })_{t-3}$ & & & & & & $\begin{array}{l}-0.042 \\
(0.024)\end{array}$ & & & \\
\hline $\ln (\text { Non-DoE R\&D contracts })_{t-3}$ & & & & & & & $\begin{array}{c}-0.041 \\
(0.023)\end{array}$ & & \\
\hline $\ln (\text { Non-DHS R\&D contracts })_{t-3}$ & & & & & & & & $\begin{array}{l}-0.040 \\
(0.023)\end{array}$ & \\
\hline $\ln (\text { Non-DoC R\&D contracts })_{t-3}$ & & & & & & & & & $\begin{array}{c}-0.040 \\
(0.023)\end{array}$ \\
\hline $\ln (\mathrm{R} \& \mathrm{D} \text { stock })_{t-3}$ & $\begin{array}{c}0.242 \\
(0.015)\end{array}$ & $\begin{array}{c}0.230 \\
(0.017)\end{array}$ & $\begin{array}{c}0.237 \\
(0.016)\end{array}$ & $\begin{array}{c}0.241 \\
(0.015)\end{array}$ & $\begin{array}{c}0.241 \\
(0.015)\end{array}$ & $\begin{array}{c}0.241 \\
(0.015)\end{array}$ & $\begin{array}{c}0.241 \\
(0.015)\end{array}$ & $\begin{array}{c}0.241 \\
(0.015)\end{array}$ & $\begin{array}{c}0.241 \\
(0.015)\end{array}$ \\
\hline Sample years & $1980-2015$ & $1980-2015$ & $1980-2015$ & $1980-2015$ & $1980-2015$ & $1980-2015$ & $1980-2015$ & $1980-2015$ & $1980-2015$ \\
\hline Firm fixed effects & Yes & Yes & Yes & Yes & Yes & Yes & Yes & Yes & Yes \\
\hline Year fixed effects & Yes & Yes & Yes & Yes & Yes & Yes & Yes & Yes & Yes \\
\hline Weak identif. (Kleibergen-Paap) & 93.65 & 29.84 & 39.19 & 103.24 & 101.81 & 93.49 & 99.90 & 99.97 & 100.94 \\
\hline Firms & 3,580 & 3,584 & 3,584 & 3,580 & 3,580 & 3,580 & 3,580 & 3,580 & 3,580 \\
\hline Observations & 41,053 & 41,221 & 41,111 & 41,076 & 41,046 & 41,061 & 41,060 & 41,049 & 41,047 \\
\hline Adjusted R-squared & 0.046 & -0.233 & -0.049 & 0.043 & 0.046 & 0.043 & 0.045 & 0.045 & 0.046 \\
\hline
\end{tabular}

Notes: This table presents the robustness of estimation results for the effect of R\&D contracts on corporate patents to excluding contracts from certain agencies. Columns 1-9 present the second stage of 2SLS, where R\&D contracts are instrumented using Industry RES funding. Standard errors (in parentheses) are clustered at the firm level. 


\section{G.3 Other Procurement Shocks}

Table G24 presents robustness of the estimation results for the effect of R\&D contracts on publications using three alternative procurement shocks. We exploit the Cold War shock as a quasi-natural experiment for exogenous changes in government procurement from various industries. In the first stage reported in Column 1, we predict $R \& D$ contracts awarded to a focal firm using our instrument and obtain an F statistic of 103. In the second stage reported in Column 4, we regress Publications against the predicted $R \& D$ contracts. Because this instrument does not vary over time, we report pooled estimates and rely on pre-sample information regarding $R \& D$ expenditures to replace the unobservable firm fixed effect (similar to Blundell et al., 1999). The coefficient estimate indicates a positive causal effect of R\&D contracts on corporate publications ( $p$-value $<0.01$ ).

The estimate is substantially larger than the estimates from the other instrumental variables, for three reasons. The set of firms differs across approaches. ${ }^{76}$ Our other instruments may not fully resolve the downward bias in OLS because they rely on time-invariant exposure shares that could still be correlated with firm-specific, time-invariant heterogeneity. Alternatively, the Cold War instrument may not fully remove time-invariant firm heterogeneity using the pre-sample mean, making it even more sensitive to the temporal reallocation of contracts away from innovating firms.

Another way to mitigate the concern that the Cold War shock could suffer from endogeneityif strategic defense investments such as the Star Wars program led to the collapse of the Soviet Union - is to examine two alternative shocks. First, we use changes in procurement that were triggered by the terrorist attacks of September 11, 2001. Government procurement contracts were reallocated to support Operation Iraqi Freedom, Operation Enduring Freedom, and other military campaigns that were part of the new Global War on Terrorism. Second, we use changes in procurement that resulted from federal efforts to manage the financial crisis during the Great Recession of 2007-2008. Government procurement contracts were reallocated to support the hard-hit auto and aircraft industries. Table G24 shows that the effect of RED contracts on publications is robust to instrumenting for the endogenous R\&D contracts using either the Global War on Terrorism shock or the Financial Crisis shock. ${ }^{77}$

\section{G.4 Alternative Specifications}

One concern may be that our choice of regression model (OLS) and data transformation (taking the natural logarithm of publications or patents plus one) could be inappropriate, given that Publications and Patents are over-dispersed count variables. Columns 1 and 4 in Table G25 present estimations using Poisson pseudo-maximum likelihood regressions. Consistent with our OLS results, we find that $R E B D$ contracts have positive relationships with publications and patents ( $\mathrm{p}$-value $<0.05)$. We also present OLS and 2SLS estimations where we use an inverse hyperbolic sine transformation. ${ }^{78}$ Consistent with previous results, Columns 3 and 6 in Table G25 show that R\&D contracts have a positive effect on publications $(\mathrm{p}$-value $=0.055)$, but not on patents. Moreover, the coefficient estimate on $R \mathscr{E} D$ contracts for the publication equation is close in size to our main specification in Table 5.

\footnotetext{
${ }^{76}$ The analysis sample in Column 4 is restricted to firms for which we can calculate pre-sample mean publications during 1980-1988 and exposure to sales from various industries during 1982-1985. The actual regressions use data for 1995-2015. The range in coefficient estimates likely reflects the changing composition of our sample over a very long panel, with Cold War-era firms being more likely than newer firms to rely on (or respond to) guaranteed public demand.

${ }^{77}$ Table G24 uses the pre-sample mean publications calculated for the original Cold War shock (i.e., during 19801988), but results hold for alternative pre-sample periods, such as 1980-1990 or 1980-1995.

${ }^{78}$ The inverse hyperbolic sine is calculated as $\operatorname{asinh}(x)=\ln \left(x+\sqrt{x^{2}+1}\right)$.
} 
Table G24: Other Procurement Shocks

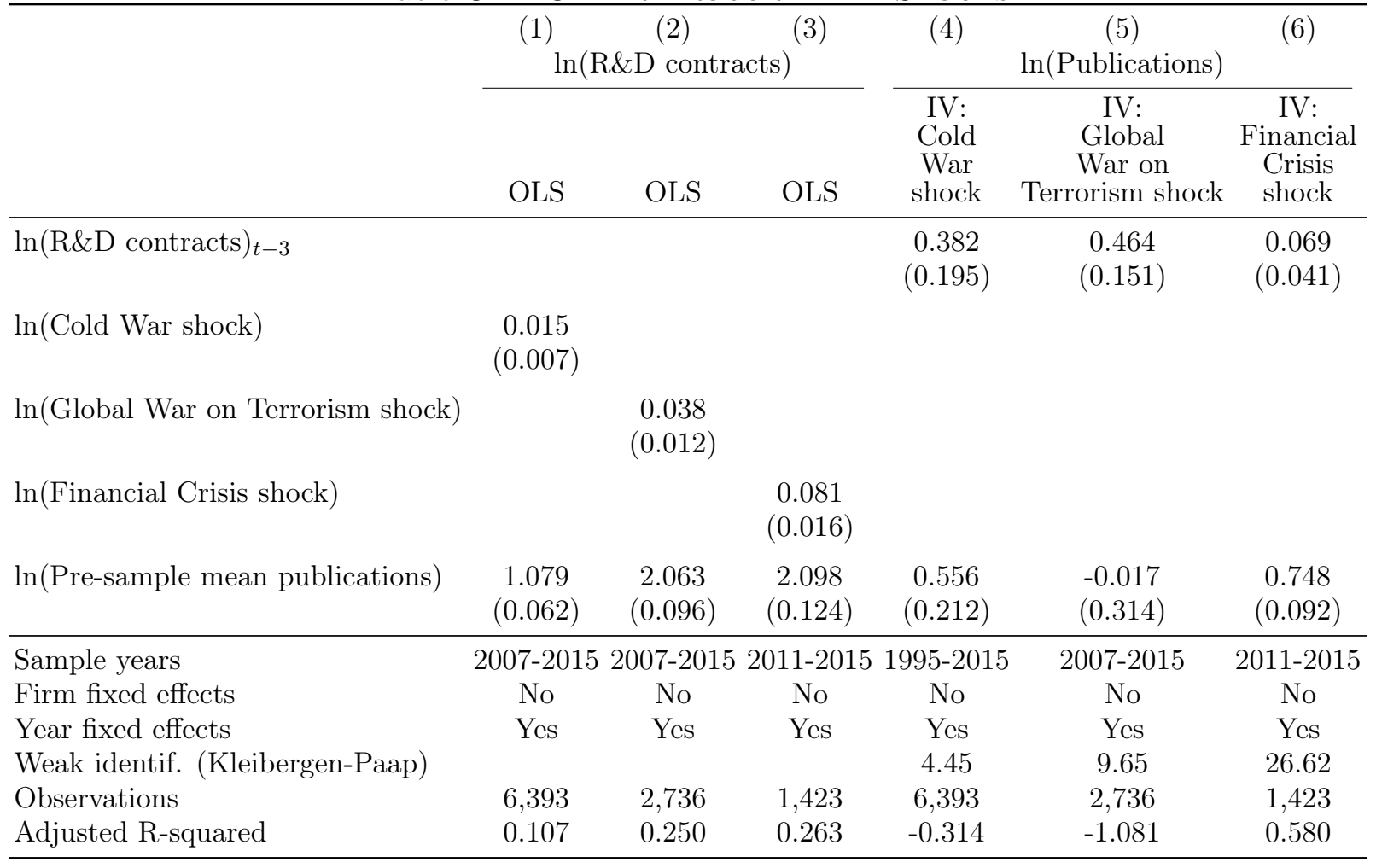

Notes: This table presents the robustness of estimation results for the effect of $\mathrm{R} \& \mathrm{D}$ contracts on publications to using alternative procurement shocks. The Global War on Terrorism shock is calculated using the difference in total contract values between pre- (2000) and post- (2004) periods for each SIC4 industry, weighted by the focal firm's sales exposure to different SIC4 industries during 1994-1997. The Financial Crisis shock is calculated using the difference in total contract values between pre- (2007) and post- (2008) periods for each SIC4 industry, weighted by the focal firm's sales exposure to different SIC4 industries during 2000-2003. The pre-sample mean publications are calculated using data from 1980-1988. Standard errors (in parentheses) are robust to arbitrary heteroskedasticity.

Table G25: Alternative Specifications

\begin{tabular}{|c|c|c|c|c|c|c|}
\hline & \multirow{3}{*}{$\begin{array}{c}(1) \\
\frac{\text { Publications }}{\text { Poisson }}\end{array}$} & \multirow{2}{*}{\multicolumn{2}{|c|}{$\begin{array}{c}(2) \\
\text { Inv. hyperbolic sine(Publications) }\end{array}$}} & \multirow{3}{*}{$\begin{array}{c}(4) \\
\text { Patents } \\
\text { Poisson }\end{array}$} & \multirow{2}{*}{\multicolumn{2}{|c|}{$\begin{array}{l}(5) \quad(6) \\
\text { Inv. hyperbolic sine(Patents) }\end{array}$}} \\
\hline & & & & & & \\
\hline & & OLS & $\begin{array}{c}\text { IV: } \\
\text { Ind. } R \& D \text { fund. }\end{array}$ & & OLS & $\begin{array}{c}\text { IV: } \\
\text { Ind. } R \& D \text { fund. }\end{array}$ \\
\hline $\ln (\mathrm{R} \& \mathrm{D} \text { contracts })_{t-3}$ & $\begin{array}{c}0.008 \\
(0.003)\end{array}$ & $\begin{array}{c}0.013 \\
(0.002)\end{array}$ & $\begin{array}{c}0.042 \\
(0.021)\end{array}$ & $\begin{array}{c}0.012 \\
(0.004)\end{array}$ & $\begin{array}{c}0.012 \\
(0.002)\end{array}$ & $\begin{array}{l}-0.044 \\
(0.027)\end{array}$ \\
\hline $\ln (\mathrm{R} \& \mathrm{D} \text { stock })_{t-3}$ & $\begin{array}{c}0.505 \\
(0.051)\end{array}$ & $\begin{array}{c}0.152 \\
(0.013)\end{array}$ & $\begin{array}{c}0.134 \\
(0.012)\end{array}$ & $\begin{array}{c}0.458 \\
(0.067)\end{array}$ & $\begin{array}{c}0.290 \\
(0.017)\end{array}$ & $\begin{array}{c}0.277 \\
(0.017)\end{array}$ \\
\hline Sample years & $1980-2015$ & $1980-2015$ & $1980-2015$ & $1980-2015$ & $1980-2015$ & $1980-2015$ \\
\hline Firm fixed effects & Yes & Yes & Yes & Yes & Yes & Yes \\
\hline Year fixed effects & Yes & Yes & Yes & Yes & Yes & Yes \\
\hline Weak identif. (Kleibergen-Paap) & & & 101.13 & & & 101.13 \\
\hline Firms & 2,387 & 3,632 & 3,580 & 3,166 & 3,632 & 3,580 \\
\hline Observations & 32,855 & 43,914 & 41,047 & 40,628 & 43,914 & 41,047 \\
\hline Adjusted R-squared & & 0.862 & 0.014 & & 0.838 & 0.044 \\
\hline
\end{tabular}

Notes: This table presents the robustness of estimation results for the relationship between R\&D contracts and publications and patents to using Poisson pseudo-maximum likelihood regression (Columns 1 and 4) or transforming publications and patents using an inverse hyperbolic sine (Columns 2-3 and 5-6). Standard errors (in parentheses) are clustered at the firm level. 


\section{G.5 Other Time Lags}

Our results are not sensitive to the specific lag structure assumed in our main specifications. Checking the sensitivity to lag structure is important because we do not observe the actual annual spending associated with contract awards. To construct our panel, we aggregate contract obligations, not actual outlays, at the firm-year level. Since multi-year procurement projects are common, the outlays may occur one, two, or more years after the original obligation date. Moreover, there is typically a lag between the year when the R\&D activity is conducted and the year when the paper is published or the patent is granted. Therefore, the specific lag structure between receiving an award and publishing a scholarly paper or receiving a patent grant is unclear. However, our results are robust to alternative time lags. Table G27 indicates that R\&D contracts have a positive effect on publications when using four- or five-year lags ( $\mathrm{p}$-value $<0.05$ ). The coefficient estimates are similar to Table 5. In unreported specifications, we find no effect of $R \& D$ contracts on patents when using four- or five-year lags.

Table G26: R\&D Expenditures Equation Using Different Time Lags

\begin{tabular}{|c|c|c|c|c|c|}
\hline & (1) & $(2)$ & $(3)$ & $(4)$ & $(5)$ \\
\hline & \multicolumn{5}{|c|}{$\ln (\mathrm{R} \& \mathrm{D}$ expenditures $)$} \\
\hline & $\begin{array}{c}\text { IV: Ind. } \\
\text { R\&D fund. } \\
(\mathrm{Lag}=1)\end{array}$ & $\begin{array}{l}\text { IV: Ind. } \\
\text { R\&D fund. } \\
(\mathrm{Lag}=2)\end{array}$ & $\begin{array}{c}\text { IV: Ind. } \\
\text { R\&D fund. } \\
(\mathrm{Lag}=3)\end{array}$ & $\begin{array}{c}\text { IV: Ind. } \\
\text { R\&D fund. } \\
(\mathrm{Lag}=4)\end{array}$ & $\begin{array}{l}\text { IV: Ind. } \\
\text { R\&D fund. } \\
(\mathrm{Lag}=5)\end{array}$ \\
\hline $\ln (\mathrm{R} \& \mathrm{D} \text { contracts })_{t-l a g}$ & $\begin{array}{c}0.060 \\
(0.023)\end{array}$ & $\begin{array}{c}0.065 \\
(0.024)\end{array}$ & $\begin{array}{c}0.052 \\
(0.025)\end{array}$ & $\begin{array}{c}0.039 \\
(0.025)\end{array}$ & $\begin{array}{c}0.037 \\
(0.024)\end{array}$ \\
\hline $\ln (\text { Sales })_{t-l a g-1}$ & $\begin{array}{c}0.349 \\
(0.016)\end{array}$ & $\begin{array}{c}0.305 \\
(0.017)\end{array}$ & $\begin{array}{c}0.269 \\
(0.017)\end{array}$ & $\begin{array}{c}0.235 \\
(0.018)\end{array}$ & $\begin{array}{c}0.207 \\
(0.018)\end{array}$ \\
\hline Sample years & $1980-2015$ & $1980-2015$ & $1980-2015$ & $1980-2015$ & $1980-2015$ \\
\hline Firm fixed effects & Yes & Yes & Yes & Yes & Yes \\
\hline Year fixed effects & Yes & Yes & Yes & Yes & Yes \\
\hline Weak identif. (Kleibergen-Paap) & 103.12 & 100.33 & 94.71 & 87.78 & 82.47 \\
\hline Firms & 3,767 & 3,423 & 3,130 & 2,844 & 2,613 \\
\hline Observations & 40,413 & 36,709 & 33,394 & 30,367 & 27,656 \\
\hline Adjusted R-squared & 0.122 & 0.082 & 0.068 & 0.057 & 0.041 \\
\hline
\end{tabular}

Notes: This table presents the robustness of estimation results for the relationship between R\&D contracts and RD expenditures to using alternative time lags. Standard errors (in parentheses) are clustered at the firm level.

\section{G.6 Related and Unrelated Research Areas}

A concern may be that R\&D contracts could crowd out unrelated research areas. For example, firms may respond to government $R \& D$ competitions by reducing their $R \& D$ activities in research areas that do not benefit directly from government spending. To test this possibility, we split the flow of corporate publications into related publications (i.e., those that acknowledge external support) and unrelated publications (i.e., those that do not). Similarly, we split the flow of corporate patents into those that self-cite at least one of the focal firms' related publications, and those that do not. As shown in Table G30, we do not find evidence to suggest that R\&D contracts crowd out unrelated research areas (although we cannot rule it out due to imprecise estimation results). 
Table G27: Publications Equation Using Different Time Lags

\begin{tabular}{|c|c|c|c|c|c|}
\hline & (1) & $(2)$ & $\begin{array}{c}(3) \\
\ln (\text { Publications })\end{array}$ & $(4)$ & $(5)$ \\
\hline & $\begin{array}{c}\text { IV: Ind. } \\
\text { R\&D fund. } \\
(\mathrm{Lag}=1)\end{array}$ & $\begin{array}{c}\text { IV: Ind. } \\
\text { R\&D fund. } \\
(\mathrm{Lag}=2)\end{array}$ & $\begin{array}{c}\text { IV: Ind. } \\
\text { R\&D fund. } \\
(\mathrm{Lag}=3)\end{array}$ & $\begin{array}{c}\text { IV: Ind. } \\
\text { R\&D fund. } \\
(\mathrm{Lag}=4)\end{array}$ & $\begin{array}{c}\text { IV: Ind. } \\
\text { R\&D fund. } \\
(\mathrm{Lag}=5)\end{array}$ \\
\hline $\ln (\mathrm{R} \& \mathrm{D} \text { contracts })_{t-l a g}$ & $\begin{array}{c}0.007 \\
(0.016)\end{array}$ & $\begin{array}{c}0.021 \\
(0.017)\end{array}$ & $\begin{array}{c}0.035 \\
(0.018)\end{array}$ & $\begin{array}{c}0.039 \\
(0.018)\end{array}$ & $\begin{array}{c}0.042 \\
(0.018)\end{array}$ \\
\hline $\ln (\mathrm{R} \& \mathrm{D} \text { stock })_{t-l a g}$ & $\begin{array}{c}0.150 \\
(0.010)\end{array}$ & $\begin{array}{c}0.135 \\
(0.010)\end{array}$ & $\begin{array}{c}0.114 \\
(0.010)\end{array}$ & $\begin{array}{c}0.102 \\
(0.011)\end{array}$ & $\begin{array}{c}0.087 \\
(0.011)\end{array}$ \\
\hline Sample years & $1980-2015$ & $1980-2015$ & $1980-2015$ & 1980-2015 & $1980-2015$ \\
\hline Firm fixed effects & Yes & Yes & Yes & Yes & Yes \\
\hline Year fixed effects & Yes & Yes & Yes & Yes & Yes \\
\hline Weak identif. (Kleibergen-Paap) & 111.92 & 107.79 & 101.13 & 96.01 & 92.24 \\
\hline Firms & 4,315 & 3,918 & 3,580 & 3,279 & 3,000 \\
\hline Observations & 49,638 & 45,116 & 41,047 & 37,346 & 33,962 \\
\hline Adjusted R-squared & 0.048 & 0.037 & 0.016 & 0.007 & -0.002 \\
\hline
\end{tabular}

Notes: This table presents the robustness of estimation results for the relationship between R\&D contracts and publications to using alternative time lags. Standard errors (in parentheses) are clustered at the firm level.

Table G28: Renowned Scientists Equation Using Different Time Lags

\begin{tabular}{|c|c|c|c|c|c|}
\hline & (1) & $(2)$ & $(3)$ & $(4)$ & $(5)$ \\
\hline & \multicolumn{5}{|c|}{$\ln$ (Renowned scientists) } \\
\hline & $\begin{array}{c}\text { IV: Ind. } \\
\text { R\&D fund. } \\
(\mathrm{Lag}=1)\end{array}$ & $\begin{array}{c}\text { IV: Ind. } \\
\text { R\&D fund. } \\
(\mathrm{Lag}=2)\end{array}$ & $\begin{array}{c}\text { IV: Ind. } \\
\text { R\&D fund. } \\
(\mathrm{Lag}=3)\end{array}$ & $\begin{array}{c}\text { IV: Ind. } \\
\text { R\&D fund. } \\
(\mathrm{Lag}=4)\end{array}$ & $\begin{array}{l}\text { IV: Ind. } \\
\text { R\&D fund. } \\
(\mathrm{Lag}=5)\end{array}$ \\
\hline $\ln (\mathrm{R} \& \mathrm{D} \text { contracts })_{t-l a g}$ & $\begin{array}{c}0.023 \\
(0.009)\end{array}$ & $\begin{array}{c}0.019 \\
(0.009)\end{array}$ & $\begin{array}{c}0.012 \\
(0.009)\end{array}$ & $\begin{array}{c}0.003 \\
(0.009)\end{array}$ & $\begin{array}{c}0.039 \\
(0.025)\end{array}$ \\
\hline $\ln (\mathrm{R} \& \mathrm{D} \text { stock })_{t-l a g}$ & $\begin{array}{c}0.040 \\
(0.006)\end{array}$ & $\begin{array}{c}0.034 \\
(0.006)\end{array}$ & $\begin{array}{c}0.032 \\
(0.004)\end{array}$ & $\begin{array}{c}0.026 \\
(0.006)\end{array}$ & $\begin{array}{c}0.189 \\
(0.020)\end{array}$ \\
\hline Sample years & $1980-2015$ & $1980-2015$ & $1980-2015$ & $1980-2015$ & $1980-2015$ \\
\hline Firm fixed effects & Yes & Yes & Yes & Yes & Yes \\
\hline Year fixed effects & Yes & Yes & Yes & Yes & Yes \\
\hline Weak identif. (Kleibergen-Paap) & 111.92 & 107.79 & 105.86 & 96.01 & 84.93 \\
\hline Firms & 4,315 & 3,918 & 3,675 & 3,279 & 2,800 \\
\hline Observations & 49,638 & 45,116 & 42,423 & 37,346 & 30,390 \\
\hline Adjusted R-squared & -0.006 & -0.004 & 0.007 & 0.005 & 0.017 \\
\hline
\end{tabular}

Notes: This table presents the robustness of estimation results for the relationship between R\&D contracts and renowned scientific human capital to using alternative time lags. Standard errors (in parentheses) are clustered at the firm level. 
Table G29: Patents Equation Using Different Time Lags

\begin{tabular}{|c|c|c|c|c|c|}
\hline & (1) & $(2)$ & $\begin{array}{c}(3) \\
\ln (\text { Patents })\end{array}$ & (4) & (5) \\
\hline & $\begin{array}{c}\text { IV: Ind. } \\
\text { R\&D fund. } \\
(\mathrm{Lag}=1)\end{array}$ & $\begin{array}{c}\text { IV: Ind. } \\
\text { R\&D fund. } \\
(\mathrm{Lag}=2)\end{array}$ & $\begin{array}{c}\text { IV: Ind. } \\
\text { R\&D fund. } \\
(\mathrm{Lag}=3)\end{array}$ & $\begin{array}{c}\text { IV: Ind. } \\
\text { R\&D fund. } \\
(\mathrm{Lag}=4)\end{array}$ & $\begin{array}{c}\text { IV: Ind. } \\
\text { R\&D fund. } \\
(\mathrm{Lag}=5)\end{array}$ \\
\hline $\ln (\mathrm{R} \& \mathrm{D} \text { contracts })_{t-l a g}$ & $\begin{array}{l}-0.060 \\
(0.023)\end{array}$ & $\begin{array}{l}-0.051 \\
(0.022)\end{array}$ & $\begin{array}{l}-0.040 \\
(0.023)\end{array}$ & $\begin{array}{l}-0.007 \\
(0.023)\end{array}$ & $\begin{array}{c}0.015 \\
(0.024)\end{array}$ \\
\hline $\ln (\mathrm{R} \& \mathrm{D} \text { stock })_{t-l a g}$ & $\begin{array}{c}0.286 \\
(0.015)\end{array}$ & $\begin{array}{c}0.266 \\
(0.015)\end{array}$ & $\begin{array}{c}0.241 \\
(0.015)\end{array}$ & $\begin{array}{c}0.214 \\
(0.015)\end{array}$ & $\begin{array}{c}0.188 \\
(0.015)\end{array}$ \\
\hline Sample years & $1980-2015$ & $1980-2015$ & $1980-2015$ & $1980-2015$ & $1980-2015$ \\
\hline Firm fixed effects & Yes & Yes & Yes & Yes & Yes \\
\hline Year fixed effects & Yes & Yes & Yes & Yes & Yes \\
\hline Weak identif. (Kleibergen-Paap) & 111.92 & 107.79 & 101.13 & 96.01 & 92.24 \\
\hline Firms & 4,315 & 3,918 & 3,580 & 3,279 & 3,000 \\
\hline Observations & 49,638 & 45,116 & 41,047 & 37,346 & 33,962 \\
\hline Adjusted R-squared & 0.050 & 0.048 & 0.046 & 0.053 & 0.044 \\
\hline
\end{tabular}

Notes: This table presents the robustness of estimation results for the relationship between R\&D contracts and patents to using alternative time lags. Standard errors (in parentheses) are clustered at the firm level.

Table G30: Unrelated Research Areas

\begin{tabular}{|c|c|c|c|c|c|c|c|c|}
\hline & (1) & $(2)$ & $(3)$ & $(4)$ & \multirow{2}{*}{\multicolumn{2}{|c|}{$\begin{array}{c}(5) \\
\ln (\text { Related patents })\end{array}$}} & \multirow{2}{*}{\multicolumn{2}{|c|}{$\begin{array}{cc}(7) & (8) \\
\ln (\text { Unrelated patents })\end{array}$}} \\
\hline & \multicolumn{2}{|c|}{$\ln$ (Related publications) } & \multicolumn{2}{|c|}{$\ln$ (Unrelated publications) } & & & & \\
\hline & OLS & $\begin{array}{c}\text { IV: } \\
\text { Ind. } \\
\text { R\&D fund. }\end{array}$ & OLS & $\begin{array}{c}\text { IV: } \\
\text { Ind. } \\
\text { R\&D fund. }\end{array}$ & OLS & $\begin{array}{c}\text { IV: } \\
\text { Ind. } \\
\text { R\&D fund. }\end{array}$ & OLS & $\begin{array}{c}\text { IV: } \\
\text { Ind. } \\
\text { R\&D fund. }\end{array}$ \\
\hline $\ln (\mathrm{R} \& \mathrm{D} \text { contracts })_{t-3}$ & $\begin{array}{c}0.008 \\
(0.002)\end{array}$ & $\begin{array}{c}0.024 \\
(0.013)\end{array}$ & $\begin{array}{c}0.009 \\
(0.002)\end{array}$ & $\begin{array}{c}0.023 \\
(0.018)\end{array}$ & $\begin{array}{c}0.000 \\
(0.001)\end{array}$ & $\begin{array}{c}0.002 \\
(0.003)\end{array}$ & $\begin{array}{c}0.010 \\
(0.002)\end{array}$ & $\begin{array}{l}-0.041 \\
(0.023)\end{array}$ \\
\hline $\ln (\mathrm{R} \& \mathrm{D} \text { stock })_{t-3}$ & $\begin{array}{c}0.060 \\
(0.010)\end{array}$ & $\begin{array}{c}0.049 \\
(0.009)\end{array}$ & $\begin{array}{c}0.120 \\
(0.011)\end{array}$ & $\begin{array}{c}0.105 \\
(0.010)\end{array}$ & $\begin{array}{c}0.007 \\
(0.005)\end{array}$ & $\begin{array}{c}0.005 \\
(0.004)\end{array}$ & $\begin{array}{c}0.251 \\
(0.015)\end{array}$ & $\begin{array}{c}0.240 \\
(0.015)\end{array}$ \\
\hline Sample years & $1980-2015$ & $1980-2015$ & $1980-2015$ & $1980-2015$ & $1980-2015$ & $1980-2015$ & $1980-2015$ & $1980-2015$ \\
\hline Firm fixed effects & Yes & Yes & Yes & Yes & Yes & Yes & Yes & Yes \\
\hline Year fixed effects & Yes & Yes & Yes & Yes & Yes & Yes & Yes & Yes \\
\hline Weak identif. (Kleibergen-Paap) & & 101.13 & & 101.13 & & 101.13 & & 101.13 \\
\hline Firms & 3,632 & 3,580 & 3,632 & 3,580 & 3,632 & 3,580 & 3,632 & 3,580 \\
\hline Observations & 43,914 & 41,047 & 43,914 & 41,047 & 43,914 & 41,047 & 43,900 & 41,033 \\
\hline Adjusted R-squared & 0.593 & -0.006 & 0.866 & 0.019 & 0.309 & -0.001 & 0.847 & 0.044 \\
\hline
\end{tabular}

Notes: This table presents the robustness of estimation results for the relationship of R\&D contracts with publications and patents to considering related and unrelated research areas. Related publications acknowledge external support, while Unrelated publications do not. Related patents self-cite at least one of the focal firm's Related publications, while Unrelated patents do not. Standard errors (in parentheses) are clustered at the firm level. 


\section{G.7 Other Event Study Specifications}

Figure G4 presents the event study without additional controls for the level and percentage change in private demand.
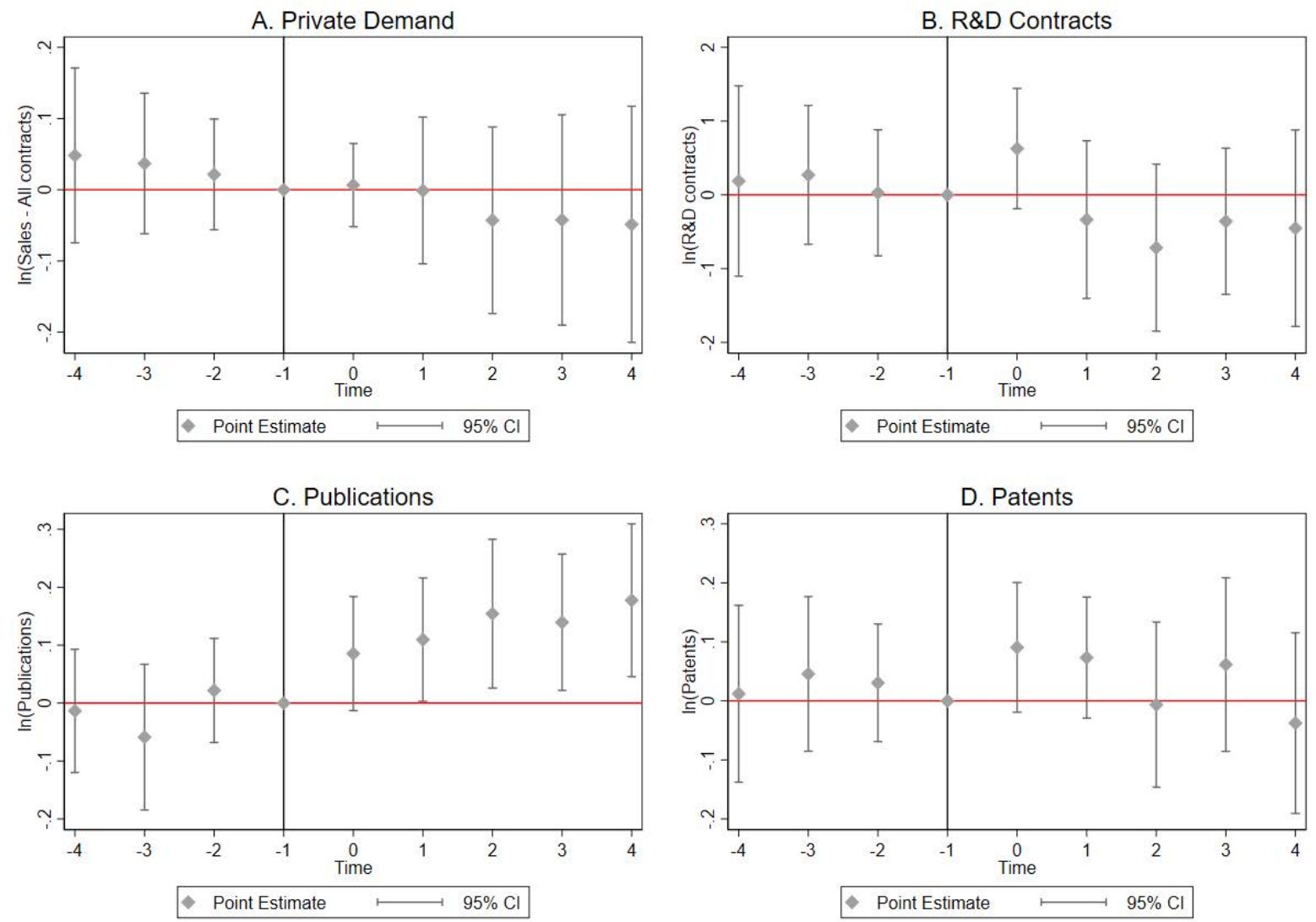

Figure G4: Event Study Without Additional Controls

This figure presents an event study around the end of the Cold War, estimated without using additional controls. All specifications use firm fixed effects and year fixed effects. All specifications are estimated using firms that have data for the entire 9-year period to control for changes in the composition of industries over time. Standard errors are clustered at the firm level. 


\section{G.8 Other Evidence on Guaranteed Demand}

Table G31 examines how the effect of R\&D contracts on upstream corporate R\&D varies with the awarding agency's ability to guarantee demand. In unreported specifications, we find similar results to Columns 1-4 when we instrument for the endogenous R\&D contracts using the Industry R\&D funding or the Agency RED budget instruments.

Table G31: Variation by Agency Guaranteed Demand

\begin{tabular}{|c|c|c|c|c|c|c|c|}
\hline & \multicolumn{7}{|c|}{$\ln$ (Publications) } \\
\hline & $\begin{array}{c}\text { IV: } \\
\text { Windfall- } \\
\text { predicted } \\
\text { R\&D budget }\end{array}$ & $\begin{array}{c}\text { IV: } \\
\text { Windfall- } \\
\text { predicted } \\
\text { R\&D budget }\end{array}$ & $\begin{array}{c}\text { IV: } \\
\text { Windfall- } \\
\text { predicted } \\
\text { R\&D budget }\end{array}$ & $\begin{array}{c}\text { IV: } \\
\text { Windfall- } \\
\text { predicted } \\
\text { R\&D budget }\end{array}$ & $\begin{array}{c}\text { IVs: } \\
\text { Windfall- } \\
\text { predicted } \\
\text { R\&D budget; } \\
\text { Agency } \\
\text { R\&D budget }\end{array}$ & $\begin{array}{c}\text { IVs: } \\
\text { Windfall- } \\
\text { predicted } \\
\text { R\&D budget; } \\
\text { Agency } \\
\text { R\&D budget }\end{array}$ & $\begin{array}{c}\text { IVs: } \\
\text { Windfall- } \\
\text { predicted } \\
\text {;\&D budget; } \\
\text { Agency } \\
\text { R\&D budget }\end{array}$ \\
\hline $\ln (\text { Air Force } R \& D \text { contracts })_{t-3}$ & $\begin{array}{c}0.152 \\
(0.072)\end{array}$ & & & & $\begin{array}{c}0.145 \\
(0.075)\end{array}$ & & \\
\hline $\ln (\text { Navy R\&D contracts })_{t-3}$ & & $\begin{array}{c}0.095 \\
(0.044)\end{array}$ & & & & $\begin{array}{c}0.092 \\
(0.047)\end{array}$ & \\
\hline $\ln (\text { Army R\&D contracts })_{t-3}$ & & & $\begin{array}{c}0.082 \\
(0.040)\end{array}$ & & & & $\begin{array}{c}0.080 \\
(0.043)\end{array}$ \\
\hline $\ln (\text { DARPA R\&D contracts })_{t-3}$ & & & & $\begin{array}{c}0.850 \\
(0.615)\end{array}$ & $\begin{array}{c}0.034 \\
(0.088)\end{array}$ & $\begin{array}{c}0.019 \\
(0.079)\end{array}$ & $\begin{array}{c}0.005 \\
(0.080)\end{array}$ \\
\hline $\ln (\mathrm{R} \& \mathrm{D} \text { stock })_{t-3}$ & $\begin{array}{c}0.115 \\
(0.011)\end{array}$ & $\begin{array}{c}0.113 \\
(0.011)\end{array}$ & $\begin{array}{c}0.114 \\
(0.011)\end{array}$ & $\begin{array}{c}0.134 \\
(0.019)\end{array}$ & $\begin{array}{c}0.116 \\
(0.011)\end{array}$ & $\begin{array}{c}0.113 \\
(0.011)\end{array}$ & $\begin{array}{c}0.114 \\
(0.011)\end{array}$ \\
\hline Sample years & $1980-2015$ & 1980-2015 & $1980-2015$ & $1980-2015$ & $1980-2015$ & $1980-2015$ & $1980-2015$ \\
\hline Firm fixed effects & Yes & Yes & Yes & Yes & Yes & Yes & Yes \\
\hline Year fixed effects & Yes & Yes & Yes & Yes & Yes & Yes & Yes \\
\hline Weak identif. (Kleibergen-Paap) & 26.93 & 44.58 & 48.32 & 3.63 & 9.74 & 11.77 & 9.17 \\
\hline Firms & 3,589 & 3,586 & 3,588 & 3,589 & 3,587 & 3,584 & 3,586 \\
\hline Observations & 41,271 & 41,265 & 41,231 & 41,298 & 41,248 & 41,242 & 41,208 \\
\hline Adjusted R-squared & -0.142 & -0.040 & -0.031 & -2.452 & -0.131 & -0.037 & -0.029 \\
\hline
\end{tabular}

Notes: This table presents results from estimating how the effect of R\&D contracts on publications varies by the awarding agency's ability to guarantee demand. All specifications present the second stage of 2SLS, where R\&D contracts from DoD subagencies are instrumented as noted. Standard errors (in parentheses) are clustered at the firm level. 


\section{G.9 Nonlinear Time Effects}

Table G32 presents the changing composition of government contracts allowing for nonlinear time effects.

Table G32: Nonlinear Time Effects

\begin{tabular}{|c|c|c|c|c|c|}
\hline & \multirow[t]{2}{*}{ (1) } & $(2)$ & \multirow[t]{2}{*}{ (3) } & \multirow{2}{*}{\multicolumn{2}{|c|}{$\begin{array}{cc}(4) & (5) \\
\text { Contract composition }\end{array}$}} \\
\hline & & Jontract value & & & \\
\hline & $\begin{array}{c}\ln (\text { All } \\
\text { contracts })\end{array}$ & $\begin{array}{c}\ln (\mathrm{R} \& \mathrm{D} \\
\text { contracts })\end{array}$ & $\begin{array}{l}\ln (\text { Comm. } \\
\text { contracts })\end{array}$ & $\begin{array}{l}\text { Share } \mathrm{R} \& \mathrm{D} / \\
\text { All contracts }\end{array}$ & $\begin{array}{l}\text { Share comm./ } \\
\text { All contracts }\end{array}$ \\
\hline Indicator for Decade $=1990 \mathrm{~s}$ & $\begin{array}{l}-0.039 \\
(0.133)\end{array}$ & $\begin{array}{l}-0.157 \\
(0.088)\end{array}$ & & $\begin{array}{c}0.029 \\
(0.018)\end{array}$ & \\
\hline Indicator for Decade $=2000 \mathrm{~s}$ & $\begin{array}{c}0.502 \\
(0.180)\end{array}$ & $\begin{array}{l}-0.103 \\
(0.129)\end{array}$ & $\begin{array}{l}2.403 \\
(0.105)\end{array}$ & $\begin{array}{c}0.003 \\
(0.020)\end{array}$ & $\begin{array}{c}0.200 \\
(0.023)\end{array}$ \\
\hline Indicator for Decade $=2010 \mathrm{~s}$ & $\begin{array}{c}0.510 \\
(0.214)\end{array}$ & $\begin{array}{l}-0.396 \\
(0.149)\end{array}$ & $\begin{array}{l}3.200 \\
(0.141)\end{array}$ & $\begin{array}{c}0.008 \\
(0.049)\end{array}$ & $\begin{array}{c}0.427 \\
(0.037)\end{array}$ \\
\hline $\ln (\mathrm{R} \& \mathrm{D} \text { stock })_{t-1}$ & $\begin{array}{c}0.482 \\
(0.054)\end{array}$ & $\begin{array}{c}0.137 \\
(0.034)\end{array}$ & $\begin{array}{c}0.480 \\
(0.057)\end{array}$ & $\begin{array}{l}-0.000 \\
(0.007)\end{array}$ & $\begin{array}{l}-0.036 \\
(0.019)\end{array}$ \\
\hline Sample years & $1980-2015$ & $1980-2015$ & 1995-2015 & $1980-2015$ & $1995-2015$ \\
\hline Firm fixed effects & Yes & Yes & Yes & Yes & Yes \\
\hline Firms & 4,367 & 4,370 & 3,657 & 2,129 & 1,711 \\
\hline Observations & 52,795 & 52,865 & 36,836 & 22,530 & 15,338 \\
\hline Adjusted R-squared & 0.738 & 0.658 & 0.686 & 0.007 & 0.003 \\
\hline
\end{tabular}

Notes: This table presents OLS estimates for changes in procurement contract value and composition over time, accounting for nonlinear time effects. Standard errors (in parentheses) are clustered at the firm level. 